\title{
Albendazole and Mebendazole as Anti-Parasitic and Anti-Cancer Agents: an Update
}

\author{
Jong-Yil Chai ${ }^{1,2, *} \mathbb{C}$, Bong-Kwang Jung ${ }^{1} \mathbb{1}$, Sung-Jong Hong ${ }^{3}$ (]) \\ 1/nstitute of Parasitic Diseases, Korea Association of Health Promotion, Seoul 07649, Korea; '2Department of Tropical Medicine and Parasitology, \\ Seoul National University College of Medicine, Seoul 03080, Korea; ${ }^{3}$ Department of Environmental Medical Biology, Chung-Ang University College \\ of Medicine, Seoul 06974, Korea
}

\begin{abstract}
The use of albendazole and mebendazole, i.e., benzimidazole broad-spectrum anthelmintics, in treatment of parasitic infections, as well as cancers, is briefly reviewed. These drugs are known to block the microtubule systems of parasites and mammalian cells leading to inhibition of glucose uptake and transport and finally cell death. Eventually they exhibit ovicidal, larvicidal, and vermicidal effects on parasites, and tumoricidal effects on hosts. Albendazole and mebendazole are most frequently prescribed for treatment of intestinal nematode infections (ascariasis, hookworm infections, trichuriasis, strongyloidiasis, and enterobiasis) and can also be used for intestinal tapeworm infections (taeniases and hymenolepiasis). However, these drugs also exhibit considerable therapeutic effects against tissue nematode/cestode infections (visceral, ocular, neural, and cutaneous larva migrans, anisakiasis, trichinosis, hepatic and intestinal capillariasis, angiostrongyliasis, gnathostomiasis, gongylonemiasis, thelaziasis, dracunculiasis, cerebral and subcutaneous cysticercosis, and echinococcosis). Albendazole is also used for treatment of filarial infections (lymphatic filariasis, onchocerciasis, loiasis, mansonellosis, and dirofilariasis) alone or in combination with other drugs, such as ivermectin or diethylcarbamazine. Albendazole was tried even for treatment of trematode (fascioliasis, clonorchiasis, opisthorchiasis, and intestinal fluke infections) and protozoan infections (giardiasis, vaginal trichomoniasis, cryptosporidiosis, and microsporidiosis). These drugs are generally safe with few side effects; however, when they are used for prolonged time (>14-28 days) or even only 1 time, liver toxicity and other side reactions may occur. In hookworms, Trichuris trichiura, possibly Ascaris lumbricoides, Wuchereria bancrofti, and Giardia sp., there are emerging issues of drug resistance. It is of particular note that albendazole and mebendazole have been repositioned as promising anti-cancer drugs. These drugs have been shown to be active in vitro and in vivo (animals) against liver, lung, ovary, prostate, colorectal, breast, head and neck cancers, and melanoma. Two clinical reports for albendazole and 2 case reports for mebendazole have revealed promising effects of these drugs in human patients having variable types of cancers. However, because of the toxicity of albendazole, for example, neutropenia due to myelosuppression, if high doses are used for a prolonged time, mebendazole is currently more popularly used than albendazole in anti-cancer clinical trials.
\end{abstract}

Key words: Albendazole, mebendazole, nematode, trematode, cestode, liver toxicity, drug resistance, anti-cancer activity, review

\section{INTRODUCTION}

Albendazole, methyl [5-(propylthio)-1H-benzimidazol-2-yl] carbamate, is a broad- spectrum anti-parasitic agent, first introduced in 1975 for treatment of liver flukes, tapeworms, lung and gastrointestinal nematodes in sheep and cattle [1]. It was subsequently approved for human use in 1982 [2,3]. Mebendazole, methyl 5-benzoyl-1H-benzimidazol-2-yl-carbamate, is

\footnotetext{
- Received 3 May 2021, revised 27 May 2021, accepted 27 May 2021.

*Corresponding author (cjy@snu.ac.kr)

(C) 2021, Korean Society for Parasitology and Tropical Medicine

This is an Open Access article distributed under the terms of the Creative Commons

Attribution Non-Commercial License (https://creativecommons.org/licenses/by-nc/4.0) which permits unrestricted non-commercial use, distribution, and reproduction in any

medium, provided the original work is properly cited.
}

also a broad-spectrum anthelmintic, applied first to human subjects in 1971 [4]. Both drugs are relatively insoluble in water and most organic solvents and poorly absorbed from the gastrointestinal tract unless administered with high-fat meals [5]. The absorption rate of oral albendazole and mebendazole in human intestine is about $1-5 \%$ [3]. It is assumed that these drugs act directly on luminal parasites in the gastrointestinal tract, and after first-pass in the intestinal wall and liver their metabolites are active against parasites in internal organs and tissues $[3,4]$. For example, albendazole sulfoxide, among 5 metabolites of albendazole detected in human urine, is considered the major metabolite responsible for the anthelmintic activity $[3,6]$. In mebendazole, 2 forms of metabolites are known in the plasma, i.e., aminometabolite and hydroxyme- 
tabolite, which are excreted in urine as decarboxylated forms [6]. Albendazole and mebendazole are known to block microtubule functions of parasites and mammalian cells through inhibition of polymerization of ß-tubulin into microtubules followed by inhibition of glucose uptake and transport which eventually lead parasites to be in shortage of glycogen [7].

Since albendazole and mebendazole were first used for treatment of several intestinal helminth species infecting humans $[2,4]$, numerous studies have been performed on their anthelmintic efficacies against a variety of nematodes, trematodes, cestodes, and even protozoans [1,3,5-12]. The examples of nematode infections included ascariasis, hookworm infections, trichuriasis, strongyloidiasis, enterobiasis, larva migrans (visceral, ocular, neural, and cutaneous), anisakiasis (anisakidosis), trichinosis, angiostrongyliasis (cerebral and abdominal), gnathostomiasis, capillariasis (hepatic and intestinal), thelaziasis, lymphatic filariasis, onchocerciasis, and dirofilariasis $[8,9]$. Trematode infections that can be treated with albendazole and/or mebendazole are fascioliasis, clonorchiasis, opisthorchiasis, and intestinal fluke infections [13-20]. Cestode diseases responsive to albendazole and/or mebendazole include cysticercosis, hydatidosis, and intestinal taeniases [21-25]. Protozoan diseases for which albendazole and/or mebendazole have been tried were giardiasis, vaginal trichomoniasis, cryptosporidiosis, and microsporidiosis, although the efficacies against some of these infections need to be further evaluated $[12,26-31]$.

Meanwhile, albendazole and mebendazole have been shown to suppress tumor growth in vitro and in vivo and thus have been repositioned as anti-cancer agents [32-35]. For example, albendazole induces oxidative stress promoting DNA fragmentation and triggering apoptosis and inducing death of breast cancer cells [33]. Mebendazole disrupts microtubule functions by preventing polymerization of tubulin in cancer cells, such as glioblastoma and melanoma, and leads to cell death [32]. In addition, mebendazole would synergize with a range of other anti-cancer drugs, including the existing ones [32].

Albendazole and mebendazole are generally safe without significant side effects when used in recommended doses just for 1-3 days $[2,4,9,13]$. However, when these drugs are used for prolonged periods to treat tissue helminthiases [36], cancers $[37,38]$, or even when they are used just for once as preventive chemotherapy for intestinal helminths [39], liver toxicity, allergic reactions, and rarely severe myelosuppression (in particular, neutropenia) may occur. In addition, the occurrence of drug resistance to albendazole and mebendazole with treatment failure was reported recently in hookworm infections, trichuriasis, ascariasis, and lymphatic filariasis [40-42] which has become a significant emerging issue.

The present study aimed to review briefly recent trends in use of albendazole and mebendazole not only as anti-parasitic agents but also as new promising anti-cancer agents. In addition, the increasing reports on the hepatotoxicity of these drugs as well as drug resistance in parasites are also briefly reviewed.

\section{INTESTINAL HELMINTHIASES}

\section{Ascariasis}

Among various species of intestinal nematodes infecting humans, Ascaris lumbricoides is the most highly susceptible parasite species to albendazole and mebendazole [1,8-10,42-44] (Table 1). The earliest clinical study in 1982 using albendazole (400 $\mathrm{mg}$ in a single dose) reported the cure rate (CR) (= egg negative conversion rate; NCR) to be $96 \%$, and the egg reduction rate (ERR) almost 100\% [2]. A reduced dose, i.e., $200 \mathrm{mg}$ in a single dose, was also found to be equally effective against A. lumbricoides infection showing $92.3 \% \mathrm{CR}$ and $98.3 \%$ ERR [8]. However, viewing from the drug efficacy and safety, the recommended dose of albendazole for $A$. lumbricoides has been set at $400 \mathrm{mg}$ single dose by World Health Organization (WHO) [45]. The therapeutic efficacy of albendazole against $A$. lumbricoides seems unchanged until recently (2017); it was reported to be $95.7-96.5 \%$ in CR and $98.5-99.7 \%$ in ERR $[42,43]$. Albendazole (400 mg single dose) was shown to be useful for short-term control (4 months) of ascariasis using mass drug administration (MDA) in schoolchildren in Yangon Region, Myanmar [46].

The effect of mebendazole against intestinal nematodes, including A. lumbricoides, was reported at an earlier time in 1971 from schoolchildren in Brazil using the dose of 100 or $200 \mathrm{mg}$ twice daily for 3-4 consecutive days or $100 \mathrm{mg}$ daily for 6 days [47]. The cure rate for ascariasis was 100\% [47]. However, these regimens (repeated doses for 3-6 days) were inconvenient especially for MDA. Therefore, reduced single doses were tried by various researchers [48-50]. The study using a 200 or $300 \mathrm{mg}$ single dose in Costa Rica reported 93-100\% cure rates of A. lumbricoides infection and almost 100\% ERR [48]. Another study in South Korea reported that a single dose of 200-300 
Table 1. Use of albendazole and mebendazole for treatment of intestinal helminth infections (nematodes and cestodes)

\begin{tabular}{|c|c|c|c|c|c|}
\hline Drug & Disease & Regimen & Cure rate (\%) & Egg reduction rate (\%) & References \\
\hline \multirow[t]{13}{*}{ Albendazole } & \multirow[t]{2}{*}{ Ascariasis } & 400 mg single ${ }^{a}$ & 81.8-100 & $87.0-100$ & {$[8,10,42,44]$} \\
\hline & & 200 mg single & 92.3 & 98.3 & {$[8]$} \\
\hline & Hookworm infections & 400 mg single ${ }^{a}$ & $72.0-96.0$ & $64.0-100$ & {$[8,10,42]$} \\
\hline & \multirow[t]{2}{*}{ Trichuriasis } & 400 mg single ${ }^{a}$ & $27.2-81.0$ & $0-99.0$ & {$[8,10,44]$} \\
\hline & & $400 \mathrm{mg} /$ day $\times 3$ days & 53.0 & $81.0-100$ & [10] \\
\hline & \multirow[t]{2}{*}{ Strongyloidiasis } & 400 mg single ${ }^{a}$ & 69.0 & NA & [10] \\
\hline & & 400 mg b.i.d. $\times 3$ days & $62.0-100$ & NA & {$[10,14]$} \\
\hline & \multirow[t]{2}{*}{ Enterobiasis } & 400 mg single ${ }^{a}$ & $98.1-100$ & NA & {$[13,62]$} \\
\hline & & $100-400$ mg single & $90.0-100$ & NA & [63] \\
\hline & \multirow[t]{2}{*}{ Taeniases } & $400 \mathrm{mg} /$ day $\times 3$ days & $75.7-100$ & NA & [50] \\
\hline & & 400 mg b.i.d. $\times 3$ days & $70.0-95.0$ & NA & {$[13,21]$} \\
\hline & \multirow[t]{2}{*}{ Hymenolepiasis } & $400 \mathrm{mg} /$ day $\times 3$ days & $28.5-100$ & NA & [50] \\
\hline & & 400 mg b.i.d. $\times 2$ days & 66.7 & NA & [13] \\
\hline \multirow[t]{13}{*}{ Mebendazole } & \multirow[t]{3}{*}{ Ascariasis } & 500 mg single ${ }^{a}$ & 95.0 & $96.0-100$ & [10] \\
\hline & & $100-300$ mg single & $89.7-96.7$ & 98.6-99.9 & [49] \\
\hline & & 100 mg b.i.d. $\times 3$ days & $92.0-100$ & $91.0-100$ & {$[10,49]$} \\
\hline & \multirow[t]{2}{*}{ Hookworm infections } & $500 \mathrm{mg}$ single & $15.0-17.6$ & $0-98.0$ & {$[10,44]$} \\
\hline & & 100 mg b.i.d. $\times 3$ days ${ }^{a}$ & $52.0-80.0$ & $41.0-100$ & {$[8,10]$} \\
\hline & \multirow[t]{2}{*}{ Trichuriasis } & 500 mg single & $27.9-36.0$ & $66.0-93.0$ & {$[10,44]$} \\
\hline & & 100 mg b.i.d. $\times 3$ days ${ }^{a}$ & $33.7-80.0$ & 67.1-99.0 & {$[10,58]$} \\
\hline & \multirow[t]{3}{*}{ Enterobiasis } & 100 mg single ${ }^{a}$ & $90.0-100$ & NA & [8] \\
\hline & & 25-200 mg single & $62.0-100$ & NA & {$[4]$} \\
\hline & & $100-400$ mg single & $90.0-100$ & NA & [63] \\
\hline & \multirow[t]{2}{*}{ Taeniases } & 500 mg single & 50.0 & NA & [23] \\
\hline & & $500 \mathrm{mg} /$ day $\times 3$ days & 100.0 & NA & [23] \\
\hline & Hymenolepiasis & 100 mg t.i.d. $\times 3$ days & $18-40$ & NA & [71] \\
\hline
\end{tabular}

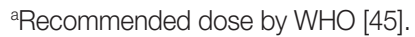

NA, not applicable.

mg revealed 93.8-96.7\% CR and 98.6-99.9\% ERR [49]. A lower dose, $100 \mathrm{mg}$ once, was almost equally effective as 200-300 $\mathrm{mg}$, showing $89.7 \% \mathrm{CR}$ and $98.6 \%$ ERR [49]. On the other hand, a trial using $500 \mathrm{mg}$ single dose of mebendazole was reported to be highly effective for ascariasis with $93.4 \% \mathrm{CR}$ and 99.0\% ERR [50]. In view of the efficacy and safety, the recommended dose of mebendazole for ascariasis has been set at $500 \mathrm{mg}$ single dose by WHO [45]. The therapeutic efficacy of mebendazole against $A$. lumbricoides seems unchanged until recently (2017); it was reported to be $96.2 \%$ in CR and $98.0 \%$ in ERR [43].

\section{Hookworm infections}

The use of albendazole for treatment of hookworm infections in humans, i.e., Ancylostoma duodenale and Necator americanus in most cases, started in the early 1980 s $[2,51,52]$. Pene et al. $[2,51]$ reported that the CR and ERR using $400 \mathrm{mg}$ single dose were $80.7-94.3 \%$ and $97.0 \%$, respectively, whereas Soula and Siopathis [52] reported lower effects, $74.0 \%$ and $97.5 \%$, respectively. Thereafter, until March 1999, at least 68 articles reported the efficacy of albendazole (400 $\mathrm{mg}$ single dose; the recommended dose by WHO [45]) against hookworm infections (A. duodenale or N. americanus), with CR ranging from 33.3 to $100 \%$ (av. $77.7 \%$ ), and ERR from 29.6 to $100 \%$ [53]. The efficacy was markedly different between the species of hookworms and between adults and children age groups. The average CR for A. duodenale was higher (91.8\%) than that for $\mathrm{N}$. americanus (75.0\%), and those for adults and children in $A$. duodenale were similar, $91.7 \%$ and $90.8 \%$, respectively, whereas those for adults and children in N. americanus were $80.9 \%$ and $67.0 \%$, respectively [53]. These results represent lower efficacy of albendazole in treatment of $\mathrm{N}$. americanus hookworm infections especially in children. Similar efficacies were reported after 2000, for example, Keiser and Utzinger [10] reported that 
the CR of albendazole for hookworms using $400 \mathrm{mg}$ single dose was $72.0 \%$ and the ERR was $64.0-100 \%$ (Table 1), and Moser et al. [43] reported 79.5\% CR and 89.6\% ERR.

Mebendazole showed poor efficacy for hookworms if used $500 \mathrm{mg}$ only 1 time. Keiser and Utzinger [10] and Soukhathammavong et al. [44] reported the CRs of $500 \mathrm{mg}$ single dose of mebendazole to be $15.0 \%$ and $17.6 \%$ and ERR $0-98.0 \%$ and $76.3 \%$, respectively. In comparison, $100 \mathrm{mg}$ twice daily for 3 days (total $600 \mathrm{mg}$ ), the recommended dose by WHO [45], showed fairly higher efficacies of $80.0 \%$ CR and 41.0$100 \%$ ERR according to reports from 27 trials [10]. However, the efficacy of mebendazole was variable depending on the species of hookworms. For example, using the recommended dose of mebendazole, the CR of A. duodenale was $71.4 \%$ and the ERR was $97.3 \%$ as reported by Seo et al. [54], whereas the CR of N. americanus was lower $52.0 \%$ and the ERR was $91.2 \%$ as reported by Sinniah et al. [55].

Tribendimidine (400 mg single dose) may be an alternative drug to treat hookworm infections having CR of 83.4\% (68.792.0\%) and ERR of 91.6\% (82.6-96.8\%) [42].

\section{Trichuriasis}

The efficacy of albendazole for Trichuris trichiura was first studied in the early 1980 s $[2,51,52,56]$. Some of these studies reported quite satisfactory results using $200 \mathrm{mg}$ twice (400 mg in total) with CR of $80.0-88.0 \%$ and ERR of $98.0-99.0 \%$ [51,56]. However, some others using $400 \mathrm{mg}$ in a single dose or $200 \mathrm{mg}$ twice reported lower efficacies, 50.0-61.5\% in CR and $76.5-95.0 \%$ in ERR $[2,13,52]$. WHO [45] recommended $400 \mathrm{mg}$ single dose as the recommended dose for moderate $\mathrm{T}$. trichiura infection, but in heavy infections 3-day course (total 1,200 mg) has been recommended. Horton [53] summarized the effects of albendazole ( $400 \mathrm{mg}$ single dose) for T. trichiura reported until March 1998 worldwide (58 studies) to be highly variable, from $4.9 \%$ to $100 \%$ (av. $47.7 \%$ ) in CR and $28.0 \%$ to $99.0 \%$ (av. $75.4 \%$ ) in ERR. However, the therapeutic efficacy of albendazole against trichuriasis seemed to be progressively lowered. A study in Lao PDR in 2012 reported only 33.3\% CR and 67.0\% ERR [44]. In 2 publications in 2017 [43] and 2019 [42], the CRs were reported as $30.7 \%$ and $32.1 \%$, and the ERRs were $49.9 \%$ and $64.3 \%$, respectively. Moser et al. $[42,43]$ put an emphasis on a temporal decrease of ERR which was $72.6 \%$ in 1995 and $43.4 \%$ in 2015 and considered this temporal decrease of albendazole efficacy against $T$. trichiura to be in part due to an emergence of drug resistance. Chai et al.
[46] tried to control A. lumbricoides and T. trichiura infections among schoolchildren in Myanmar by MDA using a $400 \mathrm{mg}$ single dose of albendazole but difficulties were experienced in short-term control of trichuriasis seemingly because of limited drug efficacy against $T$. trichiura.

Mebendazole was first tried to treat T. trichiura infection in the early 1970s [48]. A single dose of $300 \mathrm{mg}$ or $200 \mathrm{mg}$ showed $44.4 \%$ or $70.0 \%$ CR and $96.4 \%$ and $98.3 \%$ ERR, respectively, and $100 \mathrm{mg}$ b.i.d. for 2-4 days increased the efficacies, 75.090.0\% in CR and 99.3-99.6\% in ERR [48]. However, Seo et al. [54] obtained a poor efficacy of $100 \mathrm{mg}$ mebendazole twice daily for 3 days against $T$. trichiura infection only as $27.3 \%$ CR and $65.5 \%$ ERR. Kim [57] used 2 dosage regimens (total 600 $\mathrm{mg}$ ), $100 \mathrm{mg}$ b.i.d. for 3 days and $300 \mathrm{mg}$ daily for 2 days, and obtained different results, 36.1\% CR and 79.3\% ERR for the former and $71.0 \%$ CR and 85.4\% ERR for the latter regimen. Abadi [50] reported fairly good results using $500 \mathrm{mg}$ single dose of mebendazole, $77.6 \%$ CR and $92.8 \%$ ERR. WHO [45] set $100 \mathrm{mg}$ b.i.d. for 3 days as the recommended dose of mebendazole for treatment of T. trichiura infection with a 500 $\mathrm{mg}$ single dose as an alternative regimen. It is of note that Seo et al. [58] reported a satisfactory effect in long-term control of T. trichiura infection in Korea by repeated MDA using the recommended 3-day regimen of mebendazole, from $40.0 \%$ precontrol prevalence to $5.6 \%$ post-control prevalence a year later. Recently, however, the $500 \mathrm{mg}$ single dose regimen showed lower efficacies, 27.9\% CR and 66.0\% ERR in 2012 [44] (Table 1), $42.1 \%$ CR and $66.0 \%$ ERR in 2017 [43], and $44.4 \%$ CR and 80.7\% ERR in 2017 [42]. Moser et al. [42,43] reported a more remarkable (compared with albendazole) temporal decrease of ERR in T. trichiura which was $91.4 \%$ in 1995 that became $54.7 \%$ in 2015 . They considered this temporal decrease of the drug efficacy to be in part due to an emergence of drug resistance of worms.

Oxantel pamoate (20 mg/kg single dose) alone or in combination with albendazole (400 mg single dose) can be an alternative drug or drug regimen for trichuriasis [42].

\section{Strongyloidiasis}

Albendazole was evaluated to be partially effective for treatment of Strongyloides stercoralis infection, whereas mebendazole was never shown to be effective for strongyloidiasis [59]. In 1982, albendazole (400 mg daily for 3 days) was reported to have some effects against $S$. stercoralis infection, $48.0 \%$ in CR [51]. The ERR for this infection was not calculated because 
the diagnosis of strongyloidiasis is usually based on detection of larvae by a concentration method [53]. In addition, higher doses of albendazole, $400 \mathrm{mg}$ b.i.d. for 3 or 7 days, revealed 100\% CR [14] (Table 1). WHO [45] recommended the regimen of albendazole for strongyloidiasis as $400 \mathrm{mg}$ daily for $\geq 3$ days. Horton [53] reviewed the efficacy of albendazole (400 mg daily for 3 days) against $S$. stercoralis infection, and the average CR was $62.2 \%$ (16.7-100\% in range) calculated from 19 studies performed until March 1998. However, in immunocompromised patients with $S$. stercoralis hyperinfection syndrome, even 5 courses of albendazole ( $400 \mathrm{mg}$ daily for 3 days) failed to cure the disease [60].

An alternative drug, ivermectin ( $200 \mu \mathrm{g} / \mathrm{kg}$ daily for 2 days), resulted in more people cured than albendazole, and equally tolerated [59]. In northwestern Argentina, albendazole plus ivermectin was tried to control. Stercoralis and hookworm infections and was found to be effective for reduction of the prevalence as well as the morbidity due to these parasite infections [61].

\section{Enterobiasis}

Both albendazole and mebendazole have been shown to be highly effective against Enterobius vermicularis infection. The first clinical trial of albendazole was performed in the early 1980s [53]. Thereafter until March 1998, many clinical trials (at least 26 trials) were performed using $400 \mathrm{mg}$ single dose of albendazole (recommended dose by WHO [45]) [53]. In most trials, the CR at day 14-17 post-treatment ranged from 93.3 to $100 \%$ [53]. In South Korea, Rim et al. [13] reported 98.1\% CR when follow-up examinations were done on day 14 and 28 post-treatment (Table 1). Also, Chai et al. [62] obtained 100\% CR at day 14 post-treatment using $400 \mathrm{mg}$ single dose of albendazole. Reduced doses, $100 \mathrm{mg}$ or $200 \mathrm{mg}$ in a single dose, of albendazole were as effective as the recommended dose [63]. For chemotherapeutic control of enterobiasis using MDA with albendazole in a family or a group of people, treatment should be repeated at least 2 or more times every 2-3 weeks $[8,45]$.

Mebendazole was first used in clinical trial for enterobiasis in 1971 [4]. This drug, in a standard dose of $100 \mathrm{mg}$ single dose [45], was reported to have been satisfactory for treatment of $E$. vermicularis infection in adults ( $88 \% \mathrm{CR}$ ) as well as children (91\%) [4]. Higher doses, $100 \mathrm{mg}$ b.i.d. for 3 days (total $600 \mathrm{mg}$ ) or $200 \mathrm{mg}$ or $400 \mathrm{mg}$ in a single dose, revealed similar therapeutic effects $[4,54,63]$. It is notable that the anthel- mintic efficacy of mebendazole against young/juvenile worms of E. vermicularis was higher than that of pyrvinium pamoate or pyrantel pamoate [64]. Thus, the rate and timing of egg positive conversion (due to limited drug efficacy) after MDA were low and delayed in a highly endemic group of children if mebendazole (100 mg single dose) was used but the rate and timing of egg positive conversion were high and rapid if pyrvinium pamoate or pyrantel pamoate was used [64]. For chemotherapeutic control of enterobiasis using mebendazole 100 $\mathrm{mg}$ single dose in a group of children, MDA should be repeated at least 2-3 times at 3-week intervals [65].

\section{Taeniases}

Albendazole was used for treatment of taeniases due to Taenia spp. (T. saginata and T. solium) for the first time by Rim et al. $[13,21]$. Whereas single dose regimens ( $400 \mathrm{mg}$ or $800 \mathrm{mg}$ ) were almost ineffective, the dosage showing therapeutic efficacy was $400 \mathrm{mg}$ b.i.d. or t.i.d. for 2-3 days (total 1,600-3,600 $\mathrm{mg})[13,21]$. Using this dosage regimen, slightly better efficacy was obtained against T. saginata (90.0-95.0\% CR) than against T. solium (70.0-92.9\% CR) infection [13,21] (Table 1). Thereafter, based on 8 trials performed until March 1998 using a reduced dosage regimen of $400 \mathrm{mg}$ daily for 3 days (total 1,200 $\mathrm{mg}$ ), CR of $75.7-100 \%$ was obtained [53]. In other trials, a single dose of $400 \mathrm{mg}$ for adults and $200 \mathrm{mg}$ for children showed low efficacy with 50.0-58.8\% CR, whereas triple doses repeated for 3 days brought about $100 \%$ CR $[23,66]$.

Mebendazole was also proved to be effective against Taenia spp. infection if used in multiple doses, for example, $100 \mathrm{mg}$ b.i.d. for 3 days [67], $300 \mathrm{mg}$ b.i.d. for 3 days [68], or $500 \mathrm{mg}$ daily for 3 days [23]. In particular, the CR of multiple doses, $500 \mathrm{mg}$ daily for 3 days, was $100 \%$, whereas that of $500 \mathrm{mg}$ single dose was only $50.0 \%$ [23].

Praziquantel (5-10 mg/kg single dose) is the drug of choice for human intestinal taeniases [69]. Niclosamide is an alternative drug.

\section{Hymenolepiasis}

The therapeutic efficacy of albendazole against human $\mathrm{Hy}$ menolepis nana infection has been variable [53]. Whereas Rossignol and Maisonneuve [70] reported the CR of only $29.4 \%$ using $400 \mathrm{mg}$ albendazole daily for 3 days, Rim et al. [13] reported the CR of $66.7 \%$ using $800 \mathrm{mg}$ daily for 2 days (Table 1). Horton [53] reviewed the CR of human $H$. nana infection using $400 \mathrm{mg}$ albendazole daily for 3 days in 13 trials from 
1981 until March 1998 to be in the range between 28.5\% and 100\% (av. 69.5\%). However, shorter courses, particularly 400 $\mathrm{mg}$ single dose, do not appear to produce a significant cure of the disease [53].

Human hymenolepiasis ( $H$. nana) has been shown to be relatively insensitive to a standard 3-day course regimen of mebendazole (100 mg b.i.d. for 3 days) with CR ranging from only $18 \%$ to $40 \%$ [71].

Praziquantel (15-25 mg/kg single dose) is the drug of choice for hymenolepiasis [69]. However, to avoid recurrence of hymenolepiasis, a repeated treatment after 14 days is recommended [69].

\section{TISSUE HELMINTHIASES}

\section{Visceral, ocular, and neural larva migrans}

Human toxocariasis or visceral, ocular, and neural larva migrans are most commonly caused by the larvae of Toxocara canis (dog ascarid) and less commonly Toxocara cati (cat ascarid) [72]. Albendazole was experimentally shown to be effective against the larval stage of T. canis in mice [73]. Subsequently, albendazole began to be used for treatment of human toxocariasis (visceral or ocular larva migrans) with the dosage regimen of $5 \mathrm{mg} / \mathrm{kg}$ b.i.d. for 5 days; however, only 6 (31.6\%) of 19 patients were clinically cured, and 11 (57.9\%) showed excellent or good drug tolerability [74]. In ocular toxocariasis (5 patients involving 7 eyes), treatment with a higher dose for longer days, $800 \mathrm{mg}$ b.i.d. for 14 days, produced good results with no relapse and no side effects [75]. In the United States, the regimen of albendazole to treat visceral larva migrans was set at $800 \mathrm{mg}$ daily for 5 days [76] (Table 2). However, for neural toxocariasis albendazole should be given $800 \mathrm{mg}$ daily (15 $\mathrm{mg} / \mathrm{kg}$ for children) for longer duration, 21-28 days [77-79]. Moreover, in Japan, even an additional second course of 28day treatment, following the first 28-day course treatment with albendazole (10-15 mg/kg daily) and 14 days of drug free, was needed to obtain cure of 192 (78.0\%) of 246 patients with larva migrans syndrome [80].

Mebendazole was tried to treat visceral larva migrans. At least $20-25 \mathrm{mg} / \mathrm{kg}$ daily for 21 days was needed to treat human toxocariasis [81]. However, The Medical Letter [76] recommended 100-200 mg b.i.d. for 5 days for human visceral larva migrans due to Toxocara spp.

\section{Cutaneous larva migrans}

Cutaneous larva migrans is most commonly caused by the larvae of Ancylostoma brasiliense (dog and cat hookworm) and less commonly Ancylostoma caninum (dog hookworm). Albendazole at the dose of $400 \mathrm{mg}$ daily for 5 days showed fairly good results in 15 of 18 patients with cutaneous larva migrans [82]. However, longer period use of oral albendazole (400 mg daily), for 10-21 days, was reported in 5 cases of cutaneous larva migrans over buttocks and perianal regions in children [83]. Topical application of $4 \%$ albendazole cream (office-made with Vaseline) on the affected skin lesions of 3 cutaneous larva migrans cases also showed effects in 2 adults and 1 child patient [84].

Mebendazole has seldom been tried to treat cutaneous larva migrans because it seems less efficacious than albendazole. A 47-year-old man having erythematous, serpiginous burrows on both feet and right thigh and buttock received 2 courses of mebendazole therapy ( 3 days each, drug dosage not described), and 70\% resolution of skin lesions was obtained [85]. However, he developed pulmonary infiltrates with Löffler syndrome (shortness of breath, wheezing, and chest discomfort), and was prescribed with albendazole and intravenous hydrocortisone for 5 days and then completely cured [85].

\section{Anisakiasis (anisakidosis)}

Human anisakiasis (or anisakidosis) is mainly caused by Anisakis simplex, Anisakis pegreffii, Anisakis physeteris, and Pseudoterranova decipiens, and the treatment of choice is gastroendoscopic removal of the larvae or surgical excision of the affected lesion $[86,87]$. However, albendazole or mebendazole may be prescribed as a supplementary therapy $[9,88-90]$ or in cases where the larvae have penetrated the thickness of the stomach or intestinal wall [91]. The use of albendazole (400 mg b.i.d for 21 days) in human anisakiasis was first reported by Moore et al. [88] which was followed by several workers [89]. However, the use of albendazole alone is controversial regarding its efficacy for treatment of this disease [91].

Mebendazole was rarely tried for treatment of human anisakiasis. Maggi et al. [92] used mebendazole $100 \mathrm{mg}$ b.i.d for 3 days in 2 anisakiasis patients, i.e., mebendazole alone in 1 case and supplementary to surgery in another case. The results were satisfactory in both cases. Moschella et al. [93] used the same dosage of mebendazole for post-operative treatment of a patient with intestinal anisakiasis. Of considerable interest to note is that mebendazole was recently highlighted to be a 
Table 2. Albendazole and mebendazole for treatment of tissue-invading nematode infections

\begin{tabular}{|c|c|c|c|c|c|}
\hline Drug & Disease \& parasite & Regimen & Efficacy & Remark & References \\
\hline \multirow[t]{14}{*}{ Albendazole } & \multirow{3}{*}{$\begin{array}{l}\text { Visceral larva migrans } \\
\text { (Toxocara canis) }\end{array}$} & $800 \mathrm{mg} /$ day $\times 5$ days & Fairly effective & In USA & [76] \\
\hline & & $800 \mathrm{mg} /$ day $\times 21-28$ days & Fairly effective & Neural toxocariasis & [77-79] \\
\hline & & $800 \mathrm{mg} /$ day $\times 14$ days & Effective & Ocular toxocariasis & [75] \\
\hline & \multirow{2}{*}{$\begin{array}{l}\text { Cutaneous larva migrans } \\
\text { (Ancylostoma spp.) }\end{array}$} & $400 \mathrm{mg} /$ day $\times 5$ days & Satisfactory & 15 of 18 patients & [82] \\
\hline & & $400 \mathrm{mg} /$ day $\times 10-21$ days & Satisfactory & Buttock, perianal & [83] \\
\hline & Anisakiasis & 400 mg b.i.d. $\times 21$ days & Satisfactory & $\begin{array}{l}\text { Supplementary to endoscopic } \\
\text { removal of larvae or surgery }\end{array}$ & [88] \\
\hline & Trichinosis & $800 \mathrm{mg} /$ day $\times 8-15$ days & Effective & $\begin{array}{l}\text { Combined with methimazole to } \\
\text { increase drug absorption }\end{array}$ & {$[76,98-101]$} \\
\hline & Hepatic capillariasis & $400 \mathrm{mg} /$ day $\times 21-100$ days & Satisfactory & Combined with steroids & [110] \\
\hline & Intestinal capillariasis & $400-800 \mathrm{mg} /$ day $\times 10-30$ days & Satisfactory & As effective as mebendazole & {$[112-114,118]$} \\
\hline & Angiostrongyliasis & $200-1,000 \mathrm{mg} /$ day $\times 7-14$ days & Effective & $\begin{array}{l}\text { Combined with } \\
\text { dexamethasone }\end{array}$ & [124-126] \\
\hline & Gnathostomiasis & $400-1,200 \mathrm{mg} /$ day $\times 21$ days & Satisfactory & CR; 93.9-94.1\% & {$[133,138]$} \\
\hline & Gongylonemiasis & $400 \mathrm{mg} /$ day $\times 30$ days & Effective & Esophageal infection & [148] \\
\hline & Thelaziasis & $400 \mathrm{mg} /$ day $\times 3$ days & $\begin{array}{l}\text { Remains to be } \\
\text { determined }\end{array}$ & $\begin{array}{l}\text { Supplementary to surgical } \\
\text { extraction of worms }\end{array}$ & [152] \\
\hline & Dracunculiasis & $\begin{array}{c}\text { Poor drug candidate for this } \\
\text { disease }\end{array}$ & - & - & - \\
\hline \multirow[t]{13}{*}{ Mebendazole } & \multirow{2}{*}{$\begin{array}{l}\text { Visceral larva migrans } \\
\text { (Toxocara canis) }\end{array}$} & $100-200 \mathrm{mg}$ b.i.d. $\times 5$ days & Effective & - & [76] \\
\hline & & $20-25 \mathrm{mg} / \mathrm{kg} /$ day $\times 21$ days & Effective & - & [81] \\
\hline & $\begin{array}{l}\text { Cutaneous larva migrans } \\
\text { (Ancylostoma spp.) }\end{array}$ & Clinical trial seldom done & - & $\begin{array}{l}\text { Albendazole better than } \\
\text { mebendazole }\end{array}$ & [85] \\
\hline & Anisakiasis & $100 \mathrm{mg}$ b.i.d. $\times 3$ days & Fairly effective & Supplementary to surgery & [92] \\
\hline & \multirow[t]{2}{*}{ Trichinosis } & $5 \mathrm{mg} / \mathrm{kg} /$ day $\times 10-15$ days & Effective & - & [99] \\
\hline & & $\begin{array}{l}200-400 \mathrm{mg} \text { t.i.d. } \times 3 \text { days, and } \\
\text { then } 400-500 \mathrm{mg} \text { t.i.d. } \times 10 \text { days }\end{array}$ & Effective & - & {$[76,100]$} \\
\hline & Hepatic capillariasis & Clinical trial needed & - & - & - \\
\hline & Intestinal capillariasis & $200-400 \mathrm{mg} /$ day $\times 20-30$ days & Satisfactory & As effective as albendazole & {$[115,120]$} \\
\hline & Angiostrongyliasis & $10 \mathrm{mg} / \mathrm{kg} /$ day $\times 14$ days & Effective & Steroid needs to be combined & [129] \\
\hline & Gnathostomiasis & $200 \mathrm{mg} /$ day $\times 21$ days & Effective & After surgery & [142] \\
\hline & Gongylonemiasis & Clinical trial needed & - & - & - \\
\hline & Thelaziasis & Clinical trial needed & - & - & - \\
\hline & Dracunculiasis & $\begin{array}{c}\text { Poor drug candidate for this } \\
\text { disease }\end{array}$ & - & - & - \\
\hline
\end{tabular}

more effective drug than albendazole and flubendazole in reducing lesion occurrence in experimentally infected rats [94].

\section{Trichinosis}

The efficacy of albendazole against Trichinella spiralis infection was first confirmed by McCracken [95] in experimental mice; treatment with $50 \mathrm{mg} / \mathrm{kg}$ for 5 consecutive days reduced the number of muscle larvae by $67 \%$ compared to controls. However, this efficacy of albendazole was worse than that of mebendazole (at the same dosage regimen) which revealed
$96 \%$ reduction rate of muscle larvae [95]. The therapeutic usefulness of albendazole for human patients in combination with steroids was investigated during an outbreak of trichinosis in France by Fourestie et al. [96]. The regimen of albendazole was $400 \mathrm{mg}$ daily for 3 days and then $800 \mathrm{mg}$ daily for 15 days. Another study in France reported use of albendazole at the dose of $13 \pm 2.6 \mathrm{mg} / \mathrm{kg}$ daily for 8 days with satisfactory therapeutic effects with no side effects [97]. Thereafter, the recommended regimen of albendazole for treatment of human trichinosis has been settled at $800 \mathrm{mg}(15 \mathrm{mg} / \mathrm{kg})$ daily for 
8-14 days [76,98] or 10-15 days $[99,100]$ Albendazole is poorly absorbed through the intestinal tract especially in humans [3]. Thus, in order to increase the bioavailability of the drug in the plasma and enhance the therapeutic efficacy, trials have been made by co-administration with methimazole [101], using solid dispersion and cyclodextrin complexation techniques [102] or chitosan coated nanostructured lipid carriers [103].

Mebendazole at the dose of $50 \mathrm{mg} / \mathrm{kg}$ daily for 8-14 days was shown to be effective against migrating larvae of T. spiralis in experimental mice [104]. The clinical trial of mebendazole (1,000 mg daily for 14 days) for human trichinosis was reported in 1977, and no side effects were observed [105]. Use of prolonged ( 2 courses) and a higher dose of mebendazole was reported in a human patient unresponsive to steroid therapy [106]. In experimental mice, mebendazole showed better effects to kill muscle larvae than albendazole [95]. However, the effect of mebendazole was limited in human trichinosis because it was effective only on newborn larvae in lymph and blood vessels but not on encapsulating larvae in muscle cells [107]. The dosage of mebendazole for trichinosis has now been settled at $5 \mathrm{mg} / \mathrm{kg}$ daily for 10-15 days [99] or $200-400$ mg t.i.d. for 3 days followed by $400-500$ mg t.i.d. for 10 days $[76,98,100]$.

\section{Hepatic capillariasis}

Albendazole and mebendazole were tried for treatment of hepatic capillariasis (frequently fatal especially in children), due to Capillaria hepatica, by observing reduction of egg deposition in the liver of experimental mice [108]. Both drugs were found to be effective, although mebendazole appeared to be more useful as the effects could be obtained using dosage regimens within the range recommended for humans; 10 times higher dosage was required for albendazole to obtain the same results [108]. However, clinical trial has been reported only in albendazole but not in mebendazole.

The first clinical use of albendazole $(10-20 \mathrm{mg} / \mathrm{kg}$ daily for 20 days) was reported in a child case with only a limited success, which was followed by thiabendazole $(25 \mathrm{mg} / \mathrm{kg}$ daily for 27 days) and prednisolone (10 mg daily) therapy with final survival of the patient [109]. Albendazole was again used in 2 patients; $400 \mathrm{mg}$ daily for 21 days and 100 days (in combination with steroids) each, and the results were both satisfactory [110]. Thus, the drug of choice for hepatic capillariasis is currently thiabendazole or albendazole for 21 days [111]. The clinical use of mebendazole for human hepatic capillariasis re- mains to be tried.

\section{Intestinal capillariasis}

Human intestinal capillariasis due to Capillaria philippinensis has been treated with albendazole or mebendazole. In 1987, Cross and Basaca-Sevilla [112] used albendazole (400 mg daily for 10 days) in 16 intestinal capillariasis patients, and 15 were completely cured. One treatment failure case was retreated with mebendazole $400 \mathrm{mg}$ daily for 20 days with success; however, they recommended albendazole as the drug of choice [112]. Thereafter, many workers used albendazole for treatment of this disease, including Lee et al. [113], Hong et al. [114], Bair et al. [115], Soukhathamvong et al. [116], Rana et al. [117], and Sadaow et al. [118]. The dosage regimen of albendazole has been 400-800 mg daily for 10-30 days.

The use of mebendazole for human intestinal capillariasis seems to be first tried by Alcantara et al. [119] in 1985. The patient experienced an obstinate course of the disease, including 16 episodes in 12 years, and was treated with thiabendazole, mebendazole, and flubendazole. The final treatment with mebendazole (200 mg daily) for a total of 8.5 months resulted in clinical and parasitological cures without further relapses [119]. Thereafter, mebendazole (200-400 mg daily for 20-30 days) was recommended as the drug of choice for intestinal capillariasis [115,120-122]. However, after albendazole was proved to be also effective, both drugs have been recommended as the drug of choice for human intestinal capillariasis by The Medical Letter [76].

\section{Angiostrongyliasis}

Use of anthelmintics in eosinophilic meningoencephalitis due to Angiostrongylus cantonensis infection (cerebral angiostrongyliasis in humans) has been controversial. Most patients have a self-limited course and recover completely, and analgesics, corticosteroids, and careful removal of cerebrospinal fluid at frequent intervals can relieve symptoms from increased intracranial pressure [76]. However, Hwang and Chen [123] suggested the usefulness of albendazole for treatment of $A$. cantonensis infection in children. Thereafter, a combination therapy of albendazole (200-1,000 mg daily for 7-14 days) with dexamethasone (or prednisolone) effectively treated eosinophilic meningoencephalitis patients [124-126]. Federspiel et al. [127] reviewed the literature of $22 \mathrm{~A}$. cantonensis cases reported since 1988 , and found that 12 of the 22 cases were treated with albendazole in combination with corticosteroids. Some studies 
$[125,126]$ agreed that albendazole was useful for reducing the clinical symptoms, including headache. However, others do not recognize the superiority of using albendazole in combination with corticosteroids over corticosteroid treatment alone [127].

Mebendazole, combined with glucocorticosteroids, was reported to be effective in treatment of $A$. cantonensis infection; it appeared to shorten the course of infection though not the number of relapses [128]. Chotmongkol et al. [129] used mebendazole (10 $\mathrm{mg} / \mathrm{kg}$ daily for 14 days) in combination with prednisolone in 41 patients, and headache completely disappeared in 37 (90.2\%) patients within 14 days of treatment. However, Leone et al. [130] could not continue mebendazole treatment in a patient because of accentuation of the symptoms after the first dose of mebendazole; the patient was switched to steroid therapy. The usefulness of mebendazole for eosinophilic meningoencephalitis remains to be further defined.

In abdominal angiostrongyliasis due to infection with Angiostrongylus costaricensis, anthelmintics such as albendazole and mebendazole have not proven to be efficient, since the worms can cause lesions after their death inside the blood vessels [131].

\section{Gnathostomiasis}

Five species of Gnathostoma, including G. spinigerum, G. hispidum, G. doloresi, G. nipponicum, and G. binucleatum, have been reported to infect humans [132]. The first use of albendazole for treatment of human gnathostomiasis was reported in 1987 by Chitchang S. in a local journal (Thai) [133]. Subsequently, its usefulness (400-800 mg daily for 21 days) was confirmed with 93.9-94.1\% CR in 100 gnathostomiasis patients in Thailand [133]. Similar results were reported either using albendazole alone (the same regimen) or ivermectin alone $(0.2 \mathrm{mg} / \mathrm{kg}$ single or double doses) [134-137]. Chai et al. [138] used albendazole (1,200 mg daily for 21 days) in combination with ivermectin $(0.2 \mathrm{mg} / \mathrm{kg}$ single doe $)$ in $38 \mathrm{Ko}$ rean patients who immigrated to Myanmar with satisfactory results. However, superiority of albendazole alone or ivermectin alone for treatment of human gnathostomiasis has been controversial $[139,140]$. However, albendazole stimulates the outward migration of the gnathostome larva, thus making it more accessible and possibly amenable to excision [141].

Mebendazole has seldom been used for treatment of human gnathostomiasis. However, in a recent report from Mada- gascar, a G. spinigerum 3rd-stage larva was surgically extracted from an eye of a woman, and then mebendazole (200 mg daily for 21 days) was prescribed to treat probable further infection by Gnathostoma parasites and also to cure a wide spectrum of intestinal nematode infections [142].

\section{Gongylonemiasis}

Human gongylonemiasis, due to Gongylonema pulchrum, occurs on the lips, gums, tongue, and palate eliciting the sensation of a moving worm (s) in the buccal cavity [143]. Removal of the parasite may be curative; however, because of possible additional worms, anthelmintic drugs, including albendazole (400 mg daily for 3 days), have been prescribed [143-147]. However, in a patient having esophageal symptoms, this albendazole regimen failed to prevent recurrence, and a prolonged administration of albendazole ( $400 \mathrm{mg}$ daily for 30 days) was needed to obtain a complete cure [148].

In experimental rabbits, mebendazole $(70 \mathrm{mg} / \mathrm{kg}$ daily for 3 days) showed $22.8 \%$ reduction of worm burdens of $G$. pulchrum; however, levamisole ( $8 \mathrm{mg} / \mathrm{kg}$ single) revealed a higher reduction of $63.2 \%$ [149]. Clinical trials for mebendazole in human patients have been unavailable.

\section{Thelaziasis}

Human thelaziasis is mostly due to infection with Thelazia callipaeda and less frequently by Thelazia californiensis [150]. Mechanical removal of worms directly from the eyes of humans or animals is the first treatment of choice [150]. Nonetheless, this does not guarantee complete extraction of all parasites from the eyes; therefore, anti-parasitic medication is sometimes necessary [150]. Moxidectin and milbemycin oxime are the drugs of choice for thelaziasis; but mebendazole ( $20 \mathrm{mg} / \mathrm{kg}$ daily for 3 days) was also shown to be effective for cure of the infection in dogs [151]. In a human patient complaining of foreign body sensation in the right eye, $3 \mathrm{~T}$. callipaeda worms were retrieved, and albendazole (400 mg daily for 3 days) was prescribed for a supplementary purpose; this treatment was repeated 1 more time 2 weeks later [152]. However, the efficacy of albendazole and mebendazole in treating hidden $T$. callipaeda infection in the eyes remains to be further clarified.

\section{Dracunculiasis}

The treatment of dracunculiasis (due to Dracunculus medinensis) is largely dependent upon mechanical removal of 
worms (winding the emerging worm around a stick) from the subcutaneous tissue [153]. Medical treatment is usually not necessary, and drugs attacking the worm inside the host body may cause anaphylactic reaction due to the death of larvae [153]. However, dracunculiasis typically occurs in remote areas without easy access to medical attention, and anthelmintic drugs may be beneficial for such cases and also in mass, community-based control trials [154]. Nevertheless, albendazole, thiabendazole, metronidazole, ivermectin, and DEC showed no significant effects in managing this disease in animals, thus were poor candidates for clinical trials $[153,154]$.

\section{Cerebral and subcutaneous cysticercosis}

Albendazole began to be used for treatment of human neurocysticercosis caused by the metacestode of Taenia solium in 1987 by Escobedo et al. [155]. They observed that albendazole $(15 \mathrm{mg} / \mathrm{kg}$ daily for 30 days) was highly effective for treatment of patients with brain parenchymal cysticercosis; it was also effective in patients who had shown poor therapeutic response to praziquantel [155]. Sotelo et al. [156] recommended starting a course of albendazole ( $15 \mathrm{mg} / \mathrm{kg}$ daily for 30 days) therapy, and 3 months later, if parenchymal cysts are still detected, a course of praziquantel should be tried. Even a shorter course of treatment with albendazole ( $15 \mathrm{mg} / \mathrm{kg}$ daily for 3 days) was as effective as the 30-day course treatment [157]. Currently, the recommended regimen of albendazole for treatment of neurocysticercosis is $15 \mathrm{mg} / \mathrm{kg}$ daily for 8 days (7-15 days) in combination with steroids if necessary $[22,158,159]$ (Table 3 ). Albendazole was also found to be effective for subarachnoid and ventricular cysticercosis [160]. The antiparasitic activity of albendazole is closely related to bioavailability of its active compound, albendazole sulfoxide; in this form, the drug passes through the blood-brain barrier and reaches the central nervous system where it exerts its therapeutic effects [161].

Albendazole (15 mg/kg daily for 30 days) was highly effective against dermal and cutaneous cysticercosis; most subcutaneous nodules disappeared or were markedly reduced in size [162]. Almost the same dose of albendazole $(15 \mathrm{mg} / \mathrm{kg}$ daily for 28 days), in combination with steroids tapered over a period of 28 days, brought about complete recovery of ptosis due to extraocular muscle cysticercosis in the right eye [163]. However, it is of note that using corticosteroids in experimental cysticercosis by Taenia crassiceps negatively affected the efficacy of cysticidal activity of albendazole [164].

Mebendazole was assessed for use in treatment of cysticercosis in humans [165] and animals [166]. Some cures were documented but the results were equivocal and temporary inhibition of cyst growth or absence of a detectable effect were the more likely sequelae [165]. Thus, mebendazole alone is not recommended for human cysticercosis. However, meben-

Table 3. Albendazole and mebendazole for treatment of human cysticercosis and hydatidosis

\begin{tabular}{|c|c|c|c|c|c|}
\hline Drug & Disease \& parasite & Regimen & Efficacy & Remark & References \\
\hline \multirow[t]{4}{*}{ Albendazole } & $\begin{array}{l}\text { Neurocysticercosis } \\
\text { (metacestode of Taenia solium) }\end{array}$ & $15 \mathrm{mg} / \mathrm{kg} /$ day $\times 7-15$ days & Effective & $\begin{array}{l}\text { Parenchymal, subarachnoid, } \\
\text { and ventricular cysticerci } \\
\text { Combined with steroids }\end{array}$ & {$[22,158,159]$} \\
\hline & $\begin{array}{l}\text { Cutaneous cysticercosis } \\
\text { (metacestode of Taenia solium) }\end{array}$ & $15 \mathrm{mg} / \mathrm{kg} /$ day $\times 28$ days & Satisfactory & Combined with steroids & [163] \\
\hline & $\begin{array}{l}\text { Cystic echinococcosis } \\
\text { (hydatid of Echinococcus } \\
\text { granulosus) }\end{array}$ & $\begin{array}{l}400 \text { mg b.i.d. } \times 3-6 \text { months } \\
\text { with } 14 \text { days of break }\end{array}$ & Fairly good & Combined with PAIR ${ }^{a}$ & [174] \\
\hline & $\begin{array}{l}\text { Alveolar echinococcosis } \\
\text { (hydatid of Echinococcus } \\
\text { multilocularis) }\end{array}$ & $\begin{array}{l}400 \text { mg b.i.d. } \times 2-3 \text { years } \\
\text { with } 14 \text { days of break }\end{array}$ & Fairly good & $\begin{array}{l}\text { Minimum 2-3 years, but } \\
\text { probably lifelong }\end{array}$ & [174] \\
\hline \multirow[t]{4}{*}{ Mebendazole } & $\begin{array}{l}\text { Neurocysticercosis } \\
\text { (metacestode of Taenia solium) }\end{array}$ & $\begin{array}{l}\text { Mebendazole plus } \\
\text { praziquantel recommended }\end{array}$ & - & - & [164] \\
\hline & $\begin{array}{l}\text { Cutaneous cysticercosis } \\
\text { (metacestode of Taenia solium) }\end{array}$ & $\begin{array}{l}\text { Mebendazole plus } \\
\text { praziquantel recommended }\end{array}$ & & & [164] \\
\hline & $\begin{array}{l}\text { Cystic echinococcosis } \\
\text { (hydatid of Echinococcus } \\
\text { granulosus) }\end{array}$ & $\begin{array}{l}50-70 \mathrm{mg} / \mathrm{kg} / \mathrm{day} \times \\
6-24 \text { months }\end{array}$ & Fairly good & $\begin{array}{l}\text { Lower efficacy than } \\
\text { albendazole }\end{array}$ & {$[172,186]$} \\
\hline & $\begin{array}{l}\text { Alveolar echinococcosis } \\
\text { (hydatid of Echinococcus } \\
\text { multilocularis) }\end{array}$ & $45-48 \mathrm{mg} / \mathrm{kg} /$ day $\times 13$ years & Seemingly good & May be parasiticidal & [189] \\
\hline
\end{tabular}

aPAIR consists of puncture, aspiration, injection of scolicidal agent, and reaspiration. 
dazole in combination with praziquantel has been proposed to be a promising alternative for treatment of human or animal cysticercosis [167].

\section{Echinococcosis}

The primary choice of treatment for human cystic echinococcosis (= cystic hydatidosis) due to Echinococcus granulosus infection is surgery unless the cyst is multiple or inoperable [168]. Chemotherapy with anthelmintics, including albendazole, mebendazole, praziquantel, or nitazoxanide, is an alternative to surgery and for a pre-operative or post-operative treatment, as well as management of inoperable alveolar echinococcosis due to Echinococcus multilocularis by long-term chemotherapy $[168,169]$. Albendazole has been used since 1983 $[170,171]$. A great number of case studies were performed, and valuable results were obtained $[7,168,169,172-175]$. The dosage regimen of albendazole in the first 2 pilot studies was 10$14 \mathrm{mg} / \mathrm{kg}$ daily for 2-39 days [170] and $10 \mathrm{mg} / \mathrm{kg}$ daily for 5-8 days [171]. Currently the recommended dose is $400 \mathrm{mg}$ twice daily for 3-6 months with 14 days of break for cystic echinococcosis and $400 \mathrm{mg}$ twice daily for minimum 2-3 years for alveolar echinococcosis [174]. In the meantime, combined albendazole and praziquantel treatment was tried with good results $[176,177]$. However, because of toxicity issues the use of this drug combination needs further research [175]. On the other hand, percutaneous drainage method was introduced as an alternative therapy for patients with hepatic hydatid cysts who cannot undergo surgery [175,178-182]. The procedure consists of puncture (P), aspiration (A), injection of scolicidal agent (I), and reaspiration (R), so-called PAIR, and this method (PAIR) in combination with albendazole or mebendazole has been evaluated as a highly useful strategy for managing cystic hydatidosis [174,175,181,182]. Now, 4 treatment options for human cystic echinococcosis have been proposed; 1) surgery, 2) PAIR, 3) chemotherapy with albendazole, mebendazole or other anthelmintics, and 4) watch-and-wait for inactive or silent cysts [169].

Mebendazole was first shown to be effective in killing hydatid cysts (E. granulosus) in experimental mice [183]. Human cystic echinococcosis began to be treated with mebendazole (400-600 mg t.i.d. for 21-30 days), and regression of the cysts and clinical improvement were observed [184]. However, it often remained speculative whether the regressed cysts were completely destroyed [185]. Higher dose (50-70 mg/kg daily) of mebendazole with longer duration (6-24 months) was tried in human cystic echinococcosis, and its efficacy was compared with that of albendazole ( $10 \mathrm{mg} / \mathrm{kg}$ daily for 5.5 months) [172]. The treatment was partially or completely successful in 16 (57.1\%) of 28 patients treated with mebendazole and in $20(87.0 \%)$ of 23 patients treated with albendazole [172]. Other studies also supported superiority of albendazole over mebendazole for medical treatment of human cystic hydatid disease [169]. However, in children, mebendazole $(50 \mathrm{mg} / \mathrm{kg}$ daily for 9-18 months) was appropriate to use due to the lack of side effects, high therapeutic effects, and low risk of recurrence [186]. In addition, a combination of mebendazole (3,000 mg daily for 30 days) with praziquantel $(1,800 \mathrm{mg}$ daily for 15 days) with variable resting periods was suggested to be a good pharmacological alternative in the medical management of cystic echinococcosis [187]. The regimen of mebendazole in human cystic echinococcosis was studied by Vutova et al. [188]; it was concluded that the CR was increased both with dosage (from 30 to $70 \mathrm{mg} / \mathrm{kg}$ daily) and duration (from 6 to 24 months). PAIR plus pre- or post-operative mebendazole therapy brought about greater clinical and parasitological efficacy compared with surgery alone $[168,181,182]$. In alveolar echinococcosis, long-term mebendazole therapy (45-48 $\mathrm{mg} / \mathrm{kg}$ daily for 13 years) was suggested to have a good effect [189].

\section{LYMPHATIC FILARIASIS AND OTHER FILARIASIS}

\section{Lymphatic filariasis}

Lymphatic filariasis is caused by infection with filarial nematodes, especially, Wuchereria bancrofti, Brugia malayi, and less commonly Brugia timori, transmitted by vector mosquitoes [190]. The use of anthelmintic drugs is to kill microfilariae in the blood of patients (asymptomatic or symptomatic) which is beneficial for reduction of disease transmission to other people. The conventional chemotherapy for this purpose was 2-week course of diethylcarbamazine (DEC) ( $6 \mathrm{mg} / \mathrm{kg}$ daily); however, single doses of DEC $(4,6$ or $8 \mathrm{mg} / \mathrm{kg})$ were also found to be as effective as in long-term reduction of microfilaria levels up to 1 year after treatment [191]. This (DEC $6 \mathrm{mg}$ / $\mathrm{kg}$ in a single dose) had been for some time the mainstay of filariasis control programmes in the field [192]. In the meantime, 2-drug treatment with DEC and ivermectin both in single doses was shown to be more effective than treatment with either drug alone, yielding up to $99 \%$ clearance of microfilaremia up to 1 year after treatment $[192,193]$. However, signifi- 
cant concerns remained (severe side reactions, even fatal, occur due to DEC), and DEC made any multidrug regimen unsafe for community-wide use in Africa or elsewhere onchocerciasis or loiasis might coexist with bancroftian filariasis [192].

Jayakody et al. [194] was the first who formally conducted a study on the effectiveness of albendazole ( $800 \mathrm{mg}$ daily for 21 days) in comparison with DEC (6 mg/kg daily for 21 days) in $W$. bancrofti infection in humans. Although the microfilaricidal activities of these drugs were dramatic, the majority of the patients experienced severe adverse effects such as acute pain, fever, and inflammation of the scrotal sac and adjacent tissue, presumably induced by dying adult worms and microfilariae [194]. Therefore, this high dose and long-term use of albendazole was discouraged, and a single reduced dose (400 or 600 $\mathrm{mg})$, in combination with either ivermectin $(200-400 \mu \mathrm{g} / \mathrm{kg})$ or DEC (6 mg/ $/ \mathrm{kg})$, was tried; this new regimen proved to have both long-term effectiveness and safety in decreasing microfilaremia in W. bancrofti infection [195,196] (Table 4). However, albendazole should not be given as a single agent for lymphatic filariasis [197] except in areas co-endemic with Loa loa in Central Africa [198] or co-endemic with Onchocerca volvulus. The use of albendazole (400 $\mathrm{mg}$ in single dose) in combination with either ivermectin $(150-200 \mu \mathrm{g} / \mathrm{kg})$ or DEC $(6 \mathrm{mg} / \mathrm{kg})$ in single doses was found to be equally effective as DEC in combination with ivermectin against $W$. bancrofti infection in Africa or elsewhere in the world $[192,199]$. The combination of albendazole (400 $\mathrm{mg}$ in single dose) and DEC (6 mg/kg single dose) was found to be useful for treatment of also $B$. malayi infection in India [200] and B. timori infection in Indonesia [201] where there is no onchocerciasis or loiasis. Gyapong et al. [202] encouraged the use of albendazole in combination with ivermectin where onchocerciasis is co-endemic, and albendazole and DEC elsewhere. Nevertheless, it was suggested by Tisch et al. [203] that adding albendazole to DEC would provide less reduction in microfilarial prevalence and density than adding ivermectin to DEC. Addiss et al. [190], Critchley et al. [204], and Macfarlane et al. [205] were of opinion that not enough evidence had been gathered on the effectiveness of albendazole, alone or in combination with other drugs, for killing or interrupting transmission of filarial worms (adults and microfilariae) up to 12 months after treatment, and further well-controlled studies should be done. Although albendazole will not treat symptoms in people already affected by filariasis [205], it is of considerable importance to see that a significant proportion of children with $W$. bancrofti infection in India had their lymphatic pathology reversed when given the combination of albendazole and DEC annually or semiannually for 2 years [206]. In addition, a new therapeutic regimen, consisting of 3 drugs together (albendazole, DEC, and ivermectin), was tried for W. bancrofti filariasis, which was more effective in clearing microfilariae from the blood of the patients compared with a classical regimen, which consisted

Table 4. Albendazole and mebendazole for treatment of filarial nematode infections

\begin{tabular}{|c|c|c|c|c|c|}
\hline Drug & Disease \& parasite & Regimen & Efficacy & Remark & References \\
\hline \multirow[t]{6}{*}{ Albendazole } & $\begin{array}{l}\text { Lymphatic filariasis } \\
\text { (Wuchereria bancrofti) }\end{array}$ & $\begin{array}{c}400 \text { mg or } 600 \text { mg single } \\
\text { dose }\end{array}$ & Effective & $\begin{array}{c}\text { Combined with } \mathrm{DEC}^{\mathrm{a}} \text { or } \\
\text { ivermectin }\end{array}$ & {$[195,196]$} \\
\hline & Lymphatic filariasis (Brugia spp.) & 400 mg single dose & Effective & Combined with DEC & {$[200,201]$} \\
\hline & $\begin{array}{l}\text { Onchocerciasis } \\
\text { (Onchocerca volvulus) }\end{array}$ & 800 mg/day $\times 3$ days & Effective & Combined with oxycycline & {$[217]$} \\
\hline & Loiasis (Loa loa) & 800 mg/day $\times 28$ days & High recovery & Followed by ivermectin & {$[229]$} \\
\hline & $\begin{array}{l}\text { Mansonellosis } \\
\text { (Mansonella perstans) }\end{array}$ & $800 \mathrm{mg} /$ day $\times 10$ days & Favorable & $\begin{array}{l}\text { Doxycycline as an alternative } \\
\text { drug }\end{array}$ & {$[237,243,244]$} \\
\hline & Dirofilariasis (Dirofilaria immitis) & $800 \mathrm{mg} /$ day $\times 5$ days & Good & As conservative treatment & [250] \\
\hline \multirow[t]{6}{*}{ Mebendazole } & $\begin{array}{l}\text { Lymphatic filariasis } \\
\text { (Wuchereria bancrofti) }\end{array}$ & $30 \mathrm{mg} / \mathrm{kg} /$ day $\times 12$ days & Poor & Combined with DEC & {$[210]$} \\
\hline & Lymphatic filariasis (Brugia spp.) & Need trials & - & - & - \\
\hline & $\begin{array}{l}\text { Onchocerciasis } \\
\text { (Onchocerca volvulus) }\end{array}$ & Prolonged therapy needed & Poor & $\begin{array}{c}\text { Albendazole more potent than } \\
\text { mebendazole }\end{array}$ & {$[225]$} \\
\hline & Loiasis (Loa loa) & $\begin{array}{l}300-1,500 \mathrm{mg} / \text { day } \times \\
21 \text { days }\end{array}$ & Fairly good & $\begin{array}{l}\text { Albendazole better than } \\
\text { mebendazole }\end{array}$ & {$[235]$} \\
\hline & $\begin{array}{l}\text { Mansonellosis } \\
\text { (Mansonella perstans) }\end{array}$ & $\begin{array}{l}200-400 \mathrm{mg} / \text { day } \times \\
7-42 \text { days }\end{array}$ & Satisfactory & Combined with DEC & {$[237]$} \\
\hline & Dirofilariasis (Dirofilaria immitis) & Need trials & - & - & - \\
\hline
\end{tabular}

${ }^{a} \mathrm{DEC}$, diethylcarbamazine. 
of albendazole and DEC, in Côte d'Ivoire [207] and India [208].

Wolbachia endosymbiotic bacteria is closely associated with worm development, embryogenesis, fertility, and viability of filarial nematodes and synergistically involved in the pathogenesis and clinical features in filariasis patients [209]. The use of doxycycline (200 mg daily for 21 days) to kill Wolbachia endosymbionts in combination with albendazole and ivermectin single doses showed effectiveness in inducing a long-term reduction of microfilaria levels in patients with $W$. bancrofti infection [209].

Mebendazole has seldom been used for treatment of lymphatic filariasis. Sarma et al. [210] used mebendazole (30 mg/ kg daily for 12 days or weekly for 1 year) in combination with DEC but did not find any beneficial effect in most patients with clinical disease caused by W. bancrofti infection in India.

\section{Onchocerciasis}

The first drug of choice for onchocerciasis (Onchocerca volunlus infection) is ivermectin (150-200 $\mu \mathrm{g} / \mathrm{kg}$ single dose) [211]. Albendazole ( $800 \mathrm{mg}$ daily for 3 days) had been shown to be an alternative drug having a positive effect on prolonged suppression of skin microfilarial counts [212]. A prolonged course of albendazole treatment ( $400 \mathrm{mg}$ daily for 10 days) in $26 \mathrm{pa}-$ tients caused changes in microfilarial densities over a year period, presumably by interfering with embryogenesis, though not directly killing microfilariae [213]. However, a combination of shorter duration of albendazole ( $800 \mathrm{mg}$ daily for 3 days) with ivermectin (150 $\mu \mathrm{g} / \mathrm{kg}$ single dose) given 1 week apart did not produce any additional effect when compared with ivermectin alone [214]. Another trial using albendazole (400 $\mathrm{mg}$ single dose) with ivermectin (200 $\mu \mathrm{g} / \mathrm{kg}$ single dose) given concurrently also produced no advantage over ivermectin alone [211]. Repeated use (annually or semiannually) of albendazole (800 mg single dose) with ivermectin $(200 \mu \mathrm{g} / \mathrm{kg}$ single dose) for 2 years also showed no better results than ivermectin alone for sterilizing and killing adult worms or achieving sustained microfilarial clearance [215]. In the meantime, doxycycline (100 mg daily for 35-42 days or $200 \mathrm{mg}$ daily for 28 days) was shown to be effective in reducing the bacterial symbiont Wolbachia and finally in long-term (>24 months) sterilization of female O. volvulus worms and an absence of skin microfilariae [216]. A combination of doxycycline (200 mg daily for 21 days) with albendazole (800 mg daily for 3 days) produced better efficacy than either drug alone [217].
Fischer et al. [218] suggested a possibility that a new drug combination (ivermectin, DEC, and albendazole; IDA) which has been shown to be effective for control of lymphatic filariasis may also be effective for clearance and suppression of microfilariae of $O$. volvulus.

Mebendazole was found to be ineffective against $O$. volvulus in a Chimpanzee model; neither microfilariae nor adult worms on the skin were killed perhaps because the drug is poorly absorbed from the alimentary canal [219]. In human patients, mebendazole (200-300 mg daily for 6-30 days) alone or in combination with levamisole had no significant effects on the microfilariae or adult worms $[220,221]$, although a high dose of mebendazole was suggested to be useful and relatively safe for therapy of onchocerciasis [222]. However, neither mebendazole alone nor its combination with levamisole was strongly macrofilaricidal in the skin [223]. Further development of mebendazole for chemotherapy of onchocerciasis was abandoned because of the length of therapy and the brief duration (3 months) of the effects on adult worms [224]. Albendazole is much more potent than mebendazole, its significant activity is achieved with a single dose, and prolonged therapy like mebendazole is unnecessary [225].

\section{Loiasis}

The filaricidal activity of albendazole (400 mg daily for 21 days) in human loiasis (Loa loa) was first confirmed from a double-blind, placebo-controlled clinical trial in 1993 in Benin [226]. In addition, albendazole (400 mg daily for 21 days) was found to be useful for loiasis refractory to DEC treatment [227]. Albendazole is considered to be embryotoxic resulting in a slow decrease of microfilaremia [226]. Arrey-Agbor et al. [228] reported a case of spontaneous encephalopathy due to loiasis whose microfilaremia was dramatically reduced with 21-day course of albendazole therapy. Gobbi et al. [229] obtained a high rate of recovery among 16 imported loiasis cases in Italy using a 28-day course of albendazole ( $800 \mathrm{mg}$ daily) treatment followed by ivermectin $(200 \mu \mathrm{g} / \mathrm{kg}$ in single or multiple doses). However, a 21-day course of treatment is not suited for population-based chemotherapy [230]. A reduced course of treatment with albendazole (400 mg daily for 3 days) was tried in 99 infected people in Cameroon but the results were not so satisfactory [230]. A 3-day course regimen with a higher dose ( $800 \mathrm{mg}$ daily) given in 47 patients in Cameroon also revealed no significant change in the overall microfilarial loads [231]. 
The first trial of mebendazole ( $2 \mathrm{~g}$ daily for 21-28 days) for treatment of loiasis was done by Richard-Lenoble et al. [232] in 1985 which reported a slight decrease in microfilaremia, although the same mebendazole regimen ( $2 \mathrm{~g}$ daily for 21 days) revealed no significant decrease in microfilaremia [233]. Mebendazole did not show any difference in efficacy according to different dosage, from $300 \mathrm{mg}$ to 1,500 mg daily, if used for 21 days, and 16 (84.2\%) of 19 enrolled patients revealed complete or partial reduction of microfilaremia [234]. The microfilarial reduction was more pronounced in patients treated with albendazole (600 mg single dose) than those with mebendazole (100 mg b.i.d. for 1 day) [235]. The 21-day course of mebendazole treatment may constitute a preliminary treatment to progressively decrease the microfilarial density below the threshold which ivermectin or DEC can be safely administered [236].

\section{Mansonellosis}

Three species of Mansonella, including M. perstans, M. streptocerca, and M. ozzardi, are responsible for causing human mansonellosis [237]. Among them, M. perstans is the most important and most difficult species to treat [237] and relatively resistant to standard antifilarial agents, including DEC, ivermectin, albendazole, and mebendazole [238]. Albendazole (800 mg daily for 3-10 days) was first tried for $M$. perstans filariasis in 1992 but the results were not so satisfactory [239]. However, 2 long courses of albendazole ( $800 \mathrm{mg}$ daily for 45 days) with 14 days' rest were effective in a patient with M. perstans filariasis [240]. The same dose of albendazole given for 10 days produced favorable results in 47 patients with decreased microfilaremia until 90 days after treatment [241]. However, a single dose of albendazole (400 mg) and ivermectin (150-200 $\mu \mathrm{g} / \mathrm{kg}$ ) combined and each drug alone revealed low efficacies [242]. To treat the endosymbiotic Wolbachia bacteria, doxycycline began to be used as a promising alternative drug since the 2010s, alone or in combination with anthelmintics $[237,243,244]$.

Mebendazole (200 mg daily for 42 days) was first shown to markedly reduce the number of microfilariae of $M$. perstans, and a combined use of mebendazole (200-400 mg daily for 7 days) with levamisole cleared the blood microfilaremia within 7 days [220]. Nine patients with M. perstans infection were also successfully treated with mebendazole ( $200 \mathrm{mg}$ daily for 28-42 days) [245,246]. In another study, all of 16 cases infected with $M$. perstans revealed dramatically reduced parasitemia after mebendazole (300-1,500 mg daily for 21-45 days) treatment [234]. The efficacy of different anthelmintics against M. perstans filariasis was evaluated in 165 patients, and mebendazole (200 mg daily for 28 days) appeared to be more active than DEC (400 mg daily for 21 days) in eliminating the disease; a combined use of mebendazole (100-200 mg daily for 14-21 days) with DEC (400 mg daily for 21 days) produced better effects than mebendazole or DEC alone, with no increase of side effects [247]. Thus, mebendazole alone [238] or in combination with DEC is currently acknowledged as the most effective antiparasitic treatment to treat $M$. perstans infection [237].

\section{Dirofilariasis}

In human dirofilariasis (due either to Dirofilaria immitis or Dirofilaria repens), anthelmintic treatment is generally not recommended, and surgery is recommended if needed and feasible $[248,249]$. Antibacterial drugs, including doxycycline, may be useful to treat Wolbachia symbionts [248]. Surgery was not possible in 24 of 266 dirofilariasis patients in Russia because of active migration of parasites in tissues, and in such cases albendazole ( $800 \mathrm{mg}$ daily for 5 days) in combination with doxycycline (200 mg daily for 5 days) were prescribed for conservative treatment in 22 of the 24 patients with good results [250]. Surgery was done in 4 cases of pulmonary dirofilariasis, and post-operative medication was given with albendazole alone or in combination with DEC and doxycycline [251]. Mebendazole has seldom been tried for human dirofilariasis.

\section{TREMATODE INFECTIONS}

\section{Fascioliasis}

The treatment of choice for human fascioliasis (due to either Fasciola hepatica or Fasciola gigantica) currently is triclabendazole $[15,252,253]$. Praziquantel revealed no efficacy at all or only low-to-moderate CRs [252]. The efficacy of albendazole was first documented in the 1970s-1980s against fascioliasis in animals, including cattle and sheep $[1,254,255]$. Subsequently, albendazole began to be used for human fascioliasis; however, most of the treatments were unsuccessful [256-258]. Up to the present, according to available literature, only 2 human infections were successfully treated with albendazole $(1,200 \mathrm{mg}$ daily for 7 days) [17,259] (Table 5). Meanwhile, triclabendazole resistance of $F$. hepatica in livestock and patients was reported mainly from Western Europe [260], and use of albendazole was encouraged in such cases [261]. 
Table 5. Albendazole and mebendazole for treatment of trematode and protozoan infections

\begin{tabular}{|c|c|c|c|c|c|}
\hline Drug & Disease \& parasite & Regimen & Efficacy & Remark & References \\
\hline \multirow[t]{10}{*}{ Albendazole } & Fascioliasis & $\begin{array}{l}1,200 \mathrm{mg} / \text { day } \\
\times 7 \text { days }\end{array}$ & Successful & In triclabendazole resistance areas & {$[17,259]$} \\
\hline & Clonorchiasis & $\begin{array}{c}1,200-1,800 \mathrm{mg} / \text { day } \\
\times 3-5 \text { days }\end{array}$ & $\begin{array}{c}\text { CR } 84.6 \% \\
\text { ERR } 99.9-100 \%\end{array}$ & Praziquantel is the drug of choice & [13] \\
\hline & Opisthorchiasis & $\begin{array}{l}800 \mathrm{mg} / \text { day } \\
\times 3-7 \text { days }\end{array}$ & $\begin{array}{l}\text { CR } 60-96 \% \\
\text { ERR } 91-92 \%\end{array}$ & Praziquantel is the drug of choice & [14] \\
\hline & $\begin{array}{l}\text { Intestinal fluke infections } \\
\text { (metagonimiasis) }\end{array}$ & $\begin{array}{l}400 \mathrm{mg} / \text { day } \\
\times 2 \text { days }\end{array}$ & $\begin{array}{l}\text { CR } 61.1 \% \\
\text { ERR } 89.2 \%\end{array}$ & Praziquantel is the drug of choice & [13] \\
\hline & $\begin{array}{l}\text { Giardiasis } \\
\text { (Giardia duodenalis) }\end{array}$ & $\begin{array}{c}400 \mathrm{mg} / \text { day } \\
\times 5 \text { days (adults) } \\
10 \mathrm{mg} / \mathrm{kg} / \text { day } \\
\times 5 \text { days (children) }\end{array}$ & CR $81.0-94.8 \%$ & In children & {$[272,273]$} \\
\hline & $\begin{array}{l}\text { Vaginal trichomoniasis } \\
\text { (Trichomonas vaginalis) }\end{array}$ & Clinical trials needed & - & In metronidazole-resistant cases & [283] \\
\hline & Cryptosporidiosis & Clinical trial needed & - & Effective in animal experiments & [288] \\
\hline & $\begin{array}{l}\text { Microsporidiosis } \\
\text { (Encephalitozoon cuniculi, } \\
\text { E. hellem, and E. intestinalis) }\end{array}$ & $\begin{array}{l}800 \mathrm{mg} / \text { day } \\
\times 21-30 \text { days }\end{array}$ & Effective & Second dose if needed & {$[291,294-296]$} \\
\hline & $\begin{array}{l}\text { Microsporidiosis } \\
\text { (Microsporidium) }\end{array}$ & $\begin{array}{c}15 \mathrm{mg} / \mathrm{kg} / \text { day } \\
\times 7 \text { days }\end{array}$ & Effective & In diarrheal patients & [298] \\
\hline & $\begin{array}{l}\text { Microsporidiosis } \\
\text { (Enterocytozoon bienuesi) }\end{array}$ & $\begin{array}{l}800 \mathrm{mg} / \text { day } \\
\times 28 \text { days }\end{array}$ & Ineffective & Use fumagillin or TNP-470 & {$[289,299-303]$} \\
\hline \multirow[t]{8}{*}{ Mebendazole } & Fascioliasis & $4 \mathrm{~g} /$ day $\times 21$ days & Successful & In triclabendazole resistance areas & [20] \\
\hline & Clonorchiasis & 100 mg single & Ineffective & Praziquantel is the drug of choice & [18] \\
\hline & Opisthorchiasis & $\begin{array}{l}30 \mathrm{mg} / \mathrm{kg} / \mathrm{day} \\
\times 21-28 \text { days }\end{array}$ & CR $96.3 \%$ & Praziquantel is the drug of choice & [19] \\
\hline & $\begin{array}{l}\text { Intestinal fluke infections } \\
\text { (echinostomiasis) }\end{array}$ & $\begin{array}{l}400 \mathrm{mg} / \text { day } \\
\times 20 \text { days }\end{array}$ & Successful & Concomitantly treat intestinal capillariasis & [265] \\
\hline & Giardiasis (Giardia sp.) & $\begin{array}{l}600 \mathrm{mg} / \text { day } \\
\times 3-5 \text { days }\end{array}$ & Satisfactory & Children & [279] \\
\hline & $\begin{array}{l}\text { Vaginal trichomoniasis } \\
\text { (Trichomonas vaginalis) }\end{array}$ & Clinical trials needed & - & In metronidazole-resistant cases & [286] \\
\hline & Cryptosporidiosis & $\begin{array}{l}\text { Low susceptibility to } \\
\text { mebendazole }\end{array}$ & - & - & - \\
\hline & Microsporidiosis & $\begin{array}{l}\text { Low susceptibility to } \\
\text { mebendazole }\end{array}$ & - & Due to poor absorption & [307] \\
\hline
\end{tabular}

Mebendazole was rarely tried for treatment of human fascioliasis [15]. In 1 patient, a very high dose of mebendazole (4 g daily for 21 days) could treat human fascioliasis successfully with prompt normalization of eosinophil counts, liver enzymes abnormalities, and specific serologic test, together with disappearance of liver necrosis [20].

\section{Clonorchiasis and opisthorchiasis}

The drug of choice for clonorchiasis (due to Clonorchis sinensis) and opisthorchiasis (due to Opisthorchis viverrini or Opisthorchis felineus) is praziquantel $[10,15,69]$. Albendazole and mebendazole have also been used for these liver fluke infections $[10,15]$. In C. sinensis infection, a single dose of albendazole (400 mg) was almost ineffective, but multiple doses (for example, $400 \mathrm{mg}$ t.i.d. for 3 days or $600 \mathrm{mg}$ t.i.d. for 5 days) showed $84.6 \%$ and $100 \%$ CR and $99.9 \%$ and $100 \%$ ERR, respectively [13]. Similar results were reported; $5 \mathrm{mg} / \mathrm{kg}$ or 10 $\mathrm{mg} / \mathrm{kg}$ b.i.d. for 7 days brought about $90 \%$ and $100 \%$ CR, respectively [262]. In O. viverrini infection, albendazole (400 mg b.i.d. for 3 or 7 days) revealed fairly high CR (60\% or $96 \%)$ and ERR ( $91 \%$ or $92 \%$ ) at day 14 post-treatment, respectively, when examined by Stoll's method [14]. Therefore, the regimen of albendazole for treatment of clonorchiasis and opisthorchiasis should be $800-1,200 \mathrm{mg}$ daily for 5-7 days, and it is not so feasible for MDA.

Mebendazole was tried for treatment of clonorchiasis and opisthorchiasis. A single dose of mebendazole (100 mg) was ineffective against $C$. sinensis infection [18]. Higher doses of mebendazole (30 mg/kg daily for 21-28 days) were found to be highly effective against $O$. viverrini infection with 96.3\% CR 
[263]. However, this long-term medication is not useful for mass chemotherapy.

\section{Intestinal fluke infections}

For treatment of human intestinal fluke infections, including heterophyidiasis, echinostomiasis, neodiplostomiasis, and gymnophalloidiasis, praziquantel ( $10 \mathrm{mg} / \mathrm{kg}$ single dose) is the drug of choice [69], and the efficacy is usually satisfactory. However, albendazole was also tried for treatment of heterophyid fluke infections, including metagonimiasis due to Metagonimus yokogawai [13]. Its therapeutic efficacy was not so satisfactory with a single dose of $400 \mathrm{mg}$ with $33.3 \%$ CR and $60.0 \%$ ERR; however, a 2-day regimen with daily dose of 400 mg revealed CR of $61.1 \%$ and ERR of $89.2 \%$, respectively [13]. Albendazole showed similar effects on other heterophyid fluke infections. For example, Haplorchis taichui and Haplorchis yokogawai adult specimens were collected from the diarrheal stool of patients after treatment with albendazole (400 mg daily for 1 or 3 days) [264]. Adult echinostomes, including Echinostoma ilocanum and Artyfechinostomum malayanum, were also recovered from the diarrheal stool of 3 patients treated with albendazole ( $800 \mathrm{mg}$ daily for 3 or 7 days) [14].

A long-term use of mebendazole (400 mg daily for 20 days) was also found to be effective for treatment of echinostome ( $E$. ilocanum) infections in humans and animals [265].

\section{PROTOZOAN INFECTIONS}

\section{Giardiasis}

In vitro growth of Giardia spp. (G. lamblia, G. duodenalis, or G. intestinalis) was found to be highly sensitive to albendazole and mebendazole which had 30- to 50-fold higher activity than metronidazole, quinacrine, or tinidazole $[266,267]$. It was also shown that albendazole is active against $G$. duodenalis in vivo of mice [268] and dogs [269]. Albendazole seemed to damage the cytoskeletal elements of the ventral disk (= sucking disk) of $G$. duodenalis leading to loss of its ability to adhere to the intestinal villi and obtain nutrients [270]. A preliminary study on clinical use of albendazole (200-500 mg daily for 3 days for adults and $100 \mathrm{mg}$ daily for 3 days for children) for giardiasis patients revealed promising results [271]. Moreover, in children infected with $G$. duodenalis, treatment with a single dose of albendazole (600-800 mg) revealed 62.1-74.6\% CR, whereas multiple doses of albendazole ( $400 \mathrm{mg}$ daily for 3 or 5 days) produced higher effects, 81.0-94.8\% CR [272] (Table
5). Currently, the recommended dosage of albendazole for giardiasis is $400 \mathrm{mg}$ daily for 5 days for adults or $10 \mathrm{mg} / \mathrm{kg}$ daily for 5 days for children [273]. Synergistic effects were obtained by a combined use of albendazole and metronidazole $[274,275]$ and albendazole and secnidazole in treatment of patients who failed conventional treatments [276]. However, using suboptimal doses of albendazole may account for an increase in the prevalence of giardiasis in some areas and development of drug resistance [277].

The therapeutic effect ( $40 \% \mathrm{CR}$ ) of mebendazole (200 mg daily for 3 days) against human G. lamblia infection was first reported by Hutchison et al. [278] in 1975. Later, a higher dose of mebendazole ( $600 \mathrm{mg}$ daily for 3 or 5 days) was used, and 38 of 40 patients ( 26 were below 12 years old) were cured (95\% in CR) [279]. Mebendazole (600 mg daily for 5 days) was not effective for treatment of giardiasis in adult patients [280]. The efficacy of mebendazole was reported in another study; 21 (91.3\%) of 23 patients given mebendazole (600 mg daily for 5 days) were cured, whereas 18 (85.7\%) of 21 patients given metronidazole ( $600 \mathrm{mg}$ daily for 5 days) became free from infection [281]. It seemed that a higher dose of mebendazole may be needed in adult patients [281].

\section{Vaginal trichomoniasis}

The ultrastructural changes of Trichomonas vaginalis trophozoites after treatment with albendazole were studied by Oxberry et al. [270] in 1994 in comparison with those that occurred in G. duodenalis trophozoites. In G. duodenalis trophozoites, albendazole seemed to damage the cytoskeletal elements of the ventral disk; however, in T. vaginalis trophozoites, such a ventral disk is lacking and the action of albendazole did not seem to be as great as that [270]. Another in vitro study revealed higher efficacy of mebendazole in killing T. vaginalis trophozoites than albendazole [282]. However, it is of note that albendazole and coenzyme $B_{12}$ have been suggested to be helpful for treatment of patients with highly metronidazole (or tinidazole)-resistant T. vaginalis infections [283].

Antimicrotubular drugs, including mebendazole, flubendazole, and thiabendazole, were tested in vitro on their effects on growth and viability of T. vaginalis in 1985 [284]. Mebendazole was shown to be active at a lower concentration than albendazole [282]. Mebendazole was also shown to be effective against metronidazole-resistant and metronidazole-sensitive $T$. vaginalis strains in vitro $[30,285]$. However, in clinical use, mebendazole failed to cure 2 T. vaginalis patients who did not 
respond to metronidazole treatment [286].

\section{Cryptosporidiosis}

Human cryptosporidiosis is mainly caused by Cryptosporidium parvum and Cryptosporidium hominis. The albendazole and mebendazole susceptibility appeared to be low in C. parvum, whereas it was high in Encephalitozoon spp. and G. duodenalis $[282,287]$. It was demonstrated that the number of $C$. parrum parasites in histologic sections of intestine from mice treated with albendazole was significantly lower than that in untreated control mice; however, albendazole was not efficacious in clearing C. parrum infection in mice [288].

\section{Microsporidiosis}

Human microsporidiosis is caused by variable species of more than 9 genera belonging to the phylum Microsporidia (resembling fungi); the most important genera include Encephalitozoon, Enterocytozoon, Nosema/Vittaforma, Pleistophora, Anncalia (syn. Brachiola), and Microsporidium [289]. The therapeutic efficacy of albendazole ( $800 \mathrm{mg}$ daily for 28 days) against human microsporidiosis due to Enterocytozoon bieneusi was first suggested by Blanshard et al. [290] in 1992. Nacey et al. [291] reported favorable results of albendazole $(800 \mathrm{mg}$ daily for 30 days) in a case of naso-ocular microsporidiosis due to Encephalitozoon cuniculi or Encephalitozoon hellem. The albendazole efficacy against human E. cuniculi infection was repeatedly confirmed $[292,293]$. The albendazole susceptibility of E. cuniculi and E. hellem was predicted by the presence of $2 \beta$-tubulins, Glu-198 and Phe-200 [282]. Notably, however, E. cuniculi genotype III showed albendazole resistance in experimental mice [27]. Intestinal infection with Encephalitozoon intestinalis (syn. Septata intestinalis) also responded well to albendazole (800 mg daily for 28 days) [294,295], although in some patients only transient effects were seen [26]. A shorter duration treatment of albendazole ( $800 \mathrm{mg}$ daily for 21 days) was also effective in treatment of $E$. intestinalis infections in patients with AIDS and delayed the occurrence of relapse, and a few relapsed cases could be cleared from infection using a second course of albendazole for 21 days [296]. Similar results were reported by Leder et al. [297]. Further shorter duration of albendazole treatment $(15 \mathrm{mg} / \mathrm{kg}$ daily for 7 days) was tried and found to be effective in treatment of Microsporidium diarrheal patients [298]. However, E. bieneusi infection was not successfully cured using albendazole ( $800 \mathrm{mg}$ daily for 28 days), with parasites not completely cleared in small-bowel bi- opsies of the patients [299-302]. The drug of choice for E. bieneusi infection is fumagillin or its analog TNP-470 [289,303, 304]; however, fumagillin may cause significant bone marrow toxicity [305]. A combination of albendazole and fumagillin could successfully treat a case of disseminated Anncaliia algerae microsporidial infection [306].

Mebendazole was tested for its efficacy on a microsporidian species, E. intesinalis, cultured in vitro using Vero cells; it was highly active in killing the spores of E. intestinalis [307]. However, mebendazole is poorly absorbed and thus it is unclear whether this drug would provide a suitable alternative to albendazole [307].

\section{TOXICITY OF DRUGS}

\section{Albendazole}

Very few adverse events have been reported by treatment with albendazole [53]. At the recommended doses used for intestinal helminths, all reported events were mild and selflimiting (epigastric pain, diarrhea, headache, nausea, abdominal pain, dizziness, vomiting, lethargy, constipation, leucopenia, pruritus, etc.), and none have been serious or life-threatening [53]. Most problems are associated with higher dose treatment for systemic infections where problems of drug-parasite interactions cause specific syndromes such as abnormal liver functions (for example, in echinococcosis), central nervous system symptoms (in neurocysticercosis), or hematologic side effects [53,308-312]. Fatalities are extremely rare, and have almost entirely been associated with severe underlying diseases or AIDS-related infections [53]. Importantly, however, a pilot study using albendazole ( $10 \mathrm{mg} / \mathrm{kg}$ daily for 28 days) for treatment of 7 colorectal or hepatocellular carcinoma patients reported fatality in 1 patient presumably due to albendazole toxicity, in particular, severe neutropenia [37]. Further, the maximum tolerated daily dose of albendazole was found to be 2,400 mg (for 14 days in a 21-day cycle) in 6 patients with advanced cancers, and myelosuppression, including neutropenia, leukopenia, lymphopenia, and thrombocytopenia, was the main dose limting toxicity in 2 of the 6 patients [313].

Notably, however, even a single dose treatment (for empirical or seasonal use) of albendazole (400 mg) could cause acute liver toxicity in adult patients [39,314-318] as well as in children [319-322]. Such liver toxicity may be recurrent each time after administration of albendazole [317,318,320,321]. In another rare instance, acute renal failure occurred after taking 
albendazole (800 mg daily for 2 days) to treat trichinosis [323]. Albendazole is known to be a teratogen and fetal toxicant in experimental animals at very high doses [3]. Albendazole is contraindicated during pregnancy in humans $[3,11]$.

\section{Mebendazole}

Mebendazole is a highly safe anthelmintic drug if used in recommended doses. One of the most important adverse effects is hepatotoxicity, although its incidence is very rare [324]. It was reported in treatment of echinococcosis for which longterm mebendazole therapy was needed $[36,325,326]$. Hepatotoxicity was also reported in a patient with Gilbert's syndrome (inherited disorder of bilirubin glucuronidation) who was prescribed with mebendazole (200 mg daily for 3 days) to treat pinworm infection [324]. In this patient, a diminished hepatic glucuronidation of mebendazole caused the increase in the level of unconjugated toxic metabolites and the consequent induction of the liver damage [324]. However, in children patients with hydatid disease, even long-term mebendazole treatment (50 mg/kg daily for 9-18 months) was safe without significant side effects [186]. Granulocytopenia, alopecia, pruritus, skin abscess, and arthritis were reported in patients treated with high doses of mebendazole $[36,238,327]$. Importantly, a combined use of mebendazole ( $>500 \mathrm{mg}$ ) and metronidazole ( $>500 \mathrm{mg}$ ) is prohibited because severe and rare fatal adverse events such as Stevens-Johnson syndrome (or toxic epidermal necrosis) may occur [328]. The risk increased with increasing doses of metronidazole but not mebendazole, and there may be a synergistic interaction between mebendazole and metronidazole [328]. In experimental rats, mebendazole has been shown to be a teratogen if given very high doses although not in rabbits [3]. In human patients, mebendazole is contraindicated during pregnancy $[3,34]$.

\section{DRUG RESISTANCE}

\section{Hookworms of veterinary importance}

Large scale use, use of inappropriate doses, and a failure to alternate treatment with other drug classes have caused selection for resistant parasite populations, which render previously effective doses of anthelmintic drugs ineffective [329,330]. This kind of drug resistance has been reported in benzimidazoles, including albendazole and mebendazole. Earlier studies on the drug resistance to benzimidazoles were performed on intestinal nematodes of veterinary importance, in particu- lar, Haemonchus contortus; the drug resistance in this nematode was found to be correlated with a single nucleotide polymorphism at codons 167,198 , or 200 of the $\beta$-tubulin isotype 1 gene $[331,332]$. This single nucleotide polymorphism in the $\beta$-tubulin isotype 1 gene was also found in Ancylostoma caninum [331]. However, a different resistance mechanism, although not yet elucidated, may be present in the drug resistance of intestinal nematodes, for example, in Ancylostoma ceylanicum [333]. The resistance might also arise in various ways, including point mutations or deletion of $\beta$-tubulin isotype 1 or 2, microtubule-associated proteins, or others [334,335].

\section{Human-infecting hookworms}

Regarding human-infecting intestinal nematodes, such as hookworms, the emergence of drug resistance has been suggested by various workers, including Bennett and Guyatt [336]. In treatment of human hookworm (Necator americanus) infections in Mali, mebendazole (500 mg single dose) gave disappointing results $(22.9 \%$ in $\mathrm{CR})$ presumably due to a drug resistance [337]. Thereafter, low efficacies of mebendazole or albendazole against hookworms were repeatedly reported; for example, in Pemba Island, Zanzibar [335,337], Vietnam [338], and Ghana [339]. In Pemba Island, the efficacy of mebendazole (500 mg single dose) against hookworms in schoolchildren had fallen over a period of 5 years, from $22.4 \%$ to $7.6 \%$ in CR and $82.4 \%$ to $52.1 \%$ in ERR, during which time the children were regularly treated [337]. However, molecular studies revealed no evidence for the $\beta$-tubulin mutation at amino acid residue 200 (Phe/Tyr) [335]. In Vietnam, a single (500 mg) or multiple doses of mebendazole (500 mg daily for 3 days) was found to have disappointing efficacy against hookworm infections in children (CR; $38 \%$ in mebendazole single dose group vs 33\% in placebo group) and adults (CR; 26\% in mebendazole 3-day group vs 35\% in placebo group) [338]. Drug resistance was also shown in albendazole in adults; CR was $45 \%$ in single dose albendazole ( $400 \mathrm{mg}$ ) group and 79\% in albendazole 3-day group in comparison with 35\% placebo group [338]. In Ghana, poor efficacy of albendazole (400 mg single dose) was obtained in treatment of hookworms, $61.1 \%$ CR and 81.5\% ERR, presumably due to drug resistance [339]. In $\mathrm{N}$. americanus, isothermal diagnostic assays were developed to target single nucleotide polymorphisms at codons 167, 198 , or 200 of the $\beta$-tubulin isotype 1 gene, to study on the drug resistance [41]. 


\section{Trichuris trichiura}

As to T. trichiura infection, Bennett and Guyatt [336] reviewed literature on the efficacy of albendazole and mebendazole and found that the CR of albendazole (400 mg single dose) was markedly lower in Asia than in Africa, Central and South America (33.3\% vs $61.0 \%$, respectively) probably due to a drug resistance. The low efficacy of mebendazole against $T$. trichiura was again reported in schoolchildren on Pemba Island; mebendazole (500 mg single dose) gave only $22.9 \% \mathrm{CR}$ and $81.0 \%$ ERR [337]. Diawara et al. [340] confirmed different alleles at codon 200 in the $\beta$-tubulin gene (only 1 isotype has been found at this gene in T. trichiura) from T. trichiura worms (Kenya) and eggs (Panama) obtained from children. It was suggested that the gene mutation at codon 200 might be related with the drug resistance [340,341]. Also, a single dose of albendazole $(400 \mathrm{mg}$ ) revealed highly variable efficacies against T. trichiura infection according to different countries, including Cameroon, Ethiopia, India, Tanzania, and Vietnam, with 21.088.9\% CR and 39.2-93.1\% ERR, partly due to drug resistance [342]. The drug resistance of T. trichiura to benzimidazoles was also suggested by Moser et al. [42,43]. They demonstrated that the CR and ERR of T. trichiura by albendazole ( $400 \mathrm{mg}$ single dose) were $38.6 \%$ and $72.6 \%$ in 1995 which decreased to $16.4 \%$ and $43.4 \%$ in 2015 , respectively [43]. In case of mebendazole, its efficacy (500 mg single dose) for T. trichiura infection was $42.1-44.4 \%$ in CR and $66.0-80.7 \%$ in ERR [42]. For a short-term control (4 months) of trichuriasis in schoolchildren, Myanmar, a single dose of albendazole (400 mg) appeared to be not enough, and a long-term MDA ( $>10$ years), increasing albendazole dosage-regimen into 3-day course, or using an alternative drug or drug combination was recommended [46].

\section{Ascaris lumbricoides}

A reduced efficacy of albendazole (400 mg single dose) was also reported in A. lumbricoides in Rwanda for which parasite no drug resistance had been previously recognized [40]. The CR of A. lumbricoides infection in 1 of 12 schools was as low as $35.3 \%$, and the average CR and ERR in 12 schools was $69.9 \%$ and $75.4 \%$, respectively; however, no gene mutation was found at codons 167, 198, and 200 from 4 Ascaris $\beta$-tubulin isotype genes [41]. Reversely, Diawara et al. [341] identified a single nucleotide polymorphism at position 167 of A. lumbricoides $\beta$-tubulin.

\section{Wuchereria bancrofti}

Benzimidazole resistance-associated mutations were also found in the filarial nematode W. bancrofti; some of the microfilariae obtained from albendazole-treated patients revealed mutation at the position 200 of $\beta$-tubulin genotype [343].

\section{Giardia sp.}

In Giardia sp., albendazole resistance was reported which was correlated with cytoskeletal changes but not dependent on mutation at codon 200 in $\beta$-tubulin gene [344].

\section{ANTI-CANCER EFFECTS}

\section{Albendazole}

The use of mammalian cell tubulin as a screen for potential anti-cancer drugs has been well documented [345]. Benzimidazole carbamates were shown to act against L1210 mouse leukemia cells in vitro via inhibition of tubulin polymerization [345]. Albendazole, one of the benzimidazoles, has the activity against parasite as well as mammalian tubulins and was shown to suppress in vitro and in vivo (mice) proliferation of hepatocellular carcinoma cells through inhibiting tubulin polymerization [38,346]. Ovarian [347] and prostate and colorectal cancer cells [348] were also suppressed by treatment with albendazole alone or albendazole plus 2-methoxyestradiol by inhibiting tubulin polymerization. Breast cancer and melanoma cell lines were susceptible to cytotoxic effects of albendazole, and a combined use of albendazole with other antitumor drugs may lead to an effective anti-cancer therapy $[349,350]$. In addition, albendazole was shown to act in vitro as a potent radiosensitizer in metastatic melanoma and small cell lung cancer cell lines [351] and had anti-angiogenesis effects on the cornea [352]. In Ehrlich carcinoma model in mice, albendazole induced oxidative stress promoting DNA fragmentation, triggering apoptosis, and inducing cancer cell death [33]. Further, albendazole exerted its anti-cancer activity in gastric cancer cell lines by disrupting microtubule formation and function to cause mitotic arrest and inducing cancer cell apoptosis [353] or by affecting STAT3 and STAT5 activation by pleiotropic mechanisms [354]. However, the anti-tumor activity of albendazole was cancer cell-type dependent; 13 of 14 human papillomavirus-negative head and neck squamous cell cancer cell lines responded well to albendazole, whereas only 3 of 6 human papillomavirus-positive head and neck squamous cell cancer cell lines responded to albendazole [355]. Albendazole 
Table 6. Clinical trials of albendazole and mebendazole for human cancers

\begin{tabular}{|c|c|c|c|c|c|}
\hline Drug & Type of cancers & $\begin{array}{l}\text { No. of } \\
\text { cases }\end{array}$ & Drug regimen & Effects & References \\
\hline \multirow[t]{14}{*}{ Albendazole } & $\begin{array}{l}\text { Advanced colorectal carcinoma } \\
\text { with liver metastasis }\end{array}$ & 7 & $10 \mathrm{mg} / \mathrm{kg} /$ day $\times 28$ days & $\begin{array}{l}\text { Decrease of CEA }{ }^{\text {a }} \\
\text { Two cases developed neutropenia } \\
\text { and treatment stopped in } 1 \text { case } \\
\text { on day } 14\end{array}$ & [37] \\
\hline & Hepatocellular carcinoma & 1 & $10 \mathrm{mg} / \mathrm{kg} /$ day $\times 19$ days & $\begin{array}{l}\text { Decrease of a-feto protein, but } \\
\text { treatment stopped due to severe } \\
\text { neutropenia }\end{array}$ & \\
\hline & $\begin{array}{l}\text { Mesothelioma/carcinoid tumor in } \\
\text { the liver and pleura }\end{array}$ & 1 & $10 \mathrm{mg} / \mathrm{kg} /$ day $\times 28$ days & WBC counts normal & \\
\hline & Colorectal cancer & 12 & $800 \mathrm{mg} /$ day $\times 7-14$ days & $\begin{array}{l}\text { Phase } 1 \text { clinical trial to determine } \\
\text { maximum tolerable dose of } \\
\text { albendazole }\end{array}$ & [313] \\
\hline & Gastric cancer & 3 & $1,600 \mathrm{mg} /$ day $\times 14$ days & $\begin{array}{l}\text { Neutropenia occurred in } 3 \text { of } 18 \\
\text { patients given daily dose of } \\
2,000 \mathrm{mg} \text { or } 2,400 \mathrm{mg} \text { for } 14 \text { days }\end{array}$ & \\
\hline & Mesothelioma & 3 & $2,000 \mathrm{mg} /$ day $\times 14$ days or & & \\
\hline & Pancreatic cancer & 2 & $2,400 \mathrm{mg} /$ day $\times 14$ days & & \\
\hline & Lung cancer (non-small cell) & 2 & & & \\
\hline & Squamous cell carcinoma & 2 & & & \\
\hline & Ovarian cancer & 2 & & & \\
\hline & Prostate cancer & 2 & & & \\
\hline & Biliary cancer & 2 & & & \\
\hline & Head \& neck cancer and others & 6 & & & \\
\hline & $\begin{array}{l}\text { Malignant diseases, untreatable, } \\
\text { progressive, and fatal }\end{array}$ & 250 & $\begin{array}{l}\text { Phase } 2 \text { clinical trial (albendazole } \\
\text { or mebendazole) }\end{array}$ & $\begin{array}{l}\text { July } 2011 \text { to December 2023, } \\
\text { Dr. Frank Arguello Cancer Clinic, } \\
\text { Mexico }\end{array}$ & [35] \\
\hline \multirow[t]{8}{*}{ Mebendazole } & $\begin{array}{l}\text { Adrenocortical carcinoma with liver } \\
\text { metastasis }\end{array}$ & 1 & 200 mg/day $\times 19$ months & $\begin{array}{l}\text { Tumor regressed, but the disease } \\
\text { progressed after } 24 \text { months } \\
\text { Quality of life satisfactory }\end{array}$ & [370] \\
\hline & $\begin{array}{l}\text { Colon cancer with liver and lung } \\
\text { metastasis }\end{array}$ & 1 & $200 \mathrm{mg} /$ day $\times 42$ days & $\begin{array}{l}\text { Near complete remission of } \\
\text { metastatic lesions in the lungs and } \\
\text { good partial remission in the liver }\end{array}$ & [371] \\
\hline & High-grade glioma & 24 & $\begin{array}{c}\text { Phase } 1 \text { clinical trial } \\
\text { (mebendazole } 500 \text { mg chewable } \\
\text { tablet, } 3 \text { times daily for } 28 \text { days) }\end{array}$ & $\begin{array}{l}\text { April } 2013 \text { to September 2025, } \\
\text { The Johns Hopkins Hospital, USA }\end{array}$ & [35] \\
\hline & High-grade glioma & 21 & $\begin{array}{c}\text { Phase } 1 \text { clinical trial } \\
\text { (mebendazole } 500 \text { mg chewable } \\
\text { tablet, } 3 \text { divided doses with meals) }\end{array}$ & $\begin{array}{l}\text { May } 2016 \text { to June 2022, The Johns } \\
\text { Hopkins All Children's Hospital, } \\
\text { USA }\end{array}$ & [35] \\
\hline & $\begin{array}{l}\text { Low and high-grade pediatric } \\
\text { glioma }\end{array}$ & 36 & $\begin{array}{c}\text { Phase } 1 \text { clinical trial } \\
\text { (mebendazole } 50-200 \mathrm{mg} / \text { day for } \\
48-70 \text { weeks) }\end{array}$ & $\begin{array}{l}\text { October } 2013 \text { to April 2020, Cohen } \\
\text { Children's Medical Center of New } \\
\text { York, USA }\end{array}$ & [35] \\
\hline & $\begin{array}{l}\text { Malignant diseases, untreatable, } \\
\text { progressive, and fatal }\end{array}$ & 250 & $\begin{array}{l}\text { Phase } 2 \text { clinical trial (albendazole } \\
\text { or mebendazole) }\end{array}$ & $\begin{array}{l}\text { July } 2011 \text { to December 2023, Dr. } \\
\text { Frank Arguello Cancer Clinic, } \\
\text { Mexico }\end{array}$ & [35] \\
\hline & Colorectal cancer (stage 4) & 40 & $\begin{array}{c}\text { Phase } 3 \text { clinical trial } \\
\text { (mebendazole as adjuvant } \\
\text { treatment) }\end{array}$ & $\begin{array}{l}\text { April } 2019 \text { to December 2028, } \\
\text { Sherief Abd-Elsalam, Egypt }\end{array}$ & [35] \\
\hline & Variable cancers & 207 & $\begin{array}{l}\text { Phase } 3 \text { clinical trial } \\
\text { (mebendazole } 100 \mathrm{mg} / \text { day) }\end{array}$ & $\begin{array}{l}\text { May } 2017 \text { to May 2022, Care } \\
\text { Oncology Clinic, UK }\end{array}$ & [35] \\
\hline
\end{tabular}

${ }^{\mathrm{a} C E A}$, carcinoembryonic antigen.

also showed anti-tumor effects on cutaneous squamous cell carcinoma cells via regulation of endoplasmic reticulum stress and cancer stemness [356].

Compared with many experimental in vitro and in vivo (mice) studies, clinical application of albendazole in treatment of cancer patients has been limited. A pilot clinical study was performed in 9 patients with advanced colorectal carcinoma with liver metastasis $(n=7)$, hepatocellular carcinoma $(n=1)$, 
or mesothelioma/carcinoid tumor in the liver and pleura $(\mathrm{n}=1)$ [37] (Table 6). Out of 7 patients in whom serum tumor markers could be measured, albendazole treatment $(10 \mathrm{mg} / \mathrm{kg}$ daily for 28 days) resulted in a decrease in carcinoembryonic antigen (CEA) or $\alpha$-feto protein (AFP) levels in 2 patients, and these markers were stabilized in 3 patients [37]. In the remaining 2 patients, CEA or AFP levels, after initial stabilization during 5-10 days, began to increase again [37]. Long-term (28 days) treatment with albendazole was well tolerated, and there were no significant changes in hematological, kidney or liver function tests [37]. However, 3 of the 9 patients treated with albendazole developed severe neutropenia which was probably contributory to the death of 1 patient [37]. Another clinical study reported was a phase 1 clinical trial involving 36 solid (colorectal, gastric, mesothelial, or other) tumor patients refractory to conventional anti-cancer therapies, and different dosage regimens of albendazole (800 $\mathrm{mg}$ daily for 7-14 days, $1,600 \mathrm{mg}$ daily for 14 days, 2,000 mg daily for 14 days, or 2,400 mg daily for 14 days) were tried [313]. The maximum tolerated dose of oral albendazole found in these patients was 2,400 mg per day (1,200 mg b.i.d.), and the recommended dose for further study was $2,400 \mathrm{mg}$ daily for 14 days in a 21day cycle [313]. However, 3 of 18 patients given 2,000-2,400 mg daily for 14 days developed neutropenia and other myelosuppression signs [313]. There is an on-going clinical trial for use of albendazole and mebendazole in Mexico (July 2011 to December 2023) for 250 patients who are considered untreatable, progressive, and fatal [35].

Myelosuppression, including neutropenia, leukopenia, lymphopenia, thrombocytopenia, and anemia, were seen in patients given albendazole at the daily dose of 2,400 $\mathrm{mg}$ which were found to be the main dose limiting toxicity [313]. Because of this toxicity limitation, mebendazole rather than albendazole has been more popularly recommended as a benzimidazole anti-cancer agent [34]. In addition, fenbendazole, a popular anthelmintic used in dogs and other animal species, has been proposed as a new potential microtubule interfering agent that displays anti-neoplastic activity in humans [357]. Large-scale clinical evidence is lacking but it has been mentioned that a human lung cancer survivor used fenbendazole for treatment of late-stage small cell lung cancer; however, the safety of fenbendazole for human use needs to be clarified [35].

Low solubility of albendazole in water is one of the main obstacles for use as an anti-parasitic as well as anti-cancer drug.
Among various trials to overcome this problem, the most successful approach is to formulate or conjugate it into nanostructures or nanoformulations, in practice of improving aqueous solubility [358]. Albendazole-cyclodextrin complex, M1 albendazole, albumin nanoparticles, chitosan nanoparticles, solid lipid nanoparticles, PLGA nanoparticles, albendazole-copper oxide nanoparticles, and solid polymeric nanoparticles are examples of so far designed nanoformulations of albendazole [358,359].

\section{Mebendazole}

The anti-tumor activity of mebendazole was first tested by Mukhopadhyay et al. [360] by in vitro and in vivo (mice) experiments using human lung cancer cell lines. Mebendazole was a potent inhibitor of tumor cell growth with little toxicity to normal fibroblasts (W138) and human umbilical vein endothelial cells [360]. At the same time, Sasaki et al. [361] found that mebendazole actively inhibited microtubule assembly and spindle formation of human non-small cell lung cancer cells which led to mitotic arrest and death of cancer cells. Anti-tumor activity of mebendazole also seemed to be due to a decrease in angiogenesis of cancers [361]. The anti-tumor activities of mebendazole were also demonstrated in human adrenocortical carcinoma cells implanted into nude mice [362] and chemoresistant human melanoma cells [363]. Mebendazole was suggested to have advantages in a preclinical study of brain glioma-mouse model; mebendazole but not albendazole was able to significantly increase survival of mice having glioblastoma multiforme [364]. Five colon cancer cell lines and 3 non-malignant intestinal epithelial cell lines were tested for response to mebendazole, and selective anti-cancer activity was found [365]. The mebendazole activity against brain tumor cells (glioblastoma cell lines) was proven to be caused by inhibiting microtubule functions of the cells $[366,367]$, and the survival of tumor-cell recipient mice was significantly increased by mebendazole treatment [366]. Mebendazole was also shown to be useful as a drug candidate for ovarian cancer therapy [368] as well as to synergize with docetaxel for prostate cancer treatment [369]. Collectively, mebendazole has been shown to not only exhibit direct cytotoxic activity, but also synergize with ionizing radiation and different chemotherapeutic agents to stimulate anti-tumoral immune responses which result in reduction or complete arrest of tumor growth, marked decrease of metastatic spread, and improvement of survival [34]. 
Many clinical trials with mebendazole are currently on-going [35]; however, published documents in treatment of cancer patients have so far been limited only to 2 case reports [370,371] (Table 6). The first report was published by Dobrosotskaya et al. [370] in the United States. The patient was a 48-year-old man with adrenocortical carcinoma with liver metastasis, and conventional treatments with mitotane, 5-fluorouracil, streptozotocin, bevacizumab, and radiation therapy failed and were intolerable [370]. Mebendazole (200 mg daily for 19 months) brought about regression of hepatic metastatic lesions with subsequent stability for 19 months, although the disease progressed after 24 months; however, the patient had no clinically adverse effects, and the quality of life was satisfactory [370]. A combined use of mebendazole with other cytotoxic drugs was suggested to have synergistic effects [370]. The second case was a colon cancer patient with liver and lung metastases; the patient was treated conventionally with capecitabine, oxaliplatin, and becacizumab but failed largely due to oxaliplatin-induced neuropathy [371]. Mebendazole therapy (200 mg daily) was continued for 42 days, and there were near complete remission of the metastases in the lungs and lymph nodes and a good partial remission in the liver [371]. Because of elevation of liver enzymes, mebendazole was stopped temporarily and then reintroduced at half dose; liver enzymes slowly decreased and the patient reported no adverse effects from mebendazole [371]. For future dosing and efficacies of mebendazole, at least 5 clinical trials are on-going in several countries, including 2 phase 1 clinical trials using mebendazole (500 mg chewable tablets, 3 times daily) on 24 and 21 high-grade glioma patients by The Johns Hopkins Hospital (NCT02644291, April 2013 to September 2025) and by The Johns Hopkins All Children's Hospital, USA (NCT 0244291, May 2016 to June 2022), respectively, 1 phase 1/2 trial on 36 low- and high-grade glioma patients using mebendazole (50-200 mg/kg for 70 and 48 weeks, respectively) by Cohen Childrens' Medical Center of New York, USA (NCT01837862, October 2013 to April 2020), 1 phase 2 trial on 250 patients with variable malignant diseases using mebendazole, albendazole or other drugs by Dr. Frank Arguello Cancer Clinic, Mexico (NCT02366884, July 2011 to December 2023), and 2 phase 3 trials using mebendazole as adjuvant treatment for 40 patients with stage 4 colorectal cancer in Egypt (NCT03925662, April 2019 to December 2028) and using mebendazole (100 mg daily for undefined duration) for treatment of 207 cancer patients by Care Oncology Clinic, UK (NCT02201381, April 2017 to May 2022) [35]. These trials are expected to bring about fruitful results on usefulness of mebendazole as a repurposed anti-cancer drug.

\section{CONCLUSIONS AND PERSPECTIVES}

Albendazole and mebendazole are highly useful broadspectrum anti-parasitic (anti-fungal) as well as anti-cancer agents. These drugs have been widely used for treatment of human intestinal helminthiases (nematodes and cestodes), tissue helminthiases (nematodes and cestodes), filarial nematode infections, liver and intestinal trematode infections, and some kinds of protozoan infections. Recently, these drugs are highlighted because of their anti-cancer activities in vitro and in vivo of animals, and a few clinical anti-cancer trials have been documented. Further trials should be performed for their use as anti-cancer agents. Albendazole and mebendazole are highly safe if used in recommended doses as anti-parasitic agents. However, attention should be paid because hepatic toxicity may rarely occur in patients administered with only a single dose of albendazole. Increasing reports of drug resistance in parasites against albendazole and mebendazole are new emerging issues.

\section{ACKNOWLEDGMENT}

We are grateful to the staff of Institute of Parasitic Diseases, Korea Association of Health Promotion, Seoul, Korea who helped this study. We dedicate this review article to late Prof. Emer. HanJong Rim, Korea University, Seoul, Korea, a pioneer of anthelmintics and parasitology research, who recently passed away.

\section{CONFLICT OF INTEREST}

We have no conflict of interest related to this study.

\section{REFERENCES}

1. Theodorides VJ, Gyurik RJ, Kingsbury WD, Parish RC. Anthelmintic activity of albendazole against liver flukes, tapeworms, lung and intestinal roundworms. Experientia 1976; 32: 702703. https://doi.org/10.1007/BF01919842

2. Pene P, Mojon M, Garin JP, Coulaud JP, Rossignol JF. Albendazole: a new broad spectrum anthelmintic. Double-blind multicenter clinical trial. Am J Trop Med Hyg 1982; 31: 263-266. https://doi.org/10.4269/ajtmh.1982.31.263

3. Dayan AD. Albendazole, mebendazole and praziquantel. Review 
of non-clinical toxicity and pharmacokinetics. Acta Trop 2003; 86: 141-159. https://doi.org/10.1016/S0001-706X(03)00031-7

4. Brugmans JP, Theinpont DC, Wijngaarden IV, Vanparijs OF, Schuermans VL, Lauwers HL. Mebendazole in enterobiasis. Radiochemical and pilot clinical study in 1,278 subjects. JAMA 1971; 217: 313-316. https://doi.org/10.1001/jama.1971.03190030039008

5. Pawluk SA, Roels CA, Wilby KJ, Ensom MHH. A review of pharmacokinetic drug-drug interactions with the anthelmintic medications albendazole and mebendazole. Clin Pharmacokinet 2015; 54: 371-383. https://doi.org/10.1007/s40262-015-0243-9

6. Edwards G, Brechenridge AM. Clinical pharmacokinetics of anthelmintic drugs. Clin Pharmacokinet 1988; 15: 67-93. https:// doi.org/10.2165/00003088-198815020-00001

7. Kern P. Echinococcus granulosus infection: clinical presentation, medical treatment and outcome. Langenbecks Arch Surg 2003; 388: 413-420. https://doi.org/10.1007/s00423-003-0418-y

8. Chai JY, Hong ST. Chemotherapy of intestinal nematode infections. J Korean Soc Chemother 1985; 3: 119-129.

9. Chai JY. Recent advances in the use of anthelmintics for treating nematode infections. Infect Chemother 2011; 43: 26-35 (in Korean). https://doi.org/10.3947/ic.2011.43.1.26

10. Keiser J, Utzinger J. The drugs we have and the drugs we need against major helminth infections. Adv Parasitol 2010; 73: 197230. https://doi.org/10.1016/S0065-308X(10)73008-6

11. Hong ST. Albendazole and praziquantel: review and safety monitoring in Korea. Infect Chemother 2018; 50: 1-10. https:// doi.org/10.3947/ic.2018.50.1.1

12. Jamet D, Quinio D, Moalic E, Ianotto JC, Dalbies F, Guillerm G, Marion V, Berthou C, Nevez G. Systemic microsporidiosis and toxoplasmosis in a patient with Tlymphocytic leukemia. Med Mal Infect 2009; 39: 406-408 (in French). https://doi.org/10.1016/ j.medmal.2008.10.018

13. Rim HJ, Joo KH, Lee JS, Wang JS. Anthelmintic effects of albendazole (Zentel ${ }^{\circledR}$ ) against helminthic infections. Korean J Rural Med 1984; 9: 67-73 (in Korean). https://www.koreascience.or.kr/article/JAKO198431462787922.page

14. Pungpark S, Bunnag D, Harinasuta T. Albendazole in the treatment of opisthorchiasis and concomitant intestinal helminthic infections. Southeast Asian J Trop Med Public Health 1984; 15: 44-50.

15. Keiser J, Utzinger J. Chemotherapy for major food-borne trematodes: a review. Expert Opin Pharmacother 2004; 5: 17111726. https://doi.org/10.1517/14656566.5.8.1711

16. Fan PC, Wu CC, Huang P, Yen CW. Determination of the minimum effective dosages of praziquantel, albendazole, and mebendazole against Clonorchis sinensis infection in rats. Kaohsiung J Med Sci 2005; 21: 448-451. https://doi.org/10.1016/S1607551X(09)70149-4

17. Khan W, Iqbal M, Dad O. Have we forgotten the threat posed by fascioliasis? A potential threat to public health. Iran J Public Health 2020; 49: 814-815.

18. Xu LL, Jiang B, Duan JH, Zhuang SF, Liu YC, Zhu SQ, Zhang LP, Zhang HB, Xiao SH, Zhou XN. Efficacy and safety of pra- ziquantel, tribendimidine and mebendazole in patients with co-infection of Clonorchis sinensis and other helminths. PLoS Negl Trop Dis 2014; 8: e3046. https://doi.org/10.1371/journal. pntd.0003046

19. Jaroonvesama N, Charoenlarp K, Cross JH. Treatment of Opisthorchis viverrini with mebendazole. Southeast Asian J Trop Med Public Health 1981; 12: 595-597.

20. Dugernier T, Geubel A, Bigaignon G, Cesbron JY, Coche E. Human fascioliasis: cure by mebendazole? A case report. Gastroenterol Clin Biol 1986; 10: 513-516.

21. Rim HJ, Joo KH, Park HS. Anthelmintic effects of albendazole against Taenia saginata and Taenia solium infections. J Korean Soc Chemother 1989; 7: 29-39.

22. Takayanagui OM, Odashima NS, Bonato PS, Lima JE, Lanchote VL. Medical management of neurocysticercosis. Expert Opin Pharmacother 2011; 12: 2845-2856. https://doi.org/10.1517/1 4656566.2011.634801

23. Steinmann P, Utzinger J, Du ZW, Jiang JY, Chen JX, Hattendorf J, Zhou H, Zhou XN. Efficacy of single-dose and triple-dose albendazole and mebendazole against soil-transmitted helminths and Taenia spp.: a randomized controlled trial. PLoS One 2011; 6: e25003. https://doi.org/10.1371/journal.pone.0025003

24. Tamarozzi F, Nicoletti GJ, Neumayr A, Brunetti E. Acceptance of standardized ultrasound classification, use of albendazole, and long-term follow-up in clinical management of cystic echinococcosis: a systematic review. Curr Opin Infect Dis 2014; 27: 425-431. https://doi.org/10.1097/QCO.0000000000000093

25. Qavi A, Garg RK, Malhotra HS, Jain A, Kumar N, Malhotra KP, Srivastava PK, Verma R, Sharma PK. Disseminated cysticercosis: clinical spectrum, Toll-like receptor-4 gene polymorphisms and role of albendazole. Medicine 2016; 95: e4882. https://doi. org/10.1097/MD.0000000000004882

26. Molina JM, Oksenhendler E, Beauvais B, Sarfati C, Jaccard A, Derouin F, Modaï J. Disseminated microsporidiosis due to Septata intestinalis in patients with AIDS: clinical features and response to albendazole therapy. J Infect Dis 1995; 171: 245-249. https://doi.org/10.1093/infdis/171.1.245

27. Sak B, Brdíčková K, Holubová N, Květoňová D, Hlásková L, Kváč M. Encephalitozoon cuniculi genotype III evinces a resistance to albendazole treatment in both immunodeficient and immunocompetent mice. Antimicrob Agents Chemother 2020; 64: e00058-20. https://doi.org/10.1128/AAC.00058-20

28. Darlan DM, Hartanto SJ, Rozi MF. The comparison of efficacy and side effect between albendazole and metronidazole in the management of giardiasis: a systematic review and meta-analysis. EuroMeditter Biomed J 2020; 15: 191-196. https://doi.org/ 10.3269/1970-5492.2020.15.45

29. Palos I, Moo-Puc R, Vique-Sánchez JL, Benítez-Cardoza CG, Monge A, Villalobos-Rocha JC, Paz-Gonzalez AD, Rivera G. Esters of quinolone-7-carboxylate-1,4-di-N-oxide as Trichomonas vaginalis triosephosphate isomerase inhibitors. Acta Pharm 2021; 71: 485-495. https://doi.org/10.2478/acph.2021-0032

30. Sears SD, O'hare J. In vitro susceptibility of Trichomonas vagina- 
lis to 50 antimicrobial agents. Antimicrobial Agents Chemother 1988; 32: 144-146. https://doi.org/10.1128/AAC.32.1.144

31. Cedillo-Rivera R, Muñoz O. In-vitro susceptibility of Giardia lamblia to albendazole, mebendazole and other chemotherapeutic agents. J Med Microbiol 1992; 37: 221-224. https://doi. org/10.1099/00222615-37-3-221

32. Patziarka P, Bouche G, Meheus L, Sukhatme V, Sukhatme VP. Repurposing drugs in oncology (ReDO)-mebendazole as an anti-cancer agent. Ecancermedicalscience 2014; 8: 443. https:// doi.org/10.3332/ecancer.2014.44332.

33. Castro LSEPW, Kviecinski MR, Ourique F, Parisotto EB, Grinevicius VMAS, Correia JFG, Filho DW, Pedrosa RC. Albendazole as a promising molecule for tumor control. Radix Biol 2016; 10: 90-99. https://doi.org/10.1016/j.redox.2016.09.013

34. Guerini $\mathrm{AE}$, Triggiani $\mathrm{L}$, Maddalo $\mathrm{M}$, Bonù $\mathrm{ML}$, Frassine $\mathrm{F}$, Baiguini A, Alghisi A, Tomasini D, Borghetti P, Pasinetti N, Bresciani R, Magrini SM, Buglione M. Mebendazole as a candidate for drug repurposing in oncology: an extensive review of current literature. Cancers 2019; 11: 1284. https://doi.org/10.3390/ cancers 11091284

35. Son DS, Lee ES, Adunyah SE. The antitumor potentials of benzimidazole anthelmintics as repurposing drugs. Immun Netw 2020; 20: e29. https://doi.org/10.4110/in.2020.20.e29

36. Braithwaite PA, Thomas RJS, Thompson RCA. Hydatid disease: the alveolar variety in Australia. A case report with comment on the toxicity of mebendazole. Aust N Z J Surg 1985; 55: 519523. https://doi.org/10.1111/j.1445-2197.1985.tb00935.x

37. Morris DL, Jourdan JL, Pougholami MH. Pilot study of albendazole in patients with advanced malignancy. Oncology 2001; 61: 42-46. https://doi.org/10.1159/000055351

38. Pourgholami MH, Woon L, Almajd R, Akhter J, Bowery P, Morris DL. In vitro and in vivo suppression of growth of hepatocellular carcinoma cells by albendazole. Cancer Lett 2001; 165: 43-49. https://doi.org/10.1016/S0304-3835(01)00382-2

39. Moon SY, Baek YH, Lee SW. Drug induced liver injury by prophylactic administration of albendazole. Korean J Gastroenterol 2019; 73: 360-364 (in Korean). https://doi.org/10.4166/kjg.2019.73.6.360 40. Krücken J, Fraundorfer K, Mugisha JC, Ramünke S, Sifft KC, Geus D, Habarugira F, Ndoli J, Sendegeya A, Mukampunga C, Bayingana C, Aebischer T, Demeler J, Gahutu JB, Mockenhaupt FP, von Samson-Himmelstjerna G. Reduced efficacy of albendazole against Ascaris lumbricoides in Rwandan schoolchildren. Int J Parasitol Drugs Drug Resist 2017; 7: 262-271. https://doi. org/10.1016/j.ijpddr.2017.06.001

41. Rashwan N, Bourguinat C, Keller K, Gunawardena NK, de Silva $\mathrm{N}$, Prichard R. Isothermal diagnostic assays for monitoring single nucleotide polymorphisms in Necator americanus associated with benzimidazole drug resistance. PLoS Negl Trop Dis 2016; 10: e0005113. https://doi.org/10.1371/journal.pntd.0005113

42. Moser W, Schindler C, Keiser J. Drug combinations against soiltransmitted helminth infections. Adv Parasitol 2019; 103: 91115. https://doi.org/10.1016/bs.apar.2018.08.002

43. Moser W, Schindler C, Keiser J. Efficacy of recommended drugs against soil transmitted helminths: systematic review and network meta-analysis. BMJ 2017; 358: j4307. https://doi.org/10.1136/bmj. j4307

44. Soukhathammavong PA, Sayasone S, Phongluxa K, Xayaseng V, Utzinger J, Vounatsou P, Hatz C, Akkhavong K, Keiser J, Odermatt P. Low efficacy of single-dose albendazole and mebendazole against hookworm and effect on concomitant helminth infection in Lao PDR. PLoS Negl Trop Dis 2012; 6: e1417. https:// doi.org/10.1371/journal.pntd.0001417

45. World Health Organization. WHO Model Prescribing Information: Drugs Used in Parasitic Diseases. 2nd ed. World Health Organization. Geneva, Switzerland. 1995, pp 1-146.

46. Chai JY, Sohn WM, Hong SJ, Jung BK, Hong S, Cho S, Park JB, Kim IS, Kim S, Lee KH, Jeoung HG, Htoon TT, Tin HH. Effect of mass drug administration with a single dose of albendazole on Ascaris lumbricoides and Trichuris trichiura infection among schoolchildren in Yangon Region, Myanmar. Korean J Parasitol 2020; 58: 195-200. https://doi.org/10.3347/kjp.2020.58.2.195

47. Chaia G, Sales da Cunha A. Therapeutic action of mebendazole (R 17,635) against human helminthiasis. Fôlha Med 1971; 63: 843-852.

48. Chavarría AP, Swartzwelder JC, Villarejos VM, Zeledón R. Mebendazole, an effective broad-spectrum anthelmintic. Am J Trop Med Hyg 1973; 22: 592-595. https://doi.org/10.4269/ajtmh.1973.22.592

49. Seo BS, Cho SY, Chai JY. Reduced single dose of mebendazole in treatment of Ascaris lumbricoides infection. Korean J Parasitol 1978; 16: 21-25. http://dx.doi.org/10.3347/kjp.1978.16.1.21

50. Abadi K. Single dose mebendazole therapy for soil-transmitted nematodes. Am J Trop Med Hyg 1985; 34: 129-133. https:/doi. org/10.4269/ajtmh.1985.34.129

51. Pene P, Coulaud JP, Soula G, Rossignol JF, Monges P, Chaudet H. Le Zentel ${ }^{\circledR}$ dans traitement des helminthiases intestinales en Afrique de l'Ouest. Méd Afr Noire 1982; 29: 43-48 (in French).

52. Soula G, Stopathis RM. Le Zentel ${ }^{\circledR}$ dans le traitement des nématodoses intestinales en République Centrafricaine. Méd Afr Noire 1982; 29: 29-32 (in French).

53. Horton J. Albendazole: a review of anthelmintic efficacy and safety in humans. Parasitology 2000; 121 (suppl): 113-132. https://doi. org/10.1017/s0031182000007290

54. Seo BS, Cho SY, Kang SY, Chai JY. Anthelmintic efficacy of methyl-5-benzoylbenzimidazle-2-carbamate (mebendazole) against multiple helminthic infections. Korean J Parasitol 1977; 15: 11-16. http://dx.doi.org/10.3347/kjp.1977.15.1.11

55. Sinniah B, Sinniah D, Dissanaike AS. Treatment of intestinal nematodes with single dose treatment of oxantel-pyrantel pamoate plus mebendazole. In Asian Parasite Control Organization Research Group ed, Collected Papers on the Control of Soil-Transmitted Helminthiases by Asian Parasite Control Organization (APCO). Tokyo, Japan. The Asian Parasite Control Organization 1980, pp 321-325.

56. Coulaud JP, Duchatelle C, Rouvillois A, Deluol AM. Le Zentel ${ }^{\circledR}$ dans le traitement des helminthiases intestinales, au Niger, en Guinée et à Paris. Méd Afr Noire 1982; 29: $41-42$ (in French). 
57. Kim CH. Clinical trials of mebendazole (Vermox) on Ascaris and Trichuris infection. Chungnam Med J 1975; 2: 207-211 (in Korean).

58. Seo BS, Lee SH, Chai JY, Hong ST, Hong SJ. Efficacy of mebendazole in treatment and control of trichuriasis in Korea. Korean J Parasitol 1983; 21: 95-101. http://dx.doi.org/10.3347/kjp.1983.21.1.95

59. Henriquez-Camacho C, Gottuzzo E, Echevarria J, White AC Jr, Terashima A, Samalvides F, Pérez-Molina JA, Plana MN. Ivermectin versus albendazole or thiabendazole for Strongyloides stercoralis infection. Cochrane Datab Syst Rev 2016; 2016: CD007745. http://doi.org/10.1002/14651858.CD007745.pub3

60. Hong SJ, Han JH. A case of Strongyloides stercoralis infection. Korean J Parasitol 1999; 37: 117-120. https://doi.org/10.3347/kjp. 1999.37.2.117

61. Echazú A, Juarez M, Vargas PA, Cajal SP, Cimino RO, Heredia V, Caropresi S, Paredes G, Arias LM, Abril M, Gold S, Lammie P, Krolewiecki AJ. Albendazole and ivermectin for control of soiltransmitted helminths in an area with high prevalence of Strongyloides stercoralis and hookworm in northwestern Argentina: a community-based pragmatic study. PLoS Negl Trop Dis 2017; 11: e0006003. http://doi.org/10.1371/journal.pntd.0006003

62. Chai JY, Hong ST, Sohn WM, Lee SH. Anthelmintic effect of albendazole (Alzental@) on human intestinal nematodes. J Korean Soc Chemother 1986; 4: 86-88 (in Korean).

63. St Georgiev V. Chemotherapy of enterobiasis (oxyuriasis). Expert Opin Pharmacother 2001; 2: 267-275. https://doi.org/10. 1517/14656566.2.2.267

64. Cho SY, Ahn YR, Ryang YS, Seo BS. Evaluation of anthelmintic treatment on Enterobius vermicularis infection in highly endemic population by prolonged observation. Korean J Parasitol 1977; 15: 100-108. http://dx.doi.org/10.3347/kjp.1977.15.2.100

65. Hong ST, Chai JY, Cho SY, Seo BS, Yun CK. Efficacy of repeated chemotherapy in control of Enterobius vermicularis infection. Seoul J Med 1979; 20: 163-168. https://snucm.elsevierpure.com/ en/publications/efficacy-of-repeated-chemotherapy-in-controlof-enterobius-vermic

66. Steinmann P, Zhou XN, Du ZW, Jiang JY, Xiao SH, Wu ZX, Zhou $\mathrm{H}$, Utzinger J. Tribendimidine and albendazole for treating soil-transmitted helminths, Strongyloides stercoralis and Taenia spp.: open-label randomized trial. PLoS Negl Trop Dis 2008; 2: e322. https://doi.org/10.1371/journal.pntd.0000322

67. Soh CT, Lee BH, Min DY, Chang SJ, Lee JH. Clinical trial of Vermox (mebendazole), a new broadspectrum anthelmintic. Yonsei Rep Trop Med 1974; 5: 148-152.

68. Chavarria AP, Villarejos VM, Zeledón R. Mebendazole in the treatment of taeniasis solium and taeniasis saginata. Am J Trop Med Hyg 1977; 26: 118-120. https://doi.org/10.4269/ajtmh.1977.26.118

69. Chai JY. Praziquantel treatment in trematode and cestode infections: an update. Infect Chemother 45: 32-43. https://doi. org/10.3947/ic.2013.45.1.32

70. Rossignol JF, Maisonneuve H. Albendazole: placebo-controlled study in 870 patients with intestinal helminthiasis. Trans R Soc Trop Med Hyg 1983; 77: 707-711. https://doi.org/10.1016/0035-
9203(83)90211-0

71. Keystone JS, Murdocch JK. Mebendazole. Ann Intern Med 1979; 91: 582-586. https://doi.org/10.7326/0003-4819-91-4582

72. Kong L, Peng HJ. Current epidemic situation of human toxocariasis in China. Adv Parasitol 2020; 109: 433-448. https://doi. org/10.1016/bs.apar.2020.01.016

73. Nicholas WL, Stewart AC. The action of benzimidazoles on the larval stage of Toxocara canis in the mouse. Ann Trop Med Parasitol 1979; 73: 57-62. https://doi.org/10.1080/00034983.1979. 11687227

74. Stürchler D, Schubarth P, Gualzata M, Gottstein B, Oettli A. Thiabendazole vs. albendazole in treatment of toxocariasis: a clinical trial. Ann Trop Med Parasitol 1989; 83: 473-478. https:// doi.org/10.1080/00034983.1989.11812374

75. Barisani-Asenbauer T, Maca SM, Hauff W, Kaminski SL, Domanovits $\mathrm{H}$, Theyer I, Auer H. Treatment of ocular toxocariasis with albendazole. J Ocul Pharmacol Therapeut 2001; 17: 287294. https://doi.org/10.1089/108076801750295317

76. Anonymous. Drugs for parasitic infections. Med Lett Drugs Ther 2004; 1189: 1-12.

77. Singer OC, Conrad F, Jahnke K, Hattingen E, Auer H, Steinmetz H. Severe meningoencephalomyelitis due to CNS-toxocarosis. J Neurol 2011; 258: 696-698. https://doi.org/10.1007/s00415010-5807-x

78. Feske SK, Goldberg M, Dudzinski DM, Gonzalez RG, Kovach AE. Case 29-2015: a 38-year-old pregnant woman with headache and visual symptoms. N Engl J Med 2015; 373: 11541164. https://doi.org/10.1056/NEJMcpc1404335

79. Melliou M, Mavridis IN, Pyrgelis ES, Agapiou E. Toxocariasis of the nervous system. Acta Parasitol 2020; 65: 291-299. https:// doi.org/10.2478/s11686-019-00166-1

80. Hombu A, Yoshida A, Kikuchi T, Nagayasu E, Kuroki M, Maruyama $H$. Treatment of larva migrans syndrome with longterm administration of albendazole. J Microbiol Immunol Infect 2019; 52: 100-105. https://doi.org/10.1016/j.jmii.2017.07.002

81. Magnaval JF. Comparative efficacy of diethylcarbamazine and mebendazole for treatment of human toxocariasis. Parasitology 1995; 110: 529-533. https://doi.org/10.1017/S0031182000065240

82. Coulaud JP, Binet D, Voyer C, Samson C, Moreau G, Rossignol JF. Treatment of cutaneous larva migrans "Larbish' with albendazole: report of 18 cases. Bull Soc Pathol Exot Filiales. 1982; 75: 534-537 (in French).

83. Thadchanamoorthy V, Dayasiri K. Cutaneous larvae migrans infestation over buttocks and perianal region: a case series of five toddlers from Sri Lanka and literature review. Cureus 2020; 12: e11335. https://doi.org/10.7759/cureus.11335

84. Mulia RC, Djawad K, Adriani A, Idrus I. Office-made 4\% albendazole cream is an effective alternative therapy for cutaneous larva migrans: a report of three cases. Serbian J Dermatol Venerol 2020; 12: 9-13. https://doi.org/10.2478/sjdv-2020-0002

85. Tan SK, Liu TT. Cutaneous larva migrans complicated by Löffler syndrome. Arch Dermatol 2010; 146: 210-212. https://doi. 
org/10.1001/archdermatol.2009.392

86. Sohn WM, Chai JY. Chapter 63. Anisakiosis (Anisakidosis). Part 4. Parasitic zoonoses. In eds, Palmer SR, Soulsby L, Torgerson P, Brown DWG. Oxford Textbook of Zoonoses: Biology, Clinical Practice, and Public Health Control (2nd ed.). Oxford Univ Press. London, UK. 2011, pp 776-788.

87. Lim H, Jung BK, Cho J, Yooyen T, Shin EH, Chai JY. Molecular diagnosis of cause of anisakiasis in humans, South Korea. Emerg Infect Dis 2015; 21: 342-344. https://doi.org/10.3201/ eid2102.140798

88. Moore DAJ, Girdwood RWA, Chiodini PL. Treatment of anisakiasis with albendazole. Lancet 2002; 360: 54. https://doi.org/ 10.1016/S0140-6736(02)09333-9

89. Pacios E, Arias-Diaz J, Zuloaga J, Gonzalez-Armengol J, Villarroel P, Balibrea JL. Albendazole for the treatment of anisakiasis ileus. Clin Infect Dis 2005; 41: 1825-1826. https://doi.org/10.1086/498309

90. Baptista-Fernandes T, Rodrigues M, Castro I, Paixão P, PintoMarques P, Roque L, Belo S, Ferreira PM, Mansinho K, Toscano C. Human gastric hyperinfection by Anisakis simplex: a severe and unusual presentation and a brief review. Int J Infect Dis 2017; 64: 38-41. https://doi.org/10.1016/j.ijid.2017.08.012

91. Guardone L, Armani A, Nucera D, Costanzo F, Mattiucci S, Bruschi F. Human anisakiasis in Italy: a retrospective epidemiological study over two decades. Parasite 2018; 25: 41. https:// doi.org/10.1051/parasite/2018034

92. Maggi P, Caputi-Lambrenghi O, Scardigno A, Scoppetta L, Saracino A, Valente M, Pastore G, Angarano G. Gastrointestinal infection due to Anisakis simplex in southern Italy. Eur J Epidemiol 2000; 16: 75-78. https://doi.org/10.1023/a:1007617002972

93. Moschella CM, Mattiucci S, Mingazzini P, De Angelis G, Assenza M, Lombardo F, Monaco S, Paggi L, Modini C. Intestinal anisakiasis in Italy: case report. J Helminthol 2004; 78: 271-273. https://doi.org/10.1079/JOH2004237

94. Gómez-Mateos M, Arrebola F, Navarro MC, Romero MC, González JM, Valero A. Acute anisakiasis: pharmacological evaluation of various drugs. Dig Dis Sci 2021; 66: 105-113. https://doi.org/10.1007/s10620-020-06144-2

95. McCracken RO. Efficacy of mebendazole and albendazole against Trichinella spiralis in mice. J Parasitol 1978; 64: 214-219. https://doi.org/10.2307/3279659

96. Fourestié V, Bougnoux ME, Ancelle T, Liance M, Roudot-Thoraval F, Naga H, Pairon-Pennachioni M, Rauss A, Lejonc JL. Randomized trial of albendazole versus tiabendazole plus flubendazole during an outbreak of human trichinellosis. Parasitol Res 1988; 75: 36-41. https://doi.org/10.1007/BF00931188

97. Cabié A, Bouchaud O, Houzé S, Khuong MA, Ruggeri C, Ancelle T, Matheron S, Coulaud JP. Albendazole versus thiabendazole as therapy for trichinosis: a retrospective study. Clin Infect Dis 1996; 22: 1033-1035. https://doi.org/10.1093/clinids/22.6.1033

98. Gottstein B, Pozio E, Nöckler K. Epidemiology, diagnosis, treatment, and control of trichinellosis. Clin Microbiol Rev 2009; 22: 127-145. https://doi.org/10.1128/CMR.00026-08

99. Dupouy-Camet J, Kociecka W, Bruschi F, Bolas-Fernandez F,
Pozio E. Opinion on the diagnosis and treatment of human trichinellosis. Expert Opin Pharmacother 2002; 3: 1117-1130. https://doi.org/10.1517/14656566.3.8.1117

100. Bruschi F, Murrell KD. Chapter 119. Trichinellosis. Part 6. Helminthic infections. In Strickland GT, Hunter GW eds, Hunter's Tropical Medicine and Emerging Infectious Diseases (8th ed.) Philadelphia, USA. Saunders. 2000, pp. 882-884.

101. López-García ML,Torrado S, Torrado S, Martínez AR, Bolás F. Methimazole-mediated enhancement of albendazole oral bioavailability and anthelmintic effects against parenteral stages of Trichinella spiralis in mice: the influence of the dose-regime. Vet Parasitol 1998; 75: 209-219. https://doi.org/10.1016/S0304-4017 (97)00177-5

102. Kalaiselvan R, Mohanta GP, Madhusudan S, Manna PK, Manavalan R. Enhancement of bioavailability and anthelmintic efficacy of albendazole by solid dispersion and cyclodextrin complexation techniques. Pharmazie 2007; 62: 604-607. https://doi.org/10.1691/ph.2007.8.6274

103. Eid RK, Ashour DS, Essa EA, El Maghraby GM, Arafa MF. Chitosan coated nanostructured lipid carriers for enhanced in vivo efficacy of albendazole against Trichinella spiralis. Carbohyd Polym 2020; 232: 115826. https://doi.org/10.1016/j.carbpol.2019.115826

104. Fernando SSE, Denham DA. The effects of mebendazole and fenbendazole on Trichinella spiralis in mice. J Parasitol 1976; 62: 874-876. https://doi.org/10.2307/3279176

105. Sonnet JJ, Theinpont D. The treatment of trichinosis with mebendazole. Int J Clin Lab Med 1977; 32: 297-302. https://doi. org/10.1080/17843286.1977.11717878

106. Levin ML. Treatment of trichinosis with mebendazole. Am J Trop Med Hyg 1983; 32; 980-983. https://doi.org/10.4269/ajtmh. 1983.32.980

107. Pozio E, Sacchini D, Sacchi L, Tamburrini A, Alberici F. Failure of mebendazole in the treatment of humans with Trichinella spiralis infection at the stage of encapsulating larvae. Clin Infect Dis 2001; 32: 638-642. https://doi.org/10.1086/318707

108. Cheetham RF, Markus MB. Drug treatment of experimental Capillaria hepatica infection in mice. Parasitol Res 1991; 77: 517520. https://doi.org/10.1007/BF00928420

109. Choe GY, Lee HS, Seo JK, Chai JY, Lee SH, Eom KS, Chi JG. Hepatic capillariasis: first case report in Korea. Am J Trop Med Hyg 1993; 48: 610-625. https://doi.org/10.4269/ajtmh.1993.48.610

110. Sawamura R, Fernandes MI, Peres LC, Galvão LC, Goldani HA, Jorge SM, de Melo Rocha G, de Souza NM. Hepatic capillariasis in children: report of 3 cases in Brazil. Am J Trop Med Hyg 1999; 61: 642-647. https://doi.org/10.4269/ajtmh.1999.61.642

111. Dubey A, Bagchi A, Sharma D, Dey A, Nandy K, Sharma R. Hepatic capillariasis-drug targets. Infect Disord Drug Targ 2018; 18: 3-10. https://doi.org/10.2174/1871526517666170427124254

112. Cross JH, Basaca-Sevilla V. Albendazole in the treatment of intestinal capillariasis. Southeast Asian J Trop Med Public Health 1987; 18: 507-510.

113. Lee SH, Hong ST, Chai JY, Kim WH, Kim YT, Song IS, Kim SW, Choi BI, Cross JH. A case of intestinal capillariasis in the Re- 
public of Korea. Am J Trop Med Hyg 1993; 48: 542-546. https:// doi.org/10.4269/ajtmh.1993.48.542

114. Hong ST, Kim YT, Choe GY, Min YI, Cho SH, Kim JK, Kook J, Chai JY, Lee SH. Two cases of intestinal capillariasis in Korea. Korean J Parasitol 1994; 32: 43-48. http://dx.doi.org/10.3347/ kjp.1994.32.1.43

115. Bair MJ, Hwang KP, Wang TE, Liou TC, Lin SC, Kao CR, Wang TY, Pang KK. Clinical features of human intestinal capillariasis in Taiwan. World J Gastroenterol 2004; 10: 2391-2393. https:// doi.org/10.3748/wjg.v10.i16.2391

116. Soukhathammavong P, Sayasone S, Harimanana AN, Akkhavong A, Thammasack S, Phoumindr N, Choumlivong K, Choumlivong K, Keoluangkhot V, Phongmany S, Akkhavong K, Hatz C, Strobel M, Odermatt P. Three cases of intestinal capillariasis in Lao People's Democratic Republic. Am J Trop Med Hyg 2008; 79: 735-738. https://doi.org/10.4269/ajtmh.2008. 79.735

117. Rana SS, Bhasin DK, Bhatti HS, Gupta K, Gupta R, Nada R, Nagi B, Sinha SK, Singh K. Human intestinal capillariasis: diagnosis by jejunal fluid analysis obtained at enteroscopy and reversal of subtotal villous atrophy after treatment. Endoscopy 2009; 41 (suppl): 102-103. https://doi.org/10.1055/s-00281119609

118. Sadaow L, Sanpool O, Intapan PM, Sukeepaisarnjaroen W, Prasongdee TK, Maleewong W. A hospital-based study of intestinal capillariasis in Thailand: clinical features, potential clues for diagnosis, and epidemiological characteristics of 85 patients. Am J Trop Med Hyg 2018; 98: 27-31. https://doi.org/10.4269/ajtmh. 17-0465

119. Alcantara AK, Uylangco CV, Cross JH. An obstinate case of intestinal capillariasis. Southeast Asian J Trop Med Public Health 1985; 16: 410-413.

120. Hoghooghi-Rad N, Maraghi S, Narenj-Zadeh A. Capillaria philippinensis infection in Khoozestan province, Iran: case report. Am J Trop Med Hyg 1987; 37: 135-137. https://doi.org/10.4269/ajtmh. 1987.37.135

121. Dronda F, Chaves F, Sanz A, Lopez-Velez R. Human intestinal capillariasis in an area of nonendemicity: case report and review. Clin Infect Dis 1993; 17: 909-912. https://doi.org/10.1093/dinids/ 17.5.909

122. Mansour NS, Anis MH, Mikhail EM. Human intestinal capillariasis in Egypt. Trans R Soc Trop Med Hyg 1990; 84: 114. https:// doi.org/10.1016/0035-9203(90)90398-X

123. Hwang KP, Chen ER. Clinical studies on angiostrongyliasis cantonensis among children in Taiwan. Southeast Asian J Trop Med Public Health 1991; 22 (suppl): 194-199.

124. Wang X, Huang H, Dong Q, Lin Y, Wang Z, Li F, Nawa Y, Yoshimura K. A clinical study of eosinophilic meningoencephalitis caused by angiostrongyliasis. Chin Med J 2002; 115: 13121315.

125. Chotmongkol V, Wongjitrat C, Sawadpanit K, Sawanyawisuth K. Treatment of eosinophilic meningitis with a combination of albendazole and corticosteroid. Southeast Asian J Trop Med
Public Health 2004; 35: 172-174.

126. Wang J, Qi H, Diao Z, Zheng X, Li X, Ma S, Ji A, Yin C. An outbreak of angiostrongyliasis cantonensis in Beijing. J Parasitol 2010; 96: 377-381. https://doi.org/10.1645/GE-2214-1

127. Federspiel F, Skovmand S, Skarphedinsson S. Eosinophilic meningitis due to Angiostrongylus cantonensis in Europe. Int J Infect Dis 2020; 93: 28-39. https://doi.org/10.1016/j.ijid.2020.01.012

128. Tsai HC, Liu YC, Kunin CM, Lee SS, Chen YS, Lin HH, Tsai TH, Lin WR, Huang CK, Yen MY, Yen CM. Eosinophilic meningitits caused by Angiostrongylus cantonensis: report of 17 cases. Am J Med 2001; 111: 109-114. https://doi.org/10.1097/MD.0000000000010975

129. Chotmongkol V, Sawadpanitch K, Sawanyawisuth K, Louhawilai S, Limpawattana P. Treatment of eosinophilic meningitis with a combination of prednisolone and mebendazole. Am J Trop Med Hyg 2006; 74: 1122-1124. https://doi.org/10.4269/ ajtmh.2006.74.1122

130. Leone S, De Marco M, Ghirga P, Nicastri E, Esposito M, Narciso P. Eosinophilic meningitis in a returned traveler from Santo Domingo: case report and review. J Travel Med 2007; 14: 407410. https://doi.org/10.1111/j.1708-8305.2007.00152.x

131. Hermes CC, Benvegnú E, Costa MM, Rodriguez R, Vieira MIB. Abdominal angiostrongyliasis: pathologic findings in Swiss mice infected with different doses of Angiostrongylus costaricensis. J Helminthol 2020; 94: e169. https://doi.org/10.1017/ S0022149X20000516

132. Dekumyoy P, Watthanakulpanich D. Chapter 121. Gnathostomiasis. Part 6. Helminthic Infections. In Ryan ET, Hill DR, Solomon T, Aronson NE, Endy TP eds, Hunter's Tropical Medicine and Emerging Infectious Diseases, 10th ed. Edinburgh, Scotland. Elsevier. 2020, pp 888-890.

133. Kraivichian K, Kulkumthorn M, Yingyourd P, Akarabovorn P, Paireepai CC. Albendazole for the treatment of human gnathostomiasis. Trans R Soc Trop Med Hyg 1992; 86: 418-421. https://doi.org/10.1016/0035-9203(92)90248-B

134. Nontasut P, Bussaratid V, Chullawichit S, Charoensook N, Visetsuk K. Comparison of ivermectin and albendazole treatment for gnathostomiasis. Southeast Asian J Trop Med Public Health 2000; 31: 374377. https://www.tm.mahidol.ac.th/seameo/2000_31_2/29-2490. pdf

135. Nontasut P, Claesson BA, Dekumyoy P, Pakdee W, Chullawichit $\mathrm{S}$. Double-dose ivermectin vs albendazole for the treatment of gnathostomiasis. Southeast Asian J Trop Med Public Health 2005; 36: 650-652.

136. Kraivichian K, Nuchprayoon S, Sitichalernchai P, Chaicumpa W, Yentakam S. Treatment of cutaneous gnathostomiasis with ivermectin. Am J Trop Med Hyg 2004; 71: 623-628. https://doi. org/10.4269/ajtmh.2004.71.623

137. Haddad Junior V, Oliveira ÍF, Bicudo NP, Marques MEA. Gnathostomiasis acquired after consumption of raw freshwater fish in the Amazon region: a report of two cases in brazil. Rev Soc Bras Med Trop 2021; 54: e20200127. https://doi.org/10.1590/0037-86820127-2020

138. Chai JY, Han ET, Shin EH, Park JH, Chu JP, Hirota M, Nakamura- 
Uchiyama F, Nawa Y. An outbreak of gnathostomiasis among Korean emigrants in Myanmar. Am J Trop Med Hyg 2003; 69: 67-73. https://doi.org/10.4269/ajtmh.2003.69.67

139. Vanegas ES, Cendejas RF, Mondragón A. A 41-year-old woman with migratory panniculitis. Am J Trop Med Hyg 2014; 90: 786-787. https://doi.org/10.4269/ajtmh.13-0318

140. Sharma C, Piyaphanee W, Watthanakulpanich D. Case report: clinical features of intermittent migratory swelling caused by gnathostomiasis with complete follow-up. Am J Trop Med Hyg 2017; 97: 1611-1615. https://doi.org/10.4269/ajtmh.17-0239

141. Herman JS, Chiodini PL. Gnathostomiasis, another emerging imported disease. Clin Microbiol Rev 2009; 22: 484-492. https://doi.org/10.1128/CMR.00003-09

142. Raharisoa A, Izri A, Andrianjafy RL, Rajaona RA, Marteau A, Durand R, Akhoundi M. Autochthonous gnathostomiasis in Madagascar. Emerg Infect Dis 2020; 26: 1875-1877. https:// doi.org/10.3201/eid2608.200383

143. Eberhard ML, Busillo C. Human Gongylonema infection in a resident of New York City. Am J Trop Med Hyg 1999; 61: 5152. https://doi.org/10.4269/ajtmh.1999.61.51

144. Wilson ME, Lorente CA, Allen JE, Eberhard ML. Gongylonema infection of the mouth in a resident of Cambridge, Massachusetts. Clin Infect Dis 2001; 32: 1378-1380. https://doi.org/10.1086/319991

145. Ayala MA, Yencha MW. Gongylonema a parasitic nematode of the oral cavity. Arch Otolaryngol Head Neck Surg 2012; 138: 1082-1084. https://doi.org/10.1001/2013.jamaoto.386

146. Waisberg V, Lima WDS, Vasconcelos-Santos DV. Intraocular Gongylonema infection: first case in humans. Ocul Immunol Inflam 2016; 26: 595-597. https://doi.org/10.1080/09273948.20 16.1232739

147. Xiaodan L, Zhensheng W, Ying H, Hongwei L, Jiangqiu J, Peiru $\mathrm{Z}$, Sha S, Zhimin Y. Gongylonema pulchrum infection in the human oral cavity: a case report and literature review. Oral Surg Oral Med Oral Pathol Oral Radiol 2018; 125: e49-e53. https:// doi.org/10.1016/j.oooo.2017.11.019

148. Libertin CR, Reza M, Peterson JH, Lewis J, Hata DJ. Human Gongylonema pulchrum infection: esophageal symptoms and need for prolonged albendazole therapy. Am J Trop Med Hyg 2017; 96: 873-875. https://doi.org/10.4269/ajtmh.16-0852

149. Kudo N, Kubota H, Gotoh H, Ishida H, Ikadai H, Oyamada T. Efficacy of thiabendazole, mebendazole, levamisole and ivermectin against gullet worm, Gongylonema pulchrum: in vitro and in vivo studies. Vet Parasitol 2008; 151: 46-52. https://doi. org/10.1016/j.vetpar.2007.10.005

150. do Vale B, Lopes AP, Fontes MC, Silvestre M, Cardoso L, Coelho AC. Thelaziosis due to Thelazia callipaeda in Europe in the 21st century-a review. Vet Parasitol 2019; 275; 108957. https:// doi.org/10.1016/j.vetpar.2019.108957

151. Calero-Bernal R, Sánchez-Murillo JM, Alarcón-Elbal PM, Sánchez-Moro J, Latrofa MS, Dantas-Torres F, Otranto D. Resolution of canine ocular thelaziosis in avermectin-sensitive Border Collies from Spain. Vet Parasitol 2014; 200: 203-206. https:// doi.org/10.1016/j.vetpar.2013.12.014
152. Sharma M, Das D, Bhattacharjee H, Islam S, Deori N, Bharali G, Tomar S, Bhola P, Deka A. Human ocular thelaziasis caused by gravid Thelazia callipaeda-a unique and rare case report. Ind J Ophthalmol 2019; 67: 282-285. https://doi.org/10.4103/ijo. IJO_1110_18

153. Müllner A, Helfer A, Kotlyar D, Oswald J, Efferth T. Chemistry and pharmacology of neglected helminthic diseases. Curr Med Chem 2011; 18: 767-789. https://doi.org/10.2174/092986711794480096

154. Eberhard ML, Brandt FH, Ruiz-Tiben E, Hightower A. Chemoprophylactic drug trials for treatment of dracunculiasis using the Dracunculus insignis-ferret model. J Helminthol 1990; 64: 79-86. https://doi.org/10.1017/S0022149X00011962

155. Escobedo F, Penagos P, Rodriguez J, Sotelo J. Albendazole therapy for neurocysticercosis. Arch Intern Med 1987; 147: 738741. https://doi.org/10.1001/archinte.1987.00370040120021

156. Sotelo J, Escobedo F, Oenagos P. Albendazole vs praziquantel for therapy for neurocysticercosis. A controlled trial. Arch Neurol 1988; 45: 532-534. https://doi.org/10.1001/archneur.1988.00520290064015

157. Alarcón F, Escalante L, Duefias G, Montalvo M, Román M. Neurocysticercosis. Short course of treatment with albendazole. Arch Neurol 1989: 46: 1231-1236. https://doi.org/10.1001/ archneur.1989.00520470099034

158. Sotelo J, Jung H. Pharmacokinetic optimization of the treatment of neurocysticercosis. Clin Pharmacokinet 1998; 34: 503515. https://doi.org/10.2165/00003088-199834060-00006

159. García HH, Evans CA, Nash TE, Takayanagui OM, White AC Jr, Botero D, Rajshekhar V, Tsang VC, Schantz PM, Allan JC, Flisser A, Correa D, Sarti E, Friedland JS, Martinez SM, Gonzalez AE, Gilman RH, Del Brutto OH. Current consensus guidelines for treatment of neurocysticercosis. Clin Microbiol Rev 2002; 15: 747-756. https://doi.org/10.1128/CMR.15.4.747-756.2002

160. del Brutto $\mathrm{OH}$, Sotelo J. Albendazole therapy for subarachnoid and ventricular cysticercosis-case report. J Neurosurg 1990; 72: 816-817. https://doi.org/10.3171/jns.1990.72.5.0816

161. Arroyo G, Bustos JA, Lescano AG, Gonzales I, Saavedra H, Rodriguez S, Pretell EJ, Bonato PS, Lanchote VL, Takayanagui OM, Horton J, Gonzalez AE, Gilman RH, Garcia HH, Cysticercosis Working Group in Peru. Albendazole sulfoxide plasma levels and efficacy of antiparasitic treatment in patients with parenchymal neurocysticercosis. Clin Infect Dis 2019; 69: 1996 2002. https://doi.org/10.1093/cid/ciz085

162. Schmidt DK, Jordaan HF, Schneider JW, Cilliers J. Cerebral and subcutaneous cysticercosis treated with albendazole. Int J Dermatol 1995; 34: 574-579. https://doi.org/10.1111/j.1365-4362.1995. tb02959.x

163. Surve A, Goel S, Bajaj MS, Pujari A. Extraocular muscle cysticercosis: never skip steroids. BMJ Case Rep 2018; 2018: 1-2. https:// 10.1136/bcr-2017-223356

164. Palomares-Alonso F, Toledo A, Palencia Hernández G, JungCook H, Fleury A. Effect of dexamethasone on albendazole cysticidal activity in experimental cysticercosis by Taenia crassiceps in BALB/c mice: in vivo and in vitro evaluation. Exp Parasitol 2020; 208: 107801. https://doi.org/10.1016/j.exppara.2019.107801 
165. Cook GC. Use of benzimidazole chemotherapy in human helminthiases: indications and efficacy. Parasitol Today 1990; 6: 133-136. https://doi.org/10.1016/0169-4758(90)90232-S

166. Heath DD, Christie MJ, Chevis RAF. The lethal effect of mebendazole on secondary Echinococcus granulosus, cysticerci of Taenia pisiformis and tetrathyridia of Mesocestoides corti. Parasitology 1975; 70: 273-285. https://doi.org/10.1017/S0031182000049738

167. Francisca PA, Javier LF, Guadalupe PH, Fernanda GM, Nelly C, Helgi JC, Iliana GH, Susana RTI. Cysticidal activity of praziquantel-mebendazole combination: in vitro and in vivo studies. Acta Trop 2019; 202: 105238. https://doi.org/10.1016/j.actatropica.2019.105238

168. Hemphill A, Stadelmann B, Rufener R, Spiliotis M, Boubaker G, Müller J, Müller N, Gorgas D, Gottstein B. Treatment of echinococcosis: albendazole and mebendazole-what else? Parasite 2014; 21: 70. https://doi.org/10.1051/parasite/2014073

169. Velasco-Tirado V, Alonso-Sardón M, Lopez-Bernus A, RomeroAlegría Á, Burguillo FJ, Muro A, Carpio-Pérez A, Muñoz Bellido JL, Pardo-Lledias J, Cordero M, Belhassen-García M. Medical treatment of cystic echinococcosis: systematic review and metaanalysis. BMC Infect Dis 2018; 18: 306. https://doi.org/10.1186/ s12879-018-3201-y

170. Saimot AG, Meulemans A, Cremieux AC, Giovanangeli MD, Hay JM, Delaitre B, Coulaud JP. Albendazole as a potential treatment for human hydatidosis. Lancet 1983; 322: 652-656. https://doi.org/10.1016/S0140-6736(83)92533-3

171. Morris DL, Dykes PW, Dickson B, Marriner SE, Bogan JA, Burrows FGO. Albendazole in hydatid disease. Br Med J 1983; 286: 103-104. https://doi.org/10.1136/bmj.286.6359.103-a

172. Todorov T, Vutova K, Mechkov G, Georgiev P, Petkov D, Tonchev Z, Nedelkov G. Chemotherapy of human cystic echinococcosis: comparative efficacy of mebendazole and albendazole. Ann Trop Med Parasitol 1992; 86: 59-66. https://doi.org/ 10.1080/00034983.1992.11812631

173. Horton RJ. Albendazole in treatment of human cystic echinococcosis: 12 years of experience. Acta Trop 1997; 64: 79-93. https://doi.org/10.1016/S0001-706X(96)00640-7

174. Horton J. Albendazole for the treatment of echinococcosis. Fundam Clin Pharmacol 2003; 17: 205-212. https://doi. org/10.1046/j.1472-8206.2003.00171.x

175. Falagas ME, Bliziotis IA. Albendazole for the treatment of human echinococcosis: a review of comparative clinical trials. Am J Med Sci 2007; 334: 171-179. https://doi.org/10.1097/MAJ.0b013e31814252f8

176. Mohamed AE, Yasawy MI, Karawi MAA. Combined albendazole and praziquantel versus albendazole alone in the treatment of hydatid disease. Hepatogastroenterology 1998; 45: 1690-1694.

177. Cobo F, Yarnoz C, Sesma B, Fralle P, Aizcorbe M, Trujillo R, Diaz-de-Liaño A, Ciga MA. Albendazole plus praziquantel versus albendazole alone as a pre-operative treatment in intra-abdominal hydatidosis caused by Echinococcus granulosus. Trop Med Int health 1998; 3: 462-466. https://doi.org/10.1046/j.13653156.1998.00257.x
178. Mueller PR, Dawson SL, Ferrucci JT Jr, Nardi GL. Hepatic echinococcal cyst: successful percutaneous drainage. Radiology 1985; 155: 627-628. https://doi.org/10.1148/radiology.155.3.3890001

179. Khuroo MS, Dar MY, Yattoo GN, Zargar SA, Javaid G, Khan BA, Boda MI. Percutaneous drainage versus albendazole therapy in hepatic hydatidosis: a prospective, randomized study. Gastroenterology 1993; 104: 1452-1459. https://doi.org/10.1016/0016 5085(93)90355-G

180. Khuroo MS, Wani NA, Javaid G, Khan BA, Yattoo GN, Shah AH, Jeelani SG. Percutaneous drainage compared with surgery for hepatic hydatid cysts. N Engl J Med 1997; 337: 881-887. https://doi.org/10.1056/NEJM199709253371303

181. Smego RA Jr, Bhatti S, Khaliq AA, Beg MA. Percutaneous aspiration-injection-reaspiration drainage plus albendazole or mebendazole for hepatic cystic echinococcosis: a meta-analysis. Clin Infect Dis 2003; 37: 1073-1083. https://doi.org/10.1086/378275

182. Örmeci N, Kalkan Ç, Karakaya F, Erden A, Köse KS, Tüzün AE, Deda X. Percutaneous treatment with the Örmeci technique of cystic echinococcosis: experience of single center. Gastroenterol Hepatol Open Access 2020; 11: 223-230. https://doi.org/10.15406/ ghoa.2020.11.00443

183. Heath DD, Chevis RAF. Mebendazole and hydatid cysts. Lancet 1974; 304: 218-219. https://doi.org/10.1016/S0140-6736(74) 91517-7

184. Bekhti A, Schaaps JP, Capron M, Dessaint JP, Santoro F, Capron A. Treatment of hepatic hydatid disease with mebendazole: preliminary results in four cases. Br Med J 1977; 2: 1047-1051. https://doi.org/10.1136/bmj.2.6094.1047

185. Verheyen A. Echinococcus granulosus: the influence of mebendazole therapy on the ultrastructural morphology of the germinal layer of hydatid cysts in humans and mice. Z Parazitenkd 1982; 67: 55-65. https://doi.org/10.1007/BF00929514

186. Göçmen A, Toppare MF, Kiper N. Treatment of hydatid disease in childhood with mebendazole. Eur Respir J 1993; 6: 253257. https://erj.ersjournals.com/content/6/2/253

187. Salto E, Juárez E, Roiz MP, Abad J. Combined chemotherapy (mebendazole plus praziquantel) in patients with hydatidosis. Enferm Infecc Microbiol Clin 1991; 9: 527-529 (in Spanish). https://europepmc.org/article/med/1822703

188. Vutova K, Mechkov G, Vachkov P, Petkov R, Georgiev P, Handjiev S, Ivanovh A, Todorov T. Effect of mebendazole on human cystic echinococcosis: the role of dosage and treatment duration. Ann Trop Med Parasitol 1999; 93: 357-365. https://doi.or g/10.1080/00034983.1999.11813432

189. Ammann RW, Fleiner-Hoffmann A, Grimm F, Eckert J. Long-term mebendazole therapy may be parasitocidal in alveolar echinococcosis. J Hepatol 1998; 29: 994-998. https://doi.org/10.1016/S01688278(98)80129-3

190. Addiss D, Gamble CL, Garner P, Gelband H, Ejere HOD, Critchley JA. Albendazole for lymphatic filariasis. Cochrane Datab Syst Rev 2005; 4: CD003753. https://doi.org/10.1002/14651858. CD003753.pub3

191. Kimura E, Penaia L, Spears GFS. The efficacy of annual single- 
dose treatment with diethylcarbamazine citrate against diurnally subperiodic bancroftian filariasis in Samoa. Bull World Health Organ 1985; 63: 1097-1106.

192. Ottesen EA, Ismail MM, Horton J. The role of albendazole in programmes to eliminate lymphatic filariasis. Parasitol Today 1999; 15: 382-386. https://doi.org/10.1016/S0169-4758(99)01486-6

193. Moulia-Pelat JP, Glaziou P, Weil GJ, Nguyen LN, Gaxotte P, Nicolas L. Combination ivermectin plus diethylcarbamazine, a new effective tool for control lymphatic filariasis. Trop Med Parasitol 1995; 46: 9-12. https://europepmc.org/article/med/7631132

194. Jayakody RL, De Silva CSS, Weerasinghe WMT. Treatment of bancroftian filariasis with albendazole: evaluation of efficacy and adverse reactions. Trop Biomed 1993; 10: 19-24.

195. Addiss DA, Beach MJ, Streit TG, Lutwick S, LeConte FH, Lafontant JG, Hightower AW, Lammie PJ. Randomised placebo-controlled comparison of ivermectin and albendazole and in combination for Wuchereria bancrofti microfilaraemia in Haitian children. Lancet 1997; 350: 480-484. https://doi.org/10.1016/ S0140-6736(97)02231-9

196. Ismail MM, Jayakody RL, Weil GJ, Nirmalan N, Jayasinghe KS, Abeyewickrema W, Rezvi Sheriff MH, Rajaratnam HN, Amarasekera N, de Silva DC, Michalski ML, Dissanaike AS. Efficacy of single dose combinations of albendazole, ivermectin and diethylcarbamazine for the treatment of bancroftian filariasis. Trans $\mathrm{R}$ Soc Trop Med Hyg 1998; 92: 94-97. https://doi.org/10.1016/S00359203(98)90972-5

197. Horton J. The development of albendazole for lymphatic filariasis. Ann Trop Med Parasitol 2009; 103(suppl): 33-40. https:// doi.org/10.1179/000349809X12502035776595

198. Pion SDS, Chesnais CB, Awaca-Uvon NP, Vlaminck J, Abdou A, Kunyu-Shako B, Kuyangisa Simuna G, Tambwe JP, Weil GJ, Boussinesq $M$. The impact of four years of semiannual treatments with albendazole alone on lymphatic filariasis and soiltransmitted helminth infections: a community-based study in the Democratic Republic of Congo. PLoS Negl Trop Dis 2020; 14: e0008322. https://doi.org/10.1371/journal.pntd.0008322

199. Ottesen EA, Duke BO, Karam M, Behbehani K. Strategies and tools for the control/elimination of lymphatic filariasis. Bull World Health Organ 1997; 75: 491-503.

200. Shenoy RK, Dalia S, John A, Suma TK, Kumaraswami V. Treatment of the microfilaraemia of asymptomatic brugian filariasis with single doses of ivermectin, diethylcarbamazine or albendazole, in various combinations. Ann Trop Med Parasitol 1999; 93: 643-651. https://doi.org/10.1080/00034983.1999.11 813467

201. Fischer P, Djuardi Y, Ismid IS, Rückert P, Bradley M, Supali T. Long-lasting reduction of Brugia timori microfilariae following a single dose of diethylcarbamazine combined with albendazole. Trans R Soc Trop Med Hyg 2003; 97: 446-448. https://doi. org/10.1016/S0035-9203(03)90086-1

202. Gyapong JO, Kumaraswami V, Biswas G, Ottesen EA. Treatment strategies underpinning the global programme to eliminate lymphatic filariasis. Expert Opin Pharmacother 2005; 6:
179-200. https://doi.org/10.1517/14656566.6.2.179

203. Tisch DJ, Michael E, Kazura JW. Mass chemotherapy options to control lymphatic filariasis: a systematic review. Lancet Infect Dis 2005; 5: 514-523. https://doi.org/10.1016/S1473-3099 (05)70192-4

204. Critchley J, Addiss D, Ejere H, Gamble C, Garner P, Helband H. Albendazole for the control and elimination of lymphatic filariasis: systematic review. Trop Med Int Health 2005; 10: 818825. https://doi.org/10.1111/j.1365-3156.2005.01458.x

205. Macfarlane CL, Budhahoki SS, Johnson S, Richardson M, Garner P. Albendazole along or in combination with microfilaricidal drugs for lymphatic filariasis (Review). Cochrane Datab Syst Rev 2019; 1: CD003753. https://doi.org/10.1002/14651858.CD003753.pib4

206. Kar SK, Dwibedi B, Das BK, Agrawala BK, Ramachandran CP, Horton J. Lymphatic pathology in asymptomatic and symptomatic children with Wuchereria bancrofti infection in children from Odisha, India and its reversal with DEC and albendazole treatment. PLoS Negl Trop Dis 2017; 11: e0005631. https://doi. org/10.1371/journal.pntd.0005631

207. Edi C, Bjerum CM, Ouattara AF, Chhonker YS, Penali LK, Méité A, Koudou BG, Weil GJ, King CL, Murry DJ. Pharmacokinetics, safety, and efficacy of a single co-administered dose of diethylcarbamazine, albendazole and ivermectin in adults with and without Wuchereria bancrofti infection in Côte d'Ivoire. PLoS Negl Trop Dis 2019; 13: e0007325. https://doi.org/10.1371/ journal.pntd.0007325

208. Jambulingam P, Kuttiatt VS, Krishnamoorthy K, Subramanian S, Srividya A, Raju HKK, Rahi M, Somani RK, Suryaprakash MK, Dwivedi GP, Weil GJ. An open label, block randomized, community study of the safety and efficacy of co-administered ivermectin, diethylcarbamazine plus albendazole vs. diethylcarbamazine plus albendazole for lymphatic filariasis in India. PLoS Negl Trop Dis 2021; 15: e0009069. https://doi.org/10.1371/journal.pntd.0009069

209. Turner JD, Mad S, Debrah AY, Muehlfeld J, Pfarr K, McGarry HF, Adjei O, Taylor MJ, Hoerauf A. A randomized, doubleblind clinical trial of a 3-week course of doxycycline plus albendazole and ivermectin for the treatment of Wuchereria bancrofti infection. Clin Infect Dis 2006; 42: 1081-1089. https://doi. org/10.1086/501351

210. Sarma RVSN, Vallishayee RS, Rao RSN, Prabhakar R, Tripathy SP. Use of mebendazole in combination with DEC in bancroftian filariasis. Indian J Med Res 1988; 87: 579-583. https://eprints. nirt.res.in/242/

211. Awadzi K, Edwards G, Duke BOL, Opoku NO, Attah SK, Addy ET, Ardrey AE, Quartey BT. The co-administration of ivermectin and albendazole-safety, pharmacokinetics and efficacy against Onchocerca volvulus. Ann Trop Med Parasitol 2003; 97: 165178. https://doi.org/10.1179/000349803235001697

212. Awadzi K, Hero M, Opoku O, Büttner DW, Gilles HM. The chemotherapy of onchocerciasis. XV. Studies with albendazole. Trop Med Parasitol 1991; 42: 356-360. https://europepmc.org/ 
article/med/1796233

213. Cline BL, Hernandez JL, Mather FJ, Bartholomew R, Maza SN, Rodulfo S, Welborn CA, Eberhard ML, Convit J. Albendazole in the treatment of onchocerciasis: double-blind clinical trial in Venezuela. Am J Trop Med Hyg 1992; 47: 512-520. https://doi. org/10.4269/ajtmh.1992.47.512

214. Awadzi K, Addy ET, Opoku NO, Plenge-Bönig A, Büttner DW. The chemotherapy of onchocerciasis. XX. Ivermectin in combination with albendazole. Trop Med Parasitol 1995; 46: 213220. https://europepmc.org/article/med/8826100

215. Batsa Debrah L, Klarmann-Schulz U, Osei-Mensah J, Dubben B, Fischer K, Mubarik Y, Ayisi-Boateng NK, Ricchiuto A, Fimmers R, Konadu P, Nadal J, Gruetzmacher B, Weil G, Kazura JW, King CL, Debrah AY, Hoerauf A. Comparison of repeated doses of ivermectin versus ivermectin plus albendazole for the treatment of onchocerciasis: a randomized, open-label, clinical trial. Clin Infect Dis 2020; 71: 933-943. https://doi.org/10.1093/ cid/ciz889

216. Taylor MJ, Hoerauf A, Bockarie M. Lymphatic filariasis and onchocerciasis. Lancet 2010; 376: 1175-1185. https://doi.org/10.1016/ S0140-6736(10)60586-7

217. Klarmann-Schulz U, Specht S, Debrah AY, Batsa L, AyisiBoateng NK, Osei-Mensah J, Mubarik Y, Konadu P, Ricchiuto A, Fimmers R, Arriens S, Dubben B, Ford L, Taylor M, Hoerauf A. Comparison of doxycycline, minocycline, doxycycline plus albendazole and albendazole alone in their efficacy against onchocerciasis in a randomized, open-label, pilot trial. PLoS Negl Trop Dis 2017; 11: e0005156. https://doi.org/10.1371/journal. pntd.0005156

218. Fischer PU, King CL, Jacobson JA, Weil GJ. Potential value of triple drug therapy with ivermectin, diethylcarbamazine, and albendazole (IDA) to accelerate elimination of lymphatic filariasis and onchocerciasis in Africa. PLoS Negl Trop Dis 2017; 11: e0005163. https://doi.org/10.1371/journal.pntd.0005163

219. Duke BOL. Mebendazole-ineffective against Onchocerca volvulus. Trans R Soc Trop Med Hyg 1974; 68: 172. https://doi.org/ 10.1016/0035-9203(74)90199-0

220. Maertens K, Wéry M. Effect of mebendazole and levamisole on Onchocerca volvulus and Dipetalonema perstans. Trans R Soc Trop Med Hyg 1975; 69: 359-360. https://doi.org/10.1016/0035-9203 (75)90134-0

221. Taylor HR, Awadzi K, George T, Schulz-Key H, Murphy RP. Fluorescein angiographic studies of mebendazole treatment for onchocerciasis. Trop Med Parasitol 1985; 36: 7-11. https://europepmc.org/article/med/4001769

222. Rivas-Alcalá AR, Greene BM, Taylor HR, Domíguez-Vázquez A, Ruvalcaba-Macías AM, Lugo-Pfeiffer C, Mackenzie CD, Beltrán F. Chemotherapy of onchocerciasis: a controlled comparison of mebendazole, levamisole, and diethylcarbamazine. Lancet 1981; 318: 485-490. https://doi.org/10.1016/S0140-6736(81)90880-1

223. Awadzi K, Schulz-Key H, Howells RE, Haddock DRW, Gilles HM. The chemotherapy of onchocerciasis. VIII. Levamisole and its combination with the benzimidazoles. Ann Trop Med
Parasitol 1982; 76: 459-473. https://doi.org/10.1080/0003498 3.1982.11687567

224. Awadzi K. Research notes from the Onchocerciasis Chemotherapy Research Centre, Ghana. Ann Trop Med Parasitol 1997; 91: 703-711. https://doi.org/10.1080/00034983.1997.11813193

225. Awadzi K, Edwards G, Opoku NO, Ardrey AE, Favager S, Addy ET, Attah SK, Yamuah LK, Quartey BT. The safety, tolerability and pharmacokinetics of levamisole alone, levamisole plus ivermectin, and levamisole plus albendazole, and their efficacy against Onchocerca volvulus. Ann Trop Med Parasitol 2004; 98: 595-614. https://doi.org/10.1079/000349804225021370

226. Klion AD, Massougbodji A, Horton J, Ekoué S, Lanmasso T, Ahouissou NL, Nutman TB. Albendazole in human loiasis: results of a double-blind, placebo-controlled trial. J Infect Dis 1993; 168: 202-206. https://doi.org/10.1093/infdis/168.1.202

227. Klion AD, Horton J, Nutman TB. Albendazole therapy for loiasis refractory to diethylcarbamazine treatment. Clin Infect Dis 1999; 29: 680-682. https://doi.org/10.1086/598654

228. Arrey-Agbor DB, Nana-Djeunga HC, Mogoung-Wafo AE, Mafo M, Danwe C, Kamgno J. Case report: probable case of spontaneous encephalopathy due to loiasis and dramatic reduction of Loa loa microfilaraemia with prolonged repeated courses of albendazole. Am J Trop Med Hyg 2018; 99: 112-115. https:// doi.org/10.4269/ajtmh.17-0664

229. Gobbi F, Buonfrate D, Tamarozzi F, Degani M, Angheben A, Bisoffi Z. Efficacy of high-dose albendazole with ivermectin for treating imported loiasis, Italy. Emerg Infect Dis 2019; 25: 1574-1576. https://doi.org/10.3201/eid2508.190011

230. Tabi TE, Befidi-Mengue R, Nutman TB, Horton J, Folefack A, Pensia E, Fualem R, Fogako J, Gwanmesia P, Quakyi I, Leke R. Human loiasis in a Cameroonian village: a double-blind, placebo-controlled, crossover clinical trial of a three-day albendazole regimen. Am J Trop Med Hyg 2004; 71: 211-215. https:// doi.org/10.4269/ajtmh.2004.71.211

231. Tsague-Dongmo L, Kamgno J, Pion SDS, Moyou-Somo R, Boussinesq M. Effects of a 3-day regimen of albendazole ( $800 \mathrm{mg}$ daily) on Loa loa microfilaraemia. Ann Trop Med Parasitol 2002; 96: 707-715. https://doi.org/10.1179/000349802125001933

232. Richard-Lenoble D, Komblia M, Burnier I, Maganga ML. Filariasis in Gabon: treatment with mebendazole of filariasis due to Mansonella perstans and Loa loa. Bull Soc Pathol Rxot Filial 1985; 78: 485-491 (in French). https://europepmc.org/article/med/3865739

233. Burchard GD, Kern P. Failure of high dose mebendazole as a microfilaricide in patients with loiasis. Trans R Soc Trop Med Hyg 1987; 81: 420. https://doi.org/10.1016/0035-9203(87)90156-8

234. Van Hoegaerden M, Ivanoff B, Flocard F, Salle A, Chabaud B. The use of mebendazole in the treatment of filariasis due to Loa loa and Mansonella perstans. Ann Trop Med Parasitol 1987; 81: 275282. https://doi.org/10.1080/00034983.1987.11812120

235. Kamgno J, Roussinesq M. Effect of a single dose (600 mg) of albendazole on Loa loa microfilaraemia. Parasite 2002; 9: 5963. https://doi.org/10.1051/parasite/200209159

236. Pion S, Chesnais C. Loiasis. In Marcondes CB ed, Arthropod 
Borne Diseases. Springer, Switzerland. 2017, pp 427-444. https:// doi.org/10.1007/978-3-319-13884-8_27

237. Ta-Tang TH, Crainey JL, Post RJ, Lutz SLB, Rubio JM. Mansonellosis: current perspectives. Res Rep Trop Med 2018; 9: 9-24. https://doi.org/10.2147/RRTM.S125750

238. Puente S, Lago M, Subirats M, Sanz-Esteban I, Arsuaga M, Vicente B, Alonso-Sardon M, Behlhassen-Garcia M, Muro A. Imported Mansonella perstans infection in Spain. Infect Dis Poverty 2020; 9: 105. https://doi.org/10.1186/s40249-020-00729-9

239. Van den Enden E, Van Gompel A, Vervoort T, Van der Stuyft P, Van den Ende J. Mansonella perstans filariasis: failure of albendazole treatment. Ann Soc Belge Med Trop 1992; 72: 215-218. http:// dspace.itg.be/bitstream/handle/10390/4511/1992asbm0215. pdf?sequence $=1$

240. Lipani F, Caramello P, Biglino A, Sacchi C. Albendazole for the treatment of Mansonella perstans filariasis. Trans R Soc Trop Med Hyg 1997; 91: 221. https://doi.org/10.1016/S0035-9203(97)90232-7

241. Duong TH, Kombila M, Ferrer A, Nguiri C, Richard-Lenoble D. Decrease in Mansonella perstans microfilaraemia after albendazole treatment. Trans R Soc Trop Med Hyg 1998; 92: 459. https:// doi.org/10.1016/S0035-9203(98)91093-8

242. Asio SM, Simonsen PE, Onapa AW. Mansonella perstans: safety and efficacy of ivermectin alone, albendazole alone and the two drugs in combination. Ann Trop Med Parasitol 2009; 103: 31-37. https://doi.org/10.1179/136485909X384929

243. Asgeirsson H, Harling A, Botero-Kleiven S. Successful treatment of 2 imported cases of Mansonella perstans infection. PLoS Negl Trop Dis 2017; 11: e0005452. https://doi.org/10.1371/journal. pntd.005452

244. Debrah LB, Phillips RO, Pfarr K, Klarmann-Schulz U, Opoku VS, Nausch N, Owusu W, Mubarik Y, Sander AL, Lämmer C, Ritter M, Layland LE, Jacobsen M, Debrah AY, Hoerauf A. The efficacy of doxycycline treatment on Mansonella perstans infection: an open-label, randomized trial in Ghana. Am H Trop Med Hyg 2019; 101: 84-92. https://doi.org/10.4269/ajtmh.18-0491

245. Wahlgren M. The successful treatment of Dipetalonema perstans filariasis with mebendazole. Ann Trop Med Parasitol 1982; 76: 557-559. https://doi.org/10.1080/00034983.1982.11687580

246. Wahlgren M, Frolov I. Treatment of Dipetalonema perstans infections with mebendazole. Trans R Soc Trop Med Hyg 1983; 77: 422. https://doi.org/10.1016/0035-9203(83)90179-7

247. Bregani ER, Rovellini A, Mbaidoum N, Magnini MG. Comparison of different anthelmintic drug regimens against Mansonella perstans filariasis. Trans R Soc Trop Med Hyg 2006; 100: 458463. https://doi.org/10.1016/j.trstmh.2005.07.009

248. Simón F, Siles-Lucas M, Morchón R, González-Miguel J, Mellado I, Carretán E, Montoya-Alonso JA. Human and animal dirofilariasis: the emergence of a zoonotic mosaic. Clin Microbiol Rev 2012; 25: 507-544. https://doi.org/10.1128/CMR.00012-12

249. GheorghiŢă MI, ForŢofoiu MC, Dumitrescu CI, Dumitrescu D, Camen A, Mărgăritescu C. Intramuscular human Dirofilaria repens infection of the temporal region-case report and review of literature. Rom J Morphol Embryol 2017; 58: 585-592.
250. Ermakova L, Nagorny S, Pschenichnaya N, Ambalov Y. Clinical and laboratory features of human dirofilariasis in Russia. IDCases 2017; 9: 112-115. https://doi.org/10.1016/j.idcr.2017.07.006

251. Moskvina TV, Ermolenko AV. Dirofilariasis in Russian Federation: a big problem with large distribution. Russ Open Med J 2018; 7: e0102. https:/doi.org/10.15275/rusomj.2018.0102

252. Keiser J, Engels D, Buscher G, Utzinger J. Triclabendazole for the treatment of fascioliasis and paragonimiasis. Expert Opin Investig Drugs 2005; 14: 1513-1526. https://doi.org/10.1517/13543784.14.12.1513

253. Mas-Coma S, Velero MA, Bargues MD. Fascioliasis. Adv Exp Med Biol 2019; 1154: 71-103. https://doi.org/10.1007/978-3 030-18616-6_4

254. Ronald NC, Crag TM, Bell RR. A controlled evaluation of albendazole against natural infections with Fasciola hepatica and Fascioloides magna in cattle. Am J Vet Res 1979; 40: 1299-1300.

255. Fetterer R, Rew RS, Knight R. Comparative efficacy of albendazole against Fasciola hepatica in sheep and calves: relationship to serum drug metabolite levels. Vet Parasitol 1982; 11: 309316. https://doi.org/10.1016/0304-4017(82)90099-1

256. Laird PP, Boray JC. Human fascioliasis successfully treated with triclabendazole. Aust N Z J Med 1992; 22: 45-47. https://doi. org/10.1111/j.1445-5994.1992.tb01708.x

257. Apt W, Aguilera X, Vega F, Miranda C, Zulantay I, Perez C, Gabor M, Apt P. Treatment of human chronic fascioliasis with triclabendazole: drug efficacy and serologic response. Am J Trop Med Hyg 1995; 52: 532-535. https://doi.org/10.4269/ajtmh.1995.52.532

258. Zali AH, Ghaziani T, Shahraz S, Hekmatdoost A, Radmehr A. Liver, spleen, pancreas and kidney involvement by human fascioliasis: imaging findings. BMC Gastroenterol 2004; 4: 15 . https://doi.org/10.1186/1471-230X-4-15

259. Saba R, Korkmaz M, Inan D, Mamikoğlu L, Turhan O, Günseren F, Cevikol C, Kabaalioğlu A. Human fascioliasis. Human fascioliasis. Clin Microbiol Infect 2004; 10: 385-387. https://doi.org/10.1111/j.1469-0691.2004.00820.x

260. Robinson MW, Lawson J, Trudgett A, Hoey EM, Fairweather I. The comparative metabolism of triclabendazole sulphoxide by triclabendazole-susceptible and triclabendazole-resistant Fasciola hepatica. Parasitol Res 2004; 92: 205-210. https://doi.org/10.1007/ s00436-003-1003-6

261. Arauco R, Zetola NM, Calderon F, Seas C. Human fascioliasis: a case of hyperinfection and an update for clinicians. Foodborne Pathog Dis 2007; 4: 305-312. https://doi.org/10.1089/fpg.2007.0001

262. Liu YH, Wang XG, Gao P, Qian MX. Experimental and clinical trial of albendazole in the treatment of clonorchiasis sinensis. Chin Med J 1991; 104: 27-31. https://europepmc.org/article/med/1879192

263. Jaroonvesma N, Charoenlarp K, Cross JH. Treatment of Opisthorchis viverrini with mebendazole. Southeast Asian J Trop Med Public Health 1981; 12: 595-597. https://europepmc.org/ article/med/7344109

264. Pungpark S, Radomyos P, Radomyos B, Bunnag D. Albendazole treatment of minute intestinal fluke infections and opisthorchiasis. Parasitol Int 1998; 47 (suppl): 241. https://doi.org/10.1016/ S1383-5769(98)80658-2 
265. Cross JH, Basaca-Sevilla V. Studies on Echinostoma ilocanum in the Philippines. Southeast Asian J Trop Med Public Health 1986; 17: 23-27. https://europepmc.org/article/med/3090713

266. Edlind TD, Hang TL, Chakraborty PR. Activity of the anthelmintic benzimidazoles against Giardia lamblia in vitro. J Infect Dis 1990; 162: 1408-1411. https://doi.org/10.1093/infdis/162.6.1408

267. Meloni BP, Thompson RCA, Reynoldson JA, Seville P. Albendazole: a more effective antigiardial agent in vitro than metronidazole or tinidazole. Trans R Soc Trop Med Hyg 1990; 84: 375379. https://doi.org/10.1016/0035-9203(90)90324-8

268. Reynoldson JA, Thompson RCA, Meloni BP. In vivo efficacy of albendazole against Giardia duodenalis in mice. Parasitol Res 1991; 77: 325-328. https://doi.org/10.1007/BF00930909

269. Barr SC, Bowman DD, Heller RL, Erb HN. Efficacy of albendazole against giardiasis in dogs. Am J Vet Res 1993; 54: 926-928. https://europepmc.org/article/med/8323064

270. Oxberry ME, Thompson RCA, Reynoldson JA. Evaluation of the effects of albendazole and metronidazole on the ultrastructure of Giardia duodenalis, Trichomonas vaginalis and Spironucleus muris using transmission electron microscopy. Int J Parasitol 1994; 24: 695-703. https://doi.org/10.1016/0020-7519(94)90123-6

271. Cheng-i W. Parasitic diarrhoeas in China. Parasitol Today 1988; 4: 284-287. https://doi.org/10.1016/0169-4758(88)90020-8

272. Hall A, Nahar Q. Albendazole as a treatment for infection with Giardia duodenalis in children in Bangladesh. Trans R Soc Trop Med Hyg 1993; 87: 84-86. https://doi.org/10.1016/0035-9203(93)90435-S

273. Escobedo AA, Hanevik K, Almirall P, Cimerman S, Alfonso M. Management of chronic Giardia infection. Expert Rev Anti Infect Ther 2014; 12: 1143-1157. https://doi.org/10.1586/147872 10.2014.942283

274. Cacopardo B, Patamia I, Bonaccorso V, Paola O, Bonforte S, Brancati G. Synergic effect of albendazole plus metronidazole association in the treatment of metronidazole-resistant giardiasis. Clin Ther 1995; 146: $761-767$ (in Italian). https://europepmc. org/article/med/8681495

275. Mørch K, Hanevik K, Robertson LJ, Strand EA, Langeland N. Treatment-ladder and genetic characterization of parasites in refractory giardiasis after an outbreak in Norway. J Infect 2008; 56: 268-273. https://doi.org/10.1016/j.jinf.2008.01.013

276. Escobedo AA, Almirall P, Chirino E, Pacheco F, Duque A, Avila I. Treatment of refractory paediatric giardiasis using secnidazole plus albendazole: a case series. Infect Med 2018; 26: 379-384. https://infezmed.it/media/journal/Vol_26_4_2018_14.pdf

277. Argüello-García R, Leitsch D, Skinner-Adams T, Ortega-Pierres MG. Drug resistance in Giardia: mechanisms and alternative treatments for giardiasis. Adv Parasitol 2020; 107: 201-282. https://doi.org/10.1016/bs.apar.2019.11.003

278. Hutchison JG, Johnston NM, Plevey MV, Thankhiew I. Aidney C. Clinical trial of mebendazole, a broad-spectrum anthelminthic. $\mathrm{Br}$ Med J 1975; 2: 309-310. https://doi.org/10.1136/bmj.2.5966.309

279. Al-Waili NS, Al-Waili BH, Saloom KY. Therapeutic use of mebendazole in giardial infections. Trans R Soc Trop Med Hyg 1988; 82: 438. https://doi.org/10.1016/0035-9203(88)90156-3
280. Gascon J, Corachán M. Mebendazole in giardial infections: a reply. Trans R Soc Trop Med Hyg 1990; 84: 754. https://doi.org/ 10.1016/0035-9203(90)90180-M

281. Al-Waili NS, Hasan NU. Mebendazole in giardial infection: a comparative study with metronidazole. J Infect Dis 1992; 165: 1170-1171. https://doi.org/10.1093/infdis/165.6.1170

282. Katiyar SK, Gordon VR, McLaughlin GL, Edlind TD. Antiprotozoal activities of benzimidazoles and correlations with $\beta$-tubulin sequence. Antimicrob Agents Chemother 1994; 38: 2086-2090. https://doi.org/10.1128/AAC.38.9.2086

283. Goodhew EB, Secor EV. Drug library screening against metronidazole-sensitive and metronidazole-resistant Trichomonas vaginalis isolates. Sex Transm Infect 2013; 89: 479-484. https:// doi.org/10.1136/sextrans-2013-051032

284. Juliano C, Martinotti MG, Cappuccinelli P. "In vitro" effect of microtubule inhibitors on Trichomonas vaginalis. Microbiologica 1985; 8: 31-42. https://europepmc.org/article/med/3871893

285. Cañete R, Escobedo AA, Almirall P, González ME, Brito K, Cimerman S. Mebendazole in parasitic infections other than those caused by soil-transmitted helminths. Trans R Soc Trop Med Hyg 2009; 103: 437-442. https:/doi/org/10.1016/j.trstmh.2008.11.029

286. Pattman RS, Sprott MS, Kearns AM, Earnshaw M. Failure of mebendazole to cure trichomonal vaginitis resistant to metronidazole: case reports. Genitourin Med 1989; 65: 274-275. http:// dx.doi.org/10.1136/sti.65.4.274

287. McDonald LM, Armson A, Thompson RCA, Reynoldson JA. Characterisation of benzimidazole binding with recombinant tubulin from Giardia duodenalis, Encephalitozoon intestinalis, and Cryptosporidium parvum. Mol Biochem parasitol 2004; 138: 8996. https://doi.org/10.1016/j.molbiopara.2004.08.001

288. Fayer R, Fetterer R. Activity of benzimidazoles against cryptosporidiosis in neonatal BALB/c mice. J Parasitol 1995; 81: 794795. https://doi.org/10.2307/3283980

289. Weiss LM. Chapter 109. Microsporidiosis. In Ryan ET, Hill DR, Solomon T, Aronson NE, Endy TP eds, Hunter's Tropical Medicine and Emerging Infectious Diseases, 10th ed. Edinburgh, Scotland. Elsevier. 2020, pp 825-831. https://doi.org/10.1016/ B978-0-323-55512-8.00109-5

290. Blanshard C, Ellis DS, Tovey DG, Dowell S, Gazzard BG. Treatment of intestinal microsporidiosis with albendazole in patients with AIDS. AIDS 1992; 6: 311-313. https://doi.org/10.1097/00002030199203000-00009

291. Nacey CJ, Clarke AM, Fraser P, Metcalfe T, Bonsor G, Curry A. Chronic microsporidian infection of the nasal mucosae, sinuses and conjunctivae in HIV disease. Genitourin Med 1992; 68 179-181. http://doi.org/10.1136/sti.68.3.179

292. Deplazes P, Mathis A, Baumgartner R, Tanner I, Weber R. Immunologic and molecular characteristics of Encephalitozoon-like microsporidia isolated from humans and rabbits indicate that Encephalitozoon cuniculi is a zoonotic parasite. Clin Infect Dis 1996; 22: 557-559. https://doi.org/10.1093/dinids/22.3.557

293. Hocevar SN, Paddock CD, Spak CW, Rosenblatt R, Diaz-Luna H, Castillo I, Luna S, Friedman GC, Antony S, Stoddard RA, 
Tiller RV, Peterson T, Blau DM, Sriam RR, da Silva A, de Almeida M, Benedict T, Goldsmith CS, Zaki SR, Visvesvara GS, Kuehnert MJ. Microsporidiosis acquired through solid organ transplantation: a public health investigation. Ann Intern Med 2014; 160: 213-220. https://doi.org/10.7326/M13-2226

294. Dore GJ, Marriott DJ, Hing MC, Harkness JL, Field AS. Disseminated microsporidiosis due to Septata intestinalis in nine patients infected with the human immunodeficiency virus: response to therapy with albendazole. Clin Infect Dis 1995; 21: 70-76. https://doi.org/10.1093/clinids/21.1.70

295. Dacha S, Pham D, Cai Q. Microsporidiosis: an unusual endoscopic finding. Clin Gastroenterol Hepatol 2014; 12: 37-38. https://doi.org/10.1016/j.cgh.2013.08.030

296. Molina JM, Chastang C, Goguel J, Michiels JF, Sarfati C, Desportes-Livage I, Horton J, Derouin F, Modaï J. Albendazole for treatment and prophylaxis of microsporidiosis due to Encephalitozoon intestinalis in patients with AIDS: a randomized double-blind controlled trial. J Infect Dis 1998; 177: 1373-1377. https://doi. org/10.1086/515268

297. Leder K, Ryan N, Spelman D, Crowe SM. Microsporidial disease in HIV-infected patients: a report of 42 patients and review of the literature. Scand J Infect Dis 1998; 30: 331-338. https:// doi.org/10.1080/00365549850160594

298. Tremoulet AH, Avila-Aguero ML, París MM, Canas-Coto A, Ulloa-Gutierrez R, Faingezicht I. Albendazole therapy for Microsporidium diarrhea in immunocompetent Coasta Rican children. Ped Infect Dis J 2004; 23: 915-918. https://doi.org/10.1097/01. inf.0000141724.06556.f9

299. Molina JM, Sarfati C, Beauvais B, Lémann M, Lesourd A, Ferchal F, Casin I, Lagrange P, Modigliani R, Derouin F, Modal J. Intestinal microsporidiosis in human immunodeficiency virusinfected patients with chronic unexplained diarrhea: prevalence and clinical and biological features. J Infect Dis 1993; 167: 217-221. https://doi.org/10.1093/infdis/167.1.217

300. Dieterich DT, Lew EA, Kotler DP, Poles MA, Orenstein JM. Treatment with albendazole for intestinal disease due to Enterocytozoon bieneusi in patients with AIDS. J Infect Dis 1994; 169: 178-183. https://doi.org/10.1093/infdis/169.1.178

301. Wichro E, Hoelzi D, Krause R, Bertha G, Reinthaler F, Wenisch C. Microsporidiosis in travel-associated chronic diarrhea in immune-competent patients. Am J Trop Med Hyg 2005; 73: 285287. https://doi.org/10.4269/ajtmh.2005.73.285

302. Galván AL, Sánchez AMM, Pérez Valentín MA, Henriques-Gil N, Izquierdo F, Fenoy S, del Aguila C. First cases of microsporidiosis in transplant recipients in Spain and review of the literature. J Clin Microbiol 2011; 49: 1301-1306. https://doi.org/10.1128/ JCM.01833-10

303. Molina JM, Goguel J, Sarfati C, Michiels JF, Desportes-Livage I, Balkan S, Chastang C, Cotte L, Maslo C, Struxiano A, Derouin F, Decazes JM. Trial of oral fumagillin for the treatment of intestinal microsporidiosis in patients with HIV infection. AIDS 2000; 14: 1341-1348.

304. Lanternier F, Boutboul D, Menotti J, Chandesris MO, Sarfati C,
Mamzer Bruneel MF, Calmus Y, Mechaï F, Viard JP, Lecuit M, Bougnoux ME, Lortholary O. Microsporidiosis in solid organ transplant recipient: two Enterocytozoon bieneusi cases and review. Transpl Infect Dis 2009; 11: 83-88. https://doi.org/10.1111/ j.1399-3062.2008.00347.x

305. George B, Coates T, McDonald S, Russ G, Cherian S, Nolan J, Brealey J. Disseminated microsporidiosis with Encephalitozoon species in a renal transplant recipient. Nephrology 2012; 17 (suppl): 5-8. https://doi.org/10.1111/k.1440-1797.2012.01580.x

306. Boileau M, Ferreira J, Ahman I, Lavallee C, Qvarnstrom Y, Dufresne SF. Successful treatment of disseminated Anncalia algerae microsporidial infection with combination fumagillin and albendazole. Open Forum Infect Dis 2016; 3: 1-4. https://doi. org/10.1093/ofid/ofw158

307. Katiyar SK, Edlind TD. In vitro susceptibilities of the AIDS-associated microsporidian Encephalitozoon intestinalis to albendazole, its sulfoxide metabolite, and 12 additional benzimidazole derivatives. Antimicrob Agents Chemother 1997; 41: 27292732. https://doi.org/10.1128/AAC.41.12.2729

308. Morris DL, Smith PG. Albendazole in hydatid disease-hepatocellular toxicity. Trans R Soc Trop Med Hyg 1987; 81: 343-344. https://doi.org/10.1016/0035-9203(87)90259-8

309. Todorov T, Vutova K, Petkov D, Mechkov G, Kolev K. Albendazole treatment of human cystic echinococcosis. Trans R Soc Trop Med Hyg 1987; 81: 343-344. https://doi.org/10.1016/0035-9203 (88)90161-7

310. Yildiz BO, Haznedaroglu I, Cöplü L. Albendazole-induced amegakaryocytic thrombocytopenic purpura. Ann Pharmacol 1998; 32: 842. https://doi.org/10.1345/aph.17433

311. Polat C, Dervisoglu A, Hokelek M, Yetim I, Buyukkarabacak Y, Ozkutuk Y, Erzurumlu K. Dual treatment of albendazole in hepatic hydatidosis: new therapeutic modality in 52 cases. J Gastroenterol Hepatol 2005; 20: 421-425. https://onlinelibrary.wiley.com/doi/abs/10.1111/j.1440-1746.2004.03535.x

312. Ben Fredj N, Chaabane A, Chadly Z, Ben Fadhel N, Boughattas NA, Aouam K. Albendazole-induced associated acute hepatitis and bicytopenia. Scand J Infect Dis 2014; 46: 149-151. https:// doi.org/10.3109/00365548.2013.835068

313. Pourgholami MH, Szwajcer M, Chin M, Liauw W, Seef J, Galettis P, Morris DL, Links M. Phase I clinical trial to determine maximum tolerated dose of oral albendazole in patients with advanced cancer. Cancer Chemother Pharmacol 2010; 65: 597-605. https://doi.org/10.1007/s00280-009-1157-8

314. Kim MK, Park HW, Kim WJ, Park CM, Hong JY, Cho SJ, Jang MK. A case of acute drug-induced hepatotoxicity after albendazole treatment. Korean J Intern Med 2008; 75: 564-568 (in Korean). https://www.ekjm.org/journal/view.php?number=18621

315. Choi GY, Yang HW, Cho SH, Kang DW, Go H, Lee WC, Lee YJ, Jung SH, Kim AN, Cha SW. Acute drug-induced hepatitis caused by albendazole. J Korean Med Sci 2008; 23: 903-905. https://doi.org/10.3346/jkms.2008.23.5.903-5

316. Marin Zuluaga JI, marin Castro AE, Perez Cadavid JC, Restrepo Guttierez JC. Albendazole-induced granulomatous hepatitis: a case re- 
port. J Med Case Rep 2013; 7: 201. https://doi.org/10.1186/17521947-7-201

317. Bilgic Y, Yilmaz C, Cagin YF, Atayan Y, Karadag N, Harputluoglu MMM. Albendazole induced recurrent acute toxic hepatitis: a case report. Acta Gastro-enterol Belg 2017; 80: 309-311. https:// www.ageb.be/Articles/Volume\%2080\%20(2017)/Fasc2/11-Bilgic.pdf

318. Narciso-Schiavon JL, Delziovo HA, Santos LEB, Shiozawa MBC, Schiavon LL. Recurrent albendazole-induced acute hepatitis. Rev Colomb Gastroenterol 2018; 33: 463-467 (in Spanish). https://doi.org/10.22516/25007440.206

319. Amoruso C, Fuoti M, Miceli V, Zito E, Celano MR, De Giorgi A, Nebbia G. Acute hepatitis as a side effect of albendazole: a pediatric case. Pediatr Med Chir2009; 31: 176-178 (in Italian). https://europepmc.org/article/med/19839402

320. Nandi M, Sarkar S. Albendazole-induced recurrent hepatitis. Indian Pediatr 2013; 50: 1064. https://www.indianpediatrics. net/nov2013/1064-1065.pdf

321. Shah C, Mahapatra A, Shukla A, Bhatia S. Recurrent acute hepatitis caused by albendazole. Trop Gastroenterol 2013; 34: 3839. http://dx.doi.org/10.7869/tg.2012.90

322. Grama A, Aldea CO, Burac L, Delean D, Bulata B, Sirbe C, Duca E, Boghitoiu D, Coroleuca A, Pop TL. Etiology and outcome of acute liver failure in children-The experience of a single tertiary care hospital from Romania. Children 2020; 7: 282. https://doi.org/10.3390/children7120282

323. Batzlaff CM, Pupaibool J, Sohail MR. Acute renal failure associated with albendazole therapy in a patient with trichinosis. BMJ Case Rep 2014; 2014: bcr2013200668. https://doi.org/10.1136/ bcr-2013-200668

324. Tolomeo M, Colomba C, Meli M, Cascio A. Hepatotoxicity caused by mebendazole in a patient with Gilbert's syndrome. J Clin Pharm Ther 2019; 44: 985-987. https://doi.org/10.1111/ jcpt.13033

325. Seitz R, Schwerk W, Arnold R. Hepatocellular drug reaction caused by mebendazole therapy in cystic echinococcosis. $\mathrm{Z}$ Gastroenterol 1983; 21: 324-329 (in German). https://europepmc.org/article/med/6613213

326. Bekhti A, Pirotte J. Hepatotoxicity of mebendazole. Relationship with serum concentrations of the drug. Gastroenterol Clin Biol 1987; 11: 701-703. https://europepmc.org/article/med/ 3692093

327. Miskovitz PF, Javitt NB. Leukopenia associated with mebendazole therapy of hydatid disease. Am J Trop Med Hyg 1980; 29: 1356-1358. https://doi.org/10.4269/ajtmh.1980.29.1356

328. Chen KT, Twu SJ, Chang HJ, Lin RS. Outbreak of Stevens-Johnson syndrome/toxic epidermal necrolysis associated with mebendazole and metronidazole use among Filipino laborers in Taiwan. Am J Public Health 2003; 93: 489-492. https://doi. org/10.2105/ajph.93.3.489

329. Kwa MSG, Veenstra JG, Roos MH. Benzimidazole resistance in Haemonchus contortus is correlated with a conserved mutation at amino acid 200 in $\beta$-tubulin isotype 1. Mol Biochem Parasitol 1994;
63: 299-303. https://doi.org/10.1016/0166-6851(94)90066-3

330. De Clercq D, Sacko M, Behnke J, Gilbert F, Dorny P, Vercruysse J. Failure of mebendazole in treatment of human hookworm infections in the southern region of Mali. Am J Trop Med Hyg 1997; 57: 25-30. https://doi.org/10.4269/ajtmh.1997.57.25

331. Furtado LVF, Bello ACP, dos Santos HA, Carvalho MRS, Rabelo ÉML. First identification of the F200Y SNP in the $\beta$-tubulin gene linked to benzimidazole resistance in Ancylostoma caninum. Vet Parasitol 2014; 206: 313-316. https://doi.org/10.1016/ j.vetpar.2014.10.021

332. Jaeger LH, Carvalho-Costa FA. Status of benzimidazole resistance in intestinal nematode populations of livestock in Brazil: a systematic review. BMC Vet Res 2017; 13: 358. https://doi. org/10.1186/s12917-017-1282-2

333. Furtado LFV, de Aguiar PHN, Zuccherato LW, Teixeira TTG, Alves WP, da Silva VJ, Gasser RB, Rabelo ÉML. Albendazole resistance induced in Ancylostoma ceylanicum is not due to single-nucleotide polymorphisms (SNPs) at codons 167, 198, or 200 of the betatubulin gene, indicating another resistance mechanism. Parasitol Res 2019; 118: 837-849. https://doi.org/10.1007/s00436-01906218-9

334. Geerts S, Gryseels B. Anthelmintic resistance in human helminths: a review. Trop Med Int Health 2001; 6: 915-921. https:// doi.org/10.1046/j.1365-3156.2001.00774.x

335. Albonico M, Wright V, Bickle Q. Molecular analysis of the $\beta$-tubulin gene of human hookworms as a basis for possible benzimidazole resistance on Pemba Island. Mol Biochem Parasitol 2004; 134: 281-284. https://doi.org/10.1016/j.molbiopara. 2003.12.008

336. Bennett A, Guyatt H. Reducing intestinal nematode infections: efficacy of albendazole and mebendazole. Parasitol Today 2000; 16: 71-74. https://doi.org/10.1016/S0169-4758(99)01544-6

337. Albonico M, Bickle Q, Ramsan M, Montresor A, Savioli L, Taylor M. Efficacy of mebendazole and levamisole alone or in combination against intestinal nematode infections after repeated targeted mebendazole treatment in Zanzibar. Bull World Health Organ 2003; 81: 343-352. https://www.scielosp. org/article/bwho/2003.v81n5/343-352/en/

338. Flohr C, Tuyen L, Lewis S, Minh TT, Campbell J, Britton J, Williams H, Hien TT, Farrar J, Quinnell RJ. Low efficacy of mebendazole against hookworm in Vietnam: two randomized controlled trials. Am J Trop Med Hyg 2007; 76: 732-736. https:// doi.org/10.4269/ajtmh.2007.76.732

339. Humphries D, Mosites E, Otchere J, Twum WA, Woo L, JonesSanpei H, Harrison LM, Bungiro RD, Benham-Pyle B, Bimi L, Edoh D, Bosompem K, Wilson M, Cappello M. Epidemiology of hookworm infection in Kintampo North Municipality, Ghana: patterns of malaria coinfection, anemia, and albendazole treatment failure. Am J Trop Med Hyg 2011; 84: 792-800. https://doi.org/10.4269/ajtmh.2011.11-0003

340. Diawara A, Drake LJ, Suswillo RR, Kihara J, Bundy DAP, Scott ME, Halpenny C, Stothard JR, Prichard RK. Assays to detect $\beta$-tubulin codon 200 polymorphism in Trichuris trichiura and 
Ascaris lumbricoides. PLoS Negl Trop Dis 2009; 3: e397. https:// doi.org/10.1371/journal.pntd.0000397

341. Diawara A, Halpenny C, Churcher TS, Mwandawiro C, Kihara J, Kaplan RM, Streit TG, Idaghdour Y, Scott ME, Basáñez MG, Prichard RK. Association between response to albendazole treatment and $\beta$-tubulin frequencies in soil-transmitted helminths. PLoS Negl Trop Dis 2013; 7: e2247. https://doi.org/10.1371/ journal.pntd.0002247

342. Vercruysse J, Behnke JM, Albonico M, Ame SM, Angebault $C$, Bethony JM, Engels D, Guillard B, Nguyen TV, Kang G, Kattula D, Kotze AC, McCarthy JS, Mekonnen Z, Montresor A, Periago MV, Sumo L, Tchuenté LA, Dang TC, Zeynudin A, Levecke B. Assessment of the anthelmintic efficacy of albendazole in school children in seven countries where soil-transmitted helminths are endemic. PLoS Negl Trop Dis 2011; 5: e948. https:// doi.org/10.1371/journal.pntd.0000948

343. Schwab AE, Boakye DA, Kyelem D, Prichard RK. Detection of benzimidazole resistance-associated mutations in the filarial nematode Wuchereria bancrofti and evidence for selection by albendazole and ivermectin combination treatment. Am J Trop Med Hyg 2005; 73: 234-238. https://doi.org/10.4269/ajtmh. 2005.73.234

344. Upcroft J, Mitchell R, Chen N, Upcroft P. Albendazole resistance in Giardia is correlated with cytoskeletal changes but not with a mutation at amino acid 200 in $\beta$-tubulin. Microb Drug Resist 1996; 2: 303-308. https://doi.org/10.1089/mdr.1996.2.303

345. Lacey E, Watson TR. Activity of benzimidazole carbamates against L1210 mouse leukaemia cells: correlation with in vitro tubulin polymerization assay. Biochem Pharmacol 1985; 34: 3603-3605. https://doi.org/10.1016/0006-2952(85)90742-7

346. Rolin S, Amri HS, Batt AM, Levy M, Bagrel D, Siest G. Study of the in vitro bioactivation of albendazole in human liver microsomes and hepatic cell lines. Cell Biol Toxicol 1989; 5: 1-14. https://doi.org/10.1007/BF00141060

347. Pourgholami MH, Cai ZY, Lu Y, Wang L, Morris DL. Albendazole; a potent inhibitor of vascular endothelial growth factor and malignant ascites formation in OVCAR-3 tumor-bearing nude mice. Clin Cancer Res 2006; 12: 1928-1935. https://doi. org/10.1158/1078-0432.CCR-05-1181

348. Ehteda A, Galettis P, Pillai K, Morris DL. Combination of albendazole and 2-methoxyestradiol significantly improves the survival of HCT-116 tumor-bearing nude mice. BMC Cancers 2013; 13: 86. https://doi.org/10.1186/1471-2407-13-86

349. Javdan S, Nayeri H, Vaseghi G. Cytotoxic effect of albendazole on the breast cancer and melanoma. Zahedan J Res Med Sci 2018; 20: e9100. https://doi.org/10.5812/zjrms.9100

350. Priotti J, Baglioni V, García A, Rico MJ, Leonardi D, Lamas MC, Márquez MM. Repositioning of anti-parasitic drugs in cyclodextrin inclusion complexes for treatment of triple-negative breast cancer. AAPS PharmEciTech 2018; 19: 3734-3741. https://doi.org/10.1208/s12249-018-1169-y

351. Patel K, Doudican NA, Schiff PB, Orlow SJ. Albendazole sensitizes cancer cells to ionizing radiation. Radiat Oncol 2011; 6:
160. https://doi.org/10.1186/1748-717X-6-160

352. Cho YK, Shin EY, Uehara H, Ambati B. Antiangiogenesis effect of albendazole on the cornea. J Ocul Pharmacol Ther 2019; 35: 1-8. https://doi.org/10.1089/jop.2018.0103

353. Zhang X, Zhao J, Gao X, Pei D, Gao C. Anthelmintic drug albendazole arrests human gastric cancer cells at the mitotic phase and induces apoptosis. Exp Ther Med 2017; 13: 595603. https://doi.org/10.3892/etm.2016.3992

354. Yang MH, Ha IJ, Um JY, Ahn KS. Albendazole exhibits anti-neoplastic actions against gastric cancer cells by affecting STAT3 and SATAT5 activation by pleiotropic mechanism(s). Biomedicines 2021; 9: 362. https://doi.org/10.3390/biomedicines9040362

355. Ghasemi F, Black M, Vizeacoumar F, Pinto N, Ruicci KM, Le CCSH, Lowerison MR, Leong HS, Yoo J, Fung K, MacNeil D, Palma DA, Winquist E, Mymryk JS, Boutros PC, Datti A, Barrett JW, Nichols AC. Repurposing albendazole: new potential as a chemotherapeutic agent with preferential activity against HPV-negative head and neck squamous cell cancer. Oncotarget 2017; 8: 71512-71519. https://doi.org/10.18632/oncotarget.17292

356. Zhang QL, Lian DD, Zhu MJ, Li XM, Lee JK, Yoon TJ, Lee JH, Jiang $\mathrm{RH}$, Kim CD. Antitumor effect of albendazole on cutaneous squamous cell carcinoma (SCC) cells. BioMed Res Int 2019; 2019: 3689517. https://doi.org/10.1155/2019/3689517

357. Dogra N, Kumar A, Mukhopadhyay T. Fenbendazole acts as a moderate microtubule destabilizing agent and causes cancer cell death by modulating multiple cellular pathways. Sci Rep 2018; 8: 11926. https://doi.org/10.1038/s41598-018-30158-6

358. Movahedi F, Li L, Gu W, Xu ZP. Nanoformulations of albendazole as effective anticancer and antiparasite agents. Nanomedicine 2017; 12: 2555-2574. https://doi.org/10.2217/nnm-20170102

359. Racoviceanu R, Trandafirescu C, Voicu M, Ghiulai R, Borcan F, Dehelean C, Watz C, Aigner Z, Ambrus R, Coricovac DE, Cîrcioban D, Mioc A, Szuhanek CA, Şoica C. Solid polymeric nanoparticles of albendazole: synthesis, physico-chemical characterization and biological activity. Molecules 2020; 25: 5130. https://doi.org/10.3390/molecules25215130

360. Mukhopadhyay T, Sasaki J, Ramesh R, Roth JA. Mebendazole elicits a potent antitumor effect on human cancer cell lines both in vitro and in vivo. Clin Cancer Res 2002; 8: 2963-2969.

361. Sasaki J, Ramesh R, Chada S, Gomyo Y, Roth JA, Mukhopadhyay $\mathrm{T}$. The anthelmintic drug mebendazole induces mitotic arrest and apoptosis by depolymerizing tubulin in non-small cell lung cancer cells. Mol Cancer Therapeut 2002; 1: 1201-1209. https://mct.aacrjournals.org/content/1/13/1211.full-text.pdf

362. Martarelli D, Pompei P, Baldi C, Mazzoni G. Mebendazole inhibits growth of human adrenocortical carcinoma cell lines implanted in nude mice. Cancer Chemother Pharmacol 2008; 61: 809-817. https://doi.org/10.1007/s00280-007-0538-0

363. Doudican N, Rodriguez A, Osman I, Orlow SJ. Mebendazole induces apoptosis via Bcl-2 inactivation in chemoresistant melanoma cells. Mol Cancer Res 2008; 6: 1308-1315. https://doi. org/10.1158/1541-7786.MCR-07-2159 
364. Bai RY, Staedtke V, Aprhys CM, Gallia GL, Riggins GJ. Antiparasitic mebendazole shows survival benefit in 2 preclinical models of glioblastoma multiforme. Neuro-Oncology 2011; 13: 974-982. https://doi.org/10.1093/neuonc/nor077

365. Nygren P, Fraknäs M, Ågerup B, Larsson R. Repositioning of the anthelmintic drug mebendazole for the treatment for colon cancer. J cancer Res Clin Oncol 2013; 139: 2133-2140. https:// doi.org/10.1007/s00432-013-1539-5

366. De Witt M, Gamble A, Hanson D, Markowitz D, Powell C, Dimassi SA, Atlas M, Boockvar J, Ruggieri R, Symons M. Repurposing mebendazole as a replacement for vincristine for the treatment of brain tumors. Mol Med 2017; 23: 50-56. https:// doi.org/10.2119/molmed.2017.00011

367. Lai SR, Castello SA, Robinson AC, Koehler JW. In vitro anti-tubulin effects of mebendazole and fenbendazole in canine glioma cells. Vet Comp Oncol 2017; 15: 1445-1454. https://doi.org/ 10.1111/vco.12288

368. Elayapillai S, Ramraj S, Benbrook DM, Bieniasz M, Wang L, Pathuri G, Isingizwe ZR, Kennedy AL, Zhao YD, Lightfoot S,
Hunsucker LA, Gunderson CC. Potential and mechanism of mebendazole for treatment and maintenance of ovarian cancer. Gynecol Oncol 2021; 160: 302-311. https://doi.org/10.1016/ j.ygyno.2020.10.010

369. Rushworth LK, Hewit K, Munnings-Tomes S, Somani S, James D, Shanks E, Dufes C, Straube A, Patel R, Leung HY. Repurposing screen identifies mebendazole as a clinical candidate to synergise with docetaxel for prostate cancer treatment. Br J Cancer 2020; 122: 517-527. https://doi.org/10.1038/s41416019-0681-5

370. Dobrosotskaya IY, Hammer GD, Schteingart DE, Maturen KE, Worden FP. Mebendazole monotherapy and long-term disease control in metastatic adrenocortical carcinoma. Endocr Pract 2011; 17: e59-e62. https://doi.org/10.4158/EP10390.CR

371. Nygren P, Larsson R. Drug repositioning from bench to bedside: tumor remission by the antihelmintic drug mebendazole in refractory metastatic colon cancer. Acta Oncol 2014; 53: 427428. https://doi.org/10.3109/0284186X.2013.844359 
